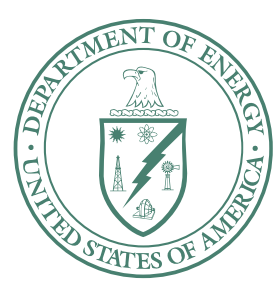

U.S. Department of Energy

Idaho Operations Office

\title{
Long-Term Ecological Monitoring Field Sampling Plan for 2007
}

July 2007 
DOE/ID-11316

Revision 1

Project No. 23368

\title{
Long-Term Ecological Monitoring Field Sampling Plan for 2007
}

\author{
Thomas Haney \\ Robin VanHorn
}

July 2007

Prepared for the 


\section{ABSTRACT}

This field sampling plan describes the field investigations planned for the Long-Term Ecological Monitoring Project at the Idaho National Laboratory Site in 2007. This plan and the Quality Assurance Project Plan for Waste Area Groups 1, 2, 3, 4, 5, 6, 7, 10, and Removal Actions constitute the sampling and analysis plan supporting long-term ecological monitoring sampling in 2007. The data collected under this plan will become part of the long-term ecological monitoring data set that is being collected annually. The data will be used to determine the requirements for the subsequent long-term ecological monitoring.

The primary goals of this plan, in coordination with other Idaho National Laboratory monitoring plans, include the following:

- $\quad$ Verifying that the remedial objectives specified in Idaho National Laboratory Site Comprehensive Environmental Response, Compensation, and Liability Act records of decision are maintained for ecological receptors

- $\quad$ Determining that legacy contamination in Idaho National Laboratory Site soil and water does not have unacceptable long-term Sitewide ecological impacts

- $\quad$ Identifying and quantifying adverse ecological effects, if any, resulting from Idaho National Laboratory Site contamination

- $\quad$ Providing information to support the selection and evaluation of appropriate ecological indicators for long-term monitoring.

This plan guides the 2007 investigations, including sampling, quality assurance, quality control, analytical procedures, and data management. As such, this plan will help to ensure that the resulting monitoring data will be scientifically valid, defensible, and of known and acceptable quality.

The areas under investigation include the Auxiliary Reactor Area, the Power Burst Facility, the Stationary Low Power Reactor area, the Boiling Water Reactor Experiment, the Experimental Breeder Reactor-1, the Naval Reactors Facility, the on-Site terrestrial reference area, and the off-Site aquatic reference area. Analytical and effects data will be collected during the 2007 field activities. Analytical data collection will include biotic (e.g., mice) and abiotic (e.g., soil) samples. Effects data will range from vegetative cover and small mammal population surveys to histopathic studies of mice. 


\section{CONTENTS}

ABSTRACT iii

ACRONYMS ix

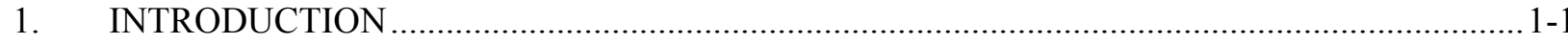

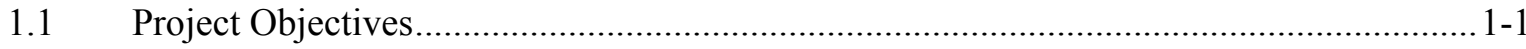

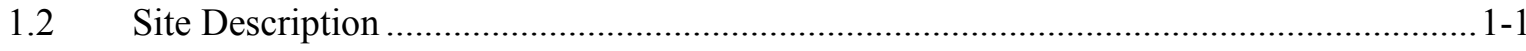

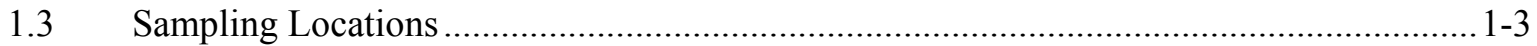

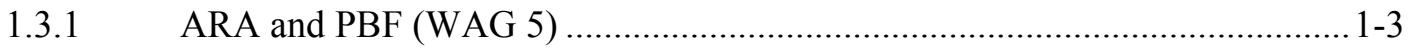

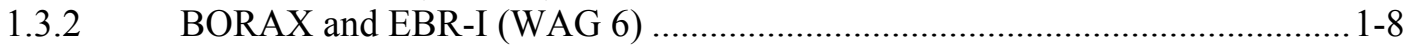

1.3.3 Naval Reactors Facility (WAG 8) ............................................................ 1-13

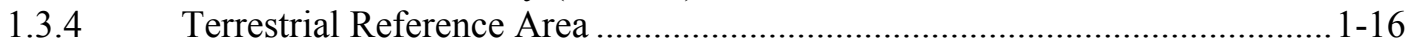

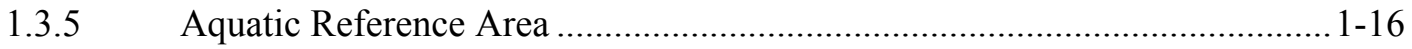

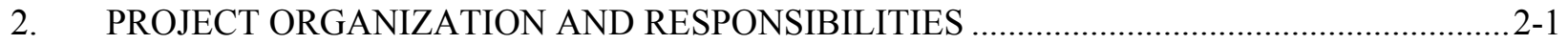

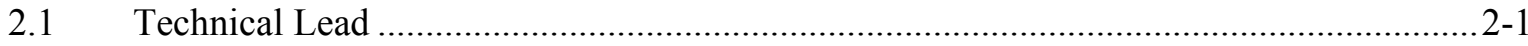

$2.2 \quad$ Waste Generator Services Waste Technical Specialist ..................................................2-1

2.3 Sample and Analysis Management Personnel .............................................................2-2

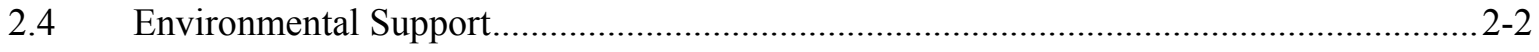

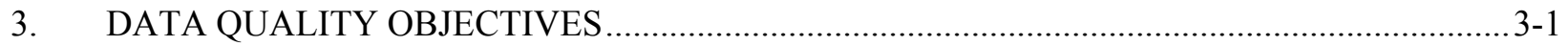

4. SAMPLE COLLECTION, ANALYSIS, AND DATA MANAGEMENT ….............................. $4-1$

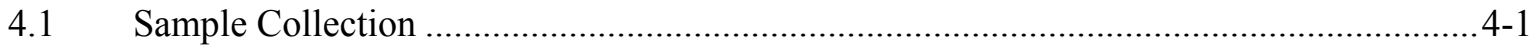

4.1.1 Presampling Meeting ........................................................................

4.1.2 Sampling and Analysis Requirements....................................................... 4-1

4.1.3 Sample Documentation and Management..................................................... 4-6

4.1.4 Sampling Equipment, Calibration, and Setup ........................................ 4-6

4.1.5 Sample Designation and Labeling.............................................................. $4-8$

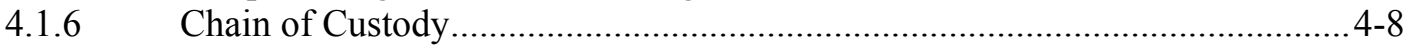

4.1.7 Sample Collection Procedures ................................................................ 4-8

4.1.8 Equipment Decontamination Procedures …................................................. 4-9

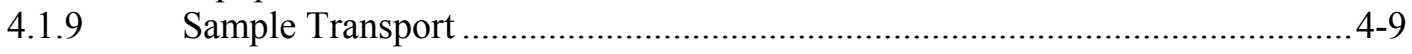

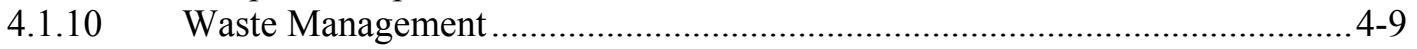




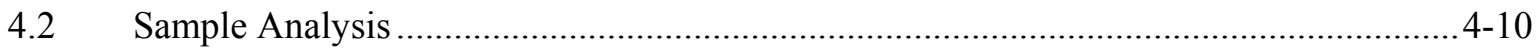

4.2.1 Analytical Methods ........................................................................... 4-10

4.2.2 Instrument Calibration Procedures........................................................... 4-11

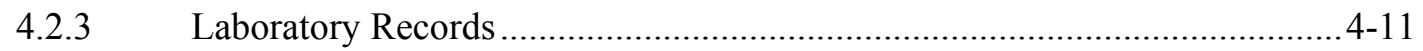

4.3 Data Management and Document Control .............................................................. 4-11

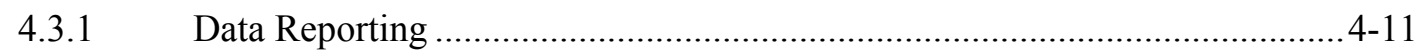

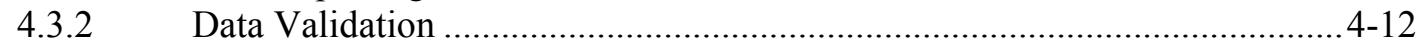

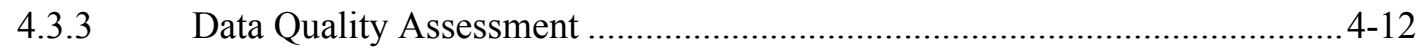

4.3.4 Final Characterization Report ........................................................... $4-12$

4.3.5 Document Control ............................................................................. $4-12$

5. HEALTH AND SAFETY REQUIREMENTS....................................................................

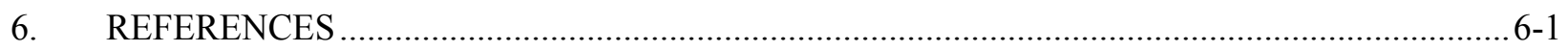

Appendix A-Sampling and Analysis Plan Tables ...................................................................... A-1

Appendix B-Sample Collection Procedures .................................................................................... B-1

\section{FIGURES}

1-1. Map of the INL Site showing locations of major facilities and sampling areas........................... 1-2

1-2. Map showing the ARA and general locations of the five sampling plots ................................... 1-9

1-3. Map showing the PBF and general locations of the five sampling plots ...................................1-10

1-4. Map of the BORAX and EBR-I showing randomly selected sampling grids ............................ 1-11

1-5. Map showing the location of the NRF sampling grids.....................................................1-17

1-6. Map showing the location of Terrestrial Reference Area 1 ................................................. 1-18

1-7. Map showing the location of Terrestrial Reference Area 2 .................................................. 1-19

1-8. Map showing the location of Chilly Slough, the aquatic reference area ................................... 1-20 


\section{TABLES}

1-1. Sampling activities by sampling area planned for 2007 .

1-2. General contaminants of potential concern summarized from the Sitewide ecological risk

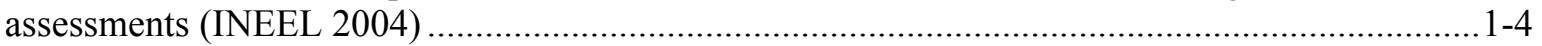

1-3. Analytes, requested quantitation levels, and analytical method............................................... 1-6

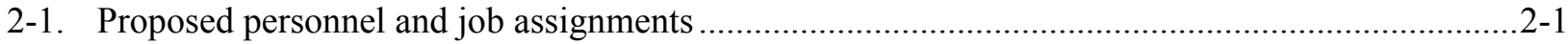

3-1. Data quality objectives for 2007 long-term ecological monitoring …...................................... 3-1

4-1. Composite biotic and collocated soil samples at BORAX and EBR-I for analytical

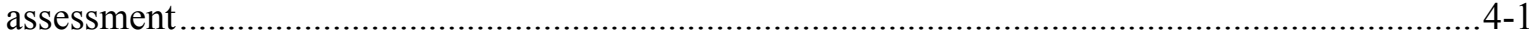

4-2. Composite biotic and collocated soil samples at the ARA for analytical assessment.....................4-2

4-3. Composite biotic and collocated soil samples at the PBF for analytical assessment ......................4-2

4-4. Composite biotic and collocated soil samples at the NRF for analytical assessment .....................4-3

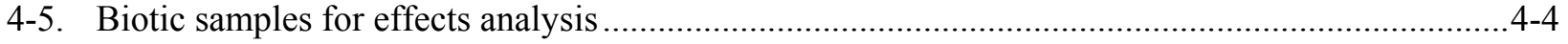

4-6. Biotic samples at the Terrestrial Reference Area for effects analysis.........................................4-4

4-7. Biased composite biotic and collocated samples at the Aquatic Reference Area for analytical assessment

4-8. Equipment and supplies list 


\section{ACRONYMS}

$\mathrm{AA}$

AOC

ARA

CERCLA

BORAX

CFR

COC

COPC

DOE

DOE-ID

DQO

DRF

DS

EBR-I

EPA

FSP

FTL

GDE

GPS

HAZWOPER

ICDF

ICP

INEEL

INL

JSA

LTEM

MCP alternative action

area of contamination

Auxiliary Reactor Area

Comprehensive Environmental Response, Compensation, and Liability Act

Boiling Water Reactor Experiment

Code of Federal Regulations

chain of custody

contaminant of potential concern

U.S. Department of Energy

U.S. Department of Energy Idaho Operations Office

data quality objective

Document Revision Form

decision statement

Experimental Breeder Reactor I

U.S. Environmental Protection Agency

field sampling plan

field team leader

guide

global positioning system

hazardous waste operations and emergency response

Idaho CERCLA Disposal Facility

Idaho Cleanup Project

Idaho National Engineering and Environmental Laboratory

Idaho National Laboratory (formerly INEEL)

job safety analysis

long-term ecological monitoring

management control procedure 


$\begin{array}{ll}\text { NA } & \text { not applicable } \\ \text { NRF } & \text { Naval Reactors Facility } \\ \text { NRTS } & \text { National Reactor Testing Station } \\ \text { PBF } & \text { Power Burst Facility } \\ \text { PLN } & \text { plan } \\ \text { PPE } & \text { personal protective equipment } \\ \text { PRD } & \text { program requirements document } \\ \text { QAPjP } & \text { Quality Assurance Project Plan } \\ \text { SAM } & \text { Sample and Analysis Management } \\ \text { SOW } & \text { statement of work } \\ \text { SPERT } & \text { Special Power Excursion Reactor Test } \\ \text { T/E } & \text { threatened/endangered } \\ \text { TEM } & \text { template } \\ \text { TPR } & \text { technical procedure } \\ \text { USFWS } & \text { U.S. Fish and Wildlife Service } \\ \text { WAG } & \text { waste area group } \\ \text { WGS } & \text { Waste Generator Services } \\ & \end{array}$




\title{
Long-Term Ecological Monitoring Field Sampling Plan for 2007
}

\author{
1. INTRODUCTION
}

This field sampling plan (FSP) was prepared for the Long-Term Ecological Monitoring (LTEM) Project of the Idaho Cleanup Project (ICP) at the Idaho National Laboratory (INL) Site. In identifying the sampling and analysis activities for LTEM in 2007, this plan was prepared according to the requirements outlined in ICP Management Control Procedure (MCP) -9439, "Environmental Sampling Activities at the INL"; MCP-3562, "Hazard Identification, Analysis, and Control of Operational Activities"; and Template (TEM) -104, "Model for Preparation of Characterization Plans."

The areas of the INL Site to be investigated in 2007 include Waste Area Groups (WAGs) 5, 6, and 8. The WAG 5 sites include the Auxiliary Reactor Area (ARA) and Power Burst Facility (PBF) area; WAG 6 sites include the Boiling Water Reactor Experiment and Experimental Breeder Reactor-I (BORAX and EBR-I) area; and WAG 8 includes the Naval Reactors Facility (NRF), one on-Site terrestrial reference area, and one off-Site aquatic reference area.

Analytical and effects data will be collected during the 2007 field activities. Analytical data collections include biotic (e.g., mice) and abiotic (e.g., soil) samples. Effects data collections include evaluation of vegetation, invertebrate, mammal, and avian community structures and histopathic studies of mice.

\subsection{Project Objectives}

Under the Long-Term Ecological Monitoring Plan for the Idaho National Engineering and Environmental Laboratory (INEEL 2004), the objective of the LTEM Project is to assess ecological effects from contaminants that are covered under the Comprehensive Environmental Response, Compensation, and Liability Act (CERCLA) (42 USC $\S 9601$ et seq.). The LTEM plan approach, based on the results of the ecological risk assessment presented in the Comprehensive Remedial Investigation/Feasibility Study for Waste Area Groups 6 and 10 Operable Unit 10-04 (DOE-ID 2001), meets the requirements for Sitewide ecological monitoring set forth in the Record of Decision Experimental Breeder Reactor-I/Boiling Water Reactor Experiment Area and Miscellaneous Sites (DOE-ID 2002).

The Quality Assurance Project Plan for Waste Area Groups 1, 2, 3, 4, 5, 6, 7, 10, and Removal Actions (QAPjP) (DOE-ID 2006) governs Federal Facility Agreement and Consent Order for the Idaho National Engineering Laboratory (DOE-ID 1991) project work performed by INL Site employees, subcontractors, and employees of other companies or U.S. Department of Energy (DOE) laboratories.

In addition to the planned sampling, project leads may decide to move sample plots or collect opportunistic plant, soil, or small mammal samples within the areas selected for sampling this year if possible indicators (e.g., stained soil or mutated animals) of contaminant exposure are evident.

\subsection{Site Description}

The INL Site occupies approximately $2,305 \mathrm{~km}^{2}\left(890 \mathrm{mi}^{2}\right)$ of the northwestern portion of the eastern Snake River Plain (see Figure 1-1). The Snake River Plain is approximately $97 \mathrm{~km}$ (60 mi) wide and over $600 \mathrm{~km}$ (370 mi) long. Elevation averages approximately 1,524 m (5,000 ft). 


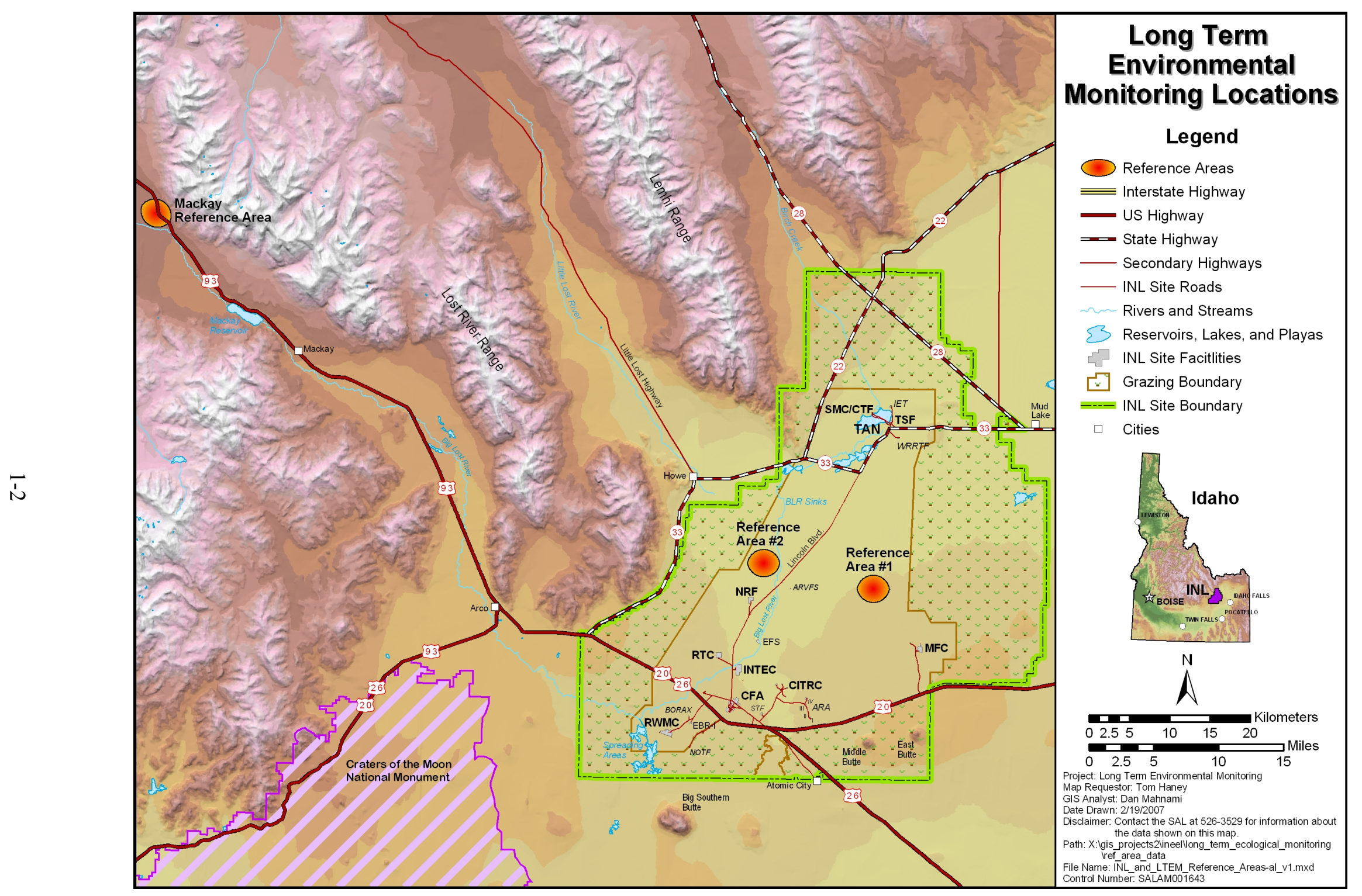

Figure 1-1. Map of the INL Site showing locations of major facilities and sampling areas. 
The INL Site is a semiarid desert with a mean annual precipitation of less than $22 \mathrm{~cm}(9 \mathrm{in}$.) and large daily and seasonal temperature variations. In winter, air temperatures may not rise above freezing for weeks, and the topsoil usually remains frozen from mid- to late November through early March. Snow cover typically persists for 2 to 3 months, but it is highly variable between years. During the summer, low humidity and clear skies result in relatively high maximum temperatures at 30 to $35^{\circ} \mathrm{C}\left(85\right.$ to $\left.95^{\circ} \mathrm{F}\right)$. At night, temperatures drop below $10^{\circ} \mathrm{C}\left(50^{\circ} \mathrm{F}\right)$.

The INL Site lies within the Eastern Snake River Plain, which is a low-relief volcanic province that formed in response to movement of the North American tectonic plate over the stationary hotspot that is located under Yellowstone National Park. Bordered by high mountains, the Eastern Snake River Plain is a high-desert basin containing basalt lava flows and various river, wind, and lake sediments. Large basin-and-range normal faults adjacent to the plain and basaltic volcanism on the plain are ongoing geologic processes that generate seismic and volcanic hazards for INL Site facilities. Hackett and Smith (1992) provide a detailed summary of the regional geologic history.

Sagebrush flats, basalt outcrops, and volcanic buttes help isolate the INL Site facilities and ecological habitats. The INL Site is bounded on the east and northwest by the Lost River and Lemhi Ranges and the mouths of the Big Lost River and Little Lost River Valleys. On the north the Site is bounded by the mouth of Birch Creek Valley and the southern tip of the Beaverhead Mountains of the Bitterroot Range. Because of this access, large numbers of raptors and mammals funnel onto the INL Site for wintering. In addition, because the INL Site border is secure and domestic grazing has been eliminated from the core area for more than 50 years, the Site has become a refuge for native plants and wildlife.

\subsection{Sampling Locations}

Yearly sampling refers to data types collected annually, although the locations at which data are collected vary. Table 2 of the LTEM Plan (INEEL 2004) provides the locations and suggested initial sampling year for each area of concern. As discussed, WAG 5 (ARA and PBF), WAG 8 (NRF), WAG 6 (BORAX and EBR-I) and reference areas have been identified for sampling in 2007.

Yearly sampling will be performed as discussed in the LTEM Plan (INEEL 2004) and in this FSP. The areas of concern and the sampling to be performed in 2007 are summarized in Table 1-1 and discussed below. Table 1-2 summarizes the contaminants of potential concern (COPCs) for each of the sites, while Table 1-3 summarizes the analytes, requested quantitation limits, and analytical methods.

\subsubsection{ARA and PBF (WAG 5)}

The Auxiliary Reactor Area (ARA) and the Power Burst Facility (PBF) compose WAG 5. The ARA consisted of four separate operational areas (designated as ARA-I, ARA-II, ARA-III, and ARA-IV). The ARA-II facility housed the Stationary Low Power Reactor No. 1 (SL-1) facility and numerous minor structures. The ARA-I facility was built to support SL-1. Both of these facilities were built in 1957. In 1961, an accident destroyed the SL-1 reactor, and ARA-I became the staging area for the SL-1 emergency response and subsequent SL-1 decontamination and cleanup. The SL-1 was a small nuclear power plant designed by Argonne National Laboratory to generate electric power and space heat for remote arctic installations. On the evening of January 3, 1961, the SL-1 reactor accidentally achieved a prompt critical nuclear reaction. The reactor vessel and building were severely damaged and highly contaminated, and a massive cleanup operation to dismantle and dispose of the reactor and building ensued. A burial ground was constructed near ARA-II to minimize radiation exposure to the public and site workers during cleanup operations. Approximately $2,690 \mathrm{~m}^{3}\left(95,000 \mathrm{ft}^{3}\right)$ of radioactively contaminated debris and soil were disposed of in the burial ground (Holdren, Filemyr, and Vetter 1995). 
Table 1-1. Sampling activities by sampling area planned for 2007.

\begin{tabular}{|c|c|c|c|c|c|}
\hline Tasks & $\begin{array}{l}\text { ARA and } \\
\text { PBF } \\
\text { (WAG 5) }\end{array}$ & $\begin{array}{l}\text { BORAX and } \\
\text { EBR-I } \\
\text { (WAG 6) }\end{array}$ & $\begin{array}{c}\mathrm{NRF}^{\mathrm{a}} \\
(\mathrm{WAG} 8)\end{array}$ & $\begin{array}{c}\text { Terrestrial } \\
\text { Reference } \\
\text { Area }\end{array}$ & $\begin{array}{c}\text { Aquatic } \\
\text { Reference } \\
\text { Area } \\
\end{array}$ \\
\hline \multicolumn{6}{|l|}{ Population data } \\
\hline Birds & $\mathrm{X}$ & $\mathrm{X}$ & $\mathrm{X}$ & $\mathrm{X}$ & $-^{b}$ \\
\hline Mammals & $\mathrm{X}$ & $\mathrm{X}$ & $\mathrm{X}$ & $\mathrm{X}$ & - \\
\hline Plants & $\mathrm{X}$ & $\mathrm{X}$ & $\mathrm{X}$ & $\mathrm{X}$ & - \\
\hline Reptiles & $X$ & $\mathrm{X}$ & $\mathrm{X}$ & $\mathrm{X}$ & - \\
\hline \multicolumn{6}{|l|}{ Analytical data } \\
\hline Soil & $\mathrm{X}$ & $\mathrm{X}$ & $\mathrm{X}$ & - & - \\
\hline Vegetation & $\mathrm{X}$ & $\mathrm{X}$ & $\mathrm{X}$ & - & - \\
\hline Mammal & $\mathrm{X}$ & $\mathrm{X}$ & $\mathrm{X}$ & - & - \\
\hline Water & - & - & $X^{a}$ & - & $\mathrm{X}$ \\
\hline Sediment & - & - & $\mathrm{X}^{\mathrm{a}}$ & - & $\mathrm{X}$ \\
\hline Aquatic plant & - & - & $\mathrm{X}^{\mathrm{a}}$ & - & $\mathrm{X}$ \\
\hline \multicolumn{6}{|l|}{ Effects data } \\
\hline Organ to body weight & $\mathrm{X}$ & $\mathrm{X}$ & $\mathrm{X}$ & $\mathrm{X}$ & - \\
\hline Histopathy & $\mathrm{X}$ & $\mathrm{X}$ & $\mathrm{X}$ & $\mathrm{X}$ & - \\
\hline Earthworm toxicity & $\mathrm{X}$ & $\mathrm{X}$ & $\mathrm{X}$ & $\mathrm{X}$ & - \\
\hline Seedling toxicity & $\mathrm{X}$ & $\mathrm{X}$ & $\mathrm{X}$ & $\mathrm{X}$ & - \\
\hline Disturbance ranking & $\mathrm{X}$ & $\mathrm{X}$ & $\mathrm{X}$ & $\mathrm{X}$ & - \\
\hline Soil & $\mathrm{X}$ & $\mathrm{X}$ & $\mathrm{X}$ & $X$ & - \\
\hline \multicolumn{6}{|c|}{$\begin{array}{l}\text { a. NRF (WAG 8): Sampling tasks are applicable to all NRF locations except the Industrial Waste Ditch where only water, } \\
\text { sediment, and aquatic plant sampling will be conducted. } \\
\text { b. }-=\text { not collected. } \\
\text { ARA = Auxiliary Reactor Area } \\
\text { BORAX = Boiling Water Reactor Experiment } \\
\text { COPC = contaminant of potential concern } \\
\text { EBR-I = Experimental Breeder Reactor } \\
\text { NRF = Naval Reactors Facility } \\
\text { PBF = Power Burst Facility } \\
\text { WAG = Waste Area Group }\end{array}$} \\
\hline
\end{tabular}

Table 1-2. General contaminants of potential concern summarized from the Sitewide ecological risk assessments (INEEL 2004).

\begin{tabular}{ccccc}
\hline & COPC & $\begin{array}{c}\text { ARA/PBF } \\
\text { (WAG 5) }\end{array}$ & $\begin{array}{c}\text { NRF }^{\mathrm{a}, \mathrm{b}} \\
\text { (WAG 8) }\end{array}$ & $\begin{array}{c}\text { EBR-I/BORAX } \\
\text { (WAG 6) }\end{array}$ \\
\hline Inorganics $^{\text {Arsenic }}{ }^{\mathrm{d}}$ & $-^{\mathrm{c}}$ & - & - \\
Antimony $^{\mathrm{d}}$ & $\mathrm{X}$ & $\mathrm{X}$ & $\mathrm{X}$ \\
Barium $^{\text {Cadmium }}$ & $\mathrm{X}$ & - & $\mathrm{X}$ \\
Chromium (III) & - & - & - \\
& $\mathrm{X}$ & - & -
\end{tabular}


Table 1-2. (continued).

\begin{tabular}{|c|c|c|c|}
\hline $\mathrm{COPC}$ & $\begin{array}{l}\text { ARA/PBF } \\
\text { (WAG 5) }\end{array}$ & $\begin{array}{c}\mathrm{NRF}^{\mathrm{a}, \mathrm{b}} \\
(\mathrm{WAG} 8)\end{array}$ & $\begin{array}{l}\text { EBR-I/BORAX } \\
\text { (WAG 6) }\end{array}$ \\
\hline Chromium (VI) & - & - & - \\
\hline Cobalt & $X$ & - & - \\
\hline Copper & $\mathrm{X}$ & - & $\mathrm{X}$ \\
\hline Lead & $X$ & $\mathrm{X}$ & $\mathrm{X}$ \\
\hline Manganese & $\mathrm{X}$ & - & - \\
\hline Mercury & $\mathrm{X}$ & $\mathrm{X}$ & - \\
\hline Nickel & $X$ & - & - \\
\hline Selenium & $\mathrm{X}$ & - & - \\
\hline Silver & $\mathrm{X}$ & - & - \\
\hline Strontium & - & - & - \\
\hline Thallium & $\mathrm{X}$ & - & - \\
\hline Vanadium & $\mathrm{X}$ & - & - \\
\hline Zinc & $\mathrm{X}$ & - & $\mathrm{X}$ \\
\hline Organics & - & - & - \\
\hline $\begin{array}{l}\text { Polychlorinated biphenyls, including } \\
\text { Aroclors- } 1248,-1254 \text {, and }-1260^{\mathrm{e}}\end{array}$ & $X^{e}$ & - & - \\
\hline Total petroleum hydrocarbons & - & - & $\mathrm{X}$ \\
\hline Xylene $^{\mathrm{d}}$ & - & - & - \\
\hline Radionuclides ${ }^{\mathrm{f}}$ & - & - & - \\
\hline $\begin{array}{l}\text { Am-241, Co-60, Cs-134, Cs-137, Eu-152, } \\
\text { Eu-154, Nb-94, Pu-238, Pu-238, } \\
\text { Pu-239/240, Sr-90, U-235, U-238, and } \\
\text { tritium }\end{array}$ & $X$ & - & $X$ \\
\hline
\end{tabular}

a. Significant uncertainty exists in the screening-level ecological risk assessment (NRF 1997).

b. NRF (WAG 8): Even though radionuclides were eliminated as COPCs under a separate investigation, samples collected will be analyzed for radionuclides to ensure consistency among INL sites.

c. $-=$ not identified as a contaminant of concern.

d. Retained due to toxicity and common occurrence as a contaminant at CERCLA sites.

e. Retained due to environmental persistence and potential for bioaccumulation.

f. Radionuclides were retained due to common concern at the INL.

ARA $=$ Auxiliary Reactor Area

BORAX $=$ Boiling Water Reactor Experiment

$\mathrm{COPC}=$ contaminant of potential concern

EBR-I $=$ Experimental Breeder Reactor

$\mathrm{NRF}=$ Naval Reactors Facility

PBF $=$ Power Burst Facility

$\mathrm{WAG}=$ Waste Area Group 
Table 1-3. Analytes, requested quantitation levels, and analytical method.

\begin{tabular}{|c|c|c|c|c|}
\hline \multirow[b]{2}{*}{ Analyte $^{a}$} & \multicolumn{3}{|c|}{ Requested Quantitation Limit } & \multirow[b]{2}{*}{ Proposed Method } \\
\hline & $\begin{array}{c}\text { Soils } \\
\text { (mg/kg, } \mu \mathrm{g} / \mathrm{kg} \text {, } \\
\text { or } \mathrm{pCi} / \mathrm{g} \text { ) }\end{array}$ & $\begin{array}{c}\text { Biota } \\
(\mathrm{mg} / \mathrm{kg}, \mu \mathrm{g} / \mathrm{kg} \\
\text { or } \mathrm{pCi} / \mathrm{g} \text { ) }\end{array}$ & $\begin{array}{c}\text { Water } \\
(\mu \mathrm{g} / \mathrm{L} \text { or } \mathrm{pCi} / \mathrm{L})\end{array}$ & \\
\hline \multicolumn{5}{|l|}{ Inorganics $^{\mathrm{b}, \mathrm{c}}$} \\
\hline Antimony & 0.06 & 0.005 & 1.2 & SW-846 \\
\hline Arsenic & 0.7 & 0.03 & 5.0 & SW-846 \\
\hline Barium & 20.0 & 2.0 & 100.0 & SW-846 \\
\hline Beryllium & 0.5 & 0.05 & 5.0 & SW-846 \\
\hline Cadmium & 0.09 & 0.005 & 1.0 & SW-846 \\
\hline Chromium & 0.4 & 0.15 & 2.0 & SW-846 \\
\hline Cobalt & 5.0 & 0.01 & 50.0 & SW-846 \\
\hline Copper & 0.6 & 2.0 & 1.0 & SW-846 \\
\hline Lead & 0.3 & 0.05 & 1.0 & SW-846 \\
\hline Manganese & 1.5 & 1.5 & 10.0 & SW-846 \\
\hline Mercury & 0.01 & 0.01 & 0.1 & SW-846 \\
\hline Nickel & 4.0 & 0.5 & 20.0 & SW-846 \\
\hline Selenium & 0.035 & 0.01 & 3.0 & SW-846 \\
\hline Silver & 0.13 & 0.005 & 1.0 & SW-846 \\
\hline Strontium & 2.0 & 2.0 & 0.2 & SW-846 \\
\hline Thallium & 0.1 & 0.002 & 0.4 & SW-846 \\
\hline Vanadium & 5.0 & 0.09 & 40.0 & SW-846 \\
\hline Zinc & 2.0 & 2.0 & 20.0 & SW-846 \\
\hline \multicolumn{5}{|l|}{ Radionuclides $^{\mathrm{c}}$} \\
\hline Gamma emitters ${ }^{\mathrm{d}}$ & 0.1 & 0.1 & 0.1 & Gamma spectrometry \\
\hline Am-241 & 0.05 & 0.05 & 0.2 & Alpha spectroscopy \\
\hline Cs-134 and -137 & $<0.1$ & $<0.1$ & $<30$ & Gamma spectroscopy \\
\hline Co- 60 & $<0.1$ & $<0.1$ & $<30$ & Gamma spectroscopy \\
\hline Eu-152, -154 , and -155 & $<0.1$ & $<0.1$ & $<30$ & Gamma spectroscopy \\
\hline Pu-238, -239 , and $-239 / 240$ & 0.05 & 0.05 & 0.2 & Alpha spectroscopy \\
\hline Sr-90 & 0.5 & 0.5 & 1.0 & $\begin{array}{l}\text { Gas flow proportional } \\
\text { counting }\end{array}$ \\
\hline $\mathrm{U}-234,-235$, and -238 & 0.05 & 0.05 & 0.5 & Alpha spectroscopy \\
\hline $\begin{array}{l}\text { a. Required detection limits for all analy } \\
\text { b. High mineral concentrations and matr } \\
\text { Detection limits could be compromised } \\
\text { c. Double volume is needed for laborato } \\
\text { radionuclides (increased volume is requi } \\
\text { d. Limited sample size or low density for }\end{array}$ & $\begin{array}{l}\text { may be elevated if } \mathrm{d} \\
\text { omplexity could cau } \\
\text { lutions are needed. } \\
\text { uality control on rad } \\
\text { for one sample per } \\
\text { trixes other than so }\end{array}$ & $\begin{array}{l}\text { tions are needed due } \\
\text { dilutions to minimiz } \\
\text { chemistry parameter } \\
\text { samples). } \\
\text { could cause elevatec }\end{array}$ & $\begin{array}{l}\text { matrix interferences. } \\
\text { nterelement or matrix } \\
\text { nd triple volume is ne } \\
\text { tection limits for gan }\end{array}$ & $\begin{array}{l}\text { interference for metals analysis } \\
\text { eded for metals and } \\
\text { ma spectrometry. }\end{array}$ \\
\hline
\end{tabular}

ARA-III and ARA-IV were built in the late 1950s. The ARA-III facility initially housed the Army Gas-Cooled Reactor Experiment research reactor, and the ARA-IV facility was built to accommodate the Mobile Low Power Reactor-1. Experiments with the Army Gas-Cooled Reactor were discontinued at ARA-III in 1961. Work on the Mobile Low Power Reactor-1 at ARA-IV continued through 1964. In 1963, the ARA-III facility was modified to support tests at ARA-IV and remained active until 1965. ARA-IV was used to operate the Nuclear Effects Reactor Program from 1967 to 1970. ARA-IV is still in use as part of the Critical Infrastructure Test Range Complex. 
PBF was built in the late 1950s. Initially, it was known as the Special Power Excursion Reactor Test (SPERT) facility and consisted of five separate operational areas: the Control Area and SPERT-I, SPERT-II, SPERT-III, and SPERT-IV. Later, operational areas at PBF consisted of the PBF Control Area, the PBF Reactor Area (SPERT-I), the Waste Engineering Development Facility (SPERT-II), the Waste Experimental Reduction Facility (SPERT-III), and the Mixed Waste Storage Facility (SPERT-IV). Collectively, the Waste Engineering Development Facility, the Waste Experimental Reduction Facility, and the Mixed Waste Storage Facility were known as the Waste Reduction Operations Complex.

Operations at ARA and PBF resulted in releases of contaminants to the environment and were designated as WAG 5 under the Federal Facility Agreement and Consent Order (FFA/CO) (DOE-ID 1991).

1.3.1.1 Environmental Setting-ARA and PBF. ARA and PBF are located in the south-central portion of the INL approximately $50 \mathrm{mi}$ from the cities of Idaho Falls and Pocatello and $10 \mathrm{mi}$ east of the Central Facilities Area (CFA).

The ARA and PBF are located on the alluvial plain of the Big Lost River, where the topography of the area is relatively flat. Surface materials in the area consist mainly of fine-grained aeolian sediments, interspersed with subordinate alluvial sediments deposited by local run-off. Soils are characterized as sandy loams containing a high percentage of silt and a low percentage of clay (Olson, Jeppesen, and Lee 1995). The area is composed primarily of Malm-Bondfarm-Matheson Complex (432) soils and Coffee-Nargon-Atom (425) soils. The Malm-Bondfarm-Matheson Complex (432) consists of moderately deep, well-drained, sandy-loam soils on basalt plains. A calcic horizon is present at a depth of approximately $30 \mathrm{~cm}$ (12 in.). Permeability of these soils is moderately rapid, and the erosion hazards for these soils are slight to moderate. The Coffee-Nargon-Atom complex (425) consists of moderately deep to very deep, well-drained, silty clay loam soils on lava plains. Permeability of these soils is moderately slow to moderate, and the erosion hazards for these soils are slight to moderate. The area immediately surrounding PBF is composed of Grassy Butte loamy sand (34J) and Menan silt loam (41) soils. Grassy Butte soils are very deep and very well drained (high permeability). These soils are highly mobile in wind and hazards for water erosion are moderate. Menan soils are well drained with moderately low permeability, and the erosion hazard is slight.

Sagebrush/rabbitbrush is the predominant vegetation type. The dominant vegetation species within this community are the Wyoming big sagebrush (Artemisia tridentata ssp. wyomingensis) and green rabbitbrush (Chrysothamnus viscidiflorus). Grasslands present in the area consist primarily of wheatgrasses (Agropyron spp. and Elymus spp.), and many of the disturbed areas at PBF and ARA have little or no vegetation. Remaining lawns and ornamental vegetation are used by a number of species such as songbirds, raptors, rabbits, and mule deer.

Sagebrush communities surrounding the area typically support a number of species including sage grouse, sage sparrow, and pronghorn antelope. Rock outcroppings associated with these communities also provide habitat for species such as bats, wood rats (Neotoma cinerea), and species of concern such as the pygmy rabbit (Brachylagus idahoensis). Nearby grasslands serve as habitat for species including the western meadowlark (Sturnella neglecta) and mule deer (Odocoileus hemionus).

The U.S. Fish and Wildlife Service (USFWS) no longer maintains a candidate species (C2) listing but addresses former C2 species as species of concern (USFWS 1996). Avian threatened/endangered $(\mathrm{T} / \mathrm{E})$ species or species of concern (formerly $\mathrm{C} 2$ ) with a potential for occurrence in the vicinity include the peregrine falcon (Falco peregrinus), bald eagle (Haliaeetus leucocephalus), northern goshawk (Accipiter gentilis), ferruginous hawk (Buteo regalis), loggerhead shrike (Lanius ludovicianus), and burrowing owl (Athene cunicularia) (USFWS 1997). The bald eagle and peregrine falcon are federally listed species. The remaining avian species are species of concern (formerly $\mathrm{C} 2$ ). A geographic 
information system (GIS) analysis showed that no T/E or C2 raptor species nest sites have been recorded in the area (DOE-ID 1999). A review of data collected as part of regularly conducted breeding bird surveys for the area immediately surrounding the PBF facilities showed that ferruginous hawks, golden eagles (Aquila chrysaetos), and other raptors and loggerhead shrikes are commonly observed in the vicinity (Belthoff, Power, and Reynolds 1998). The ARA facilities are not encompassed by current INL breeding bird survey routes. Four mammalian species of concern potentially occur at or near the ARA or PBF. These include the pygmy rabbit, Townsend's Western big-eared bat (Corynorhinus townsendii), long-eared myotis (Myotis evotis), and small-footed myotis (Myotis ciliolabrum) (USFWS 1997). While the presence of the pygmy rabbit in the area has not been verified, appropriate habitat exists in surrounding areas (Gabler 1997).

1.3.1.2 Contaminants of Potential Concern-ARA and PBF. ARA and PBF contamination sites include soil contamination, leach and inactive evaporation ponds, tanks, and a burial ground. Radionuclides (e.g., Cs-137) and metals (e.g., arsenic) are the primary contaminants of potential concern (COPCs) at ARA and PBF. Table 1-2 shows the general COPCs at ARA and PBF. See Table 1-3 for the requested quantitation limits.

\subsubsection{Probable Transport Pathways and Sampling-ARA and PBF. Metals and} radionuclides can affect animals through skin contact, inhalation, and ingestion. Ecological receptors such as deer mice or cottontail rabbits are most likely to contact the contaminants during foraging and burrowing. Animals could ingest soil-absorbed contaminants during feeding, preening, and grooming. Plants and invertebrates could bioaccumulate contaminants, and, through the food web, other animals could be exposed indirectly by eating plants or invertebrates that have absorbed or adsorbed contaminants from soil. During high winds, animals could inhale and ingest particulates. Ingestion also could occur if animals consume plants or invertebrates that have contaminated dust on them.

1.3.1.4 Selection of Sampling Locations. ARA and PBF are some distance apart. Locations at ARA and PBF that have both good habitat and possible contamination, but are not too disturbed by roads or other facility activities, were gridded into $100-\times 100-\mathrm{m}(110-\times 110-\mathrm{yd})$ plots. Then at each area, five plots were chosen for sampling with a bias to sites that may have possible contamination (Figures 1-2 and 1-3).

\subsubsection{BORAX and EBR-I (WAG 6)}

EBR-I, now a National Historical Landmark, and the BORAX sites are located in the southwest portion of the INL approximately 2 mi south of U.S. Highway 20 (see Figure 1-4). BORAX and EBR-I sites are included under WAG 6 as delineated in the FFA/CO (DOE-ID 1991).

EBR-I was the first reactor built on the National Reactor Testing Station (NRTS), now called Idaho National Laboratory (INL). EBR-I's primary mission was to develop and test the concept of a nuclear breeder reactor. EBR-I ushered in a new era in nuclear history when it became the first reactor to generate useable amounts of electricity from nuclear energy. It accomplished this feat on December 20, 1951, by lighting four light bulbs. The next day, EBR-I's output was boosted to $100 \mathrm{~kW}(\mathrm{e})$. From that point until its decommissioning in 1964, EBR-I was able to generate all of the electricity for its building, which it often did. 


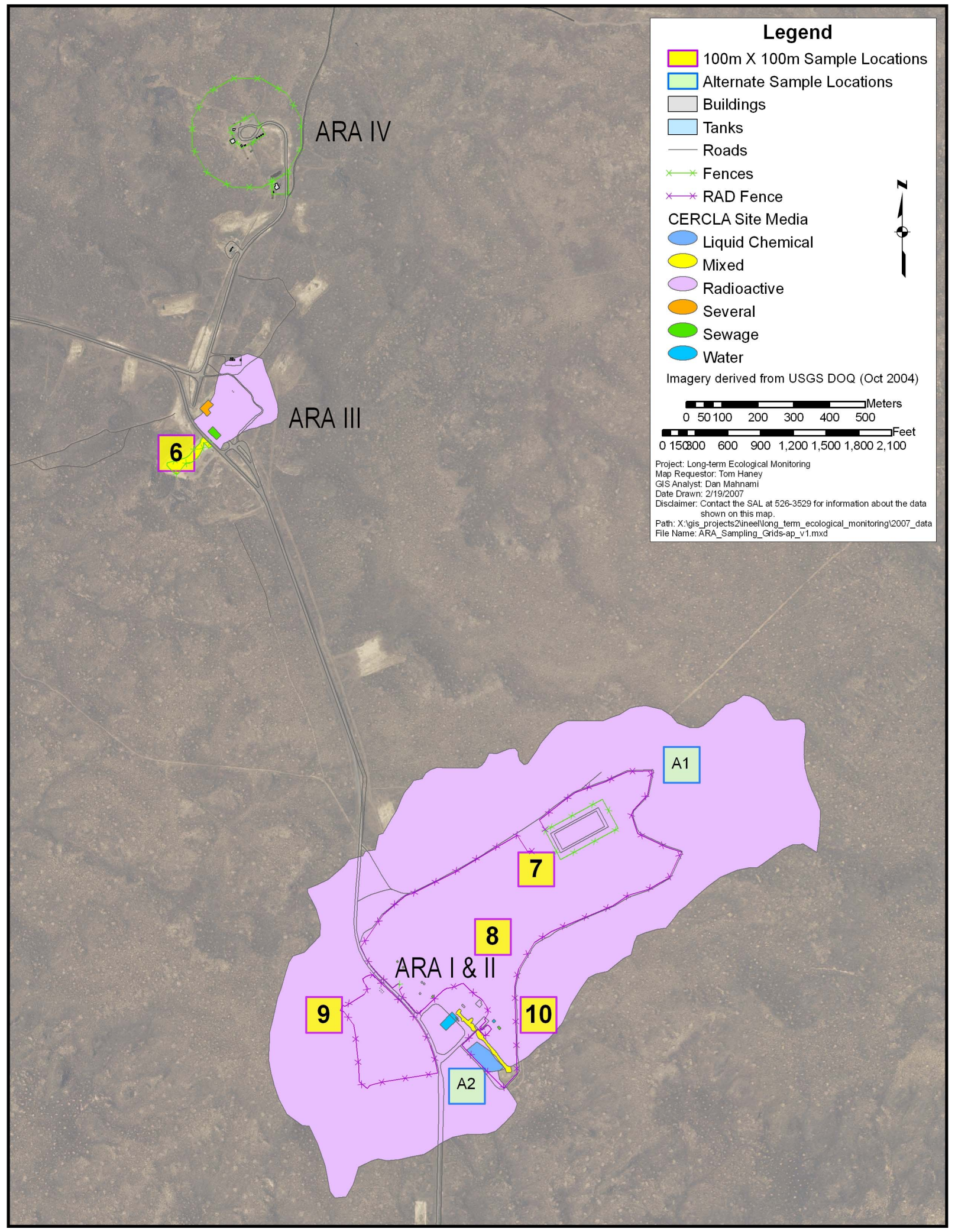

Figure 1-2. Map showing the ARA and general locations of the five sampling plots. 


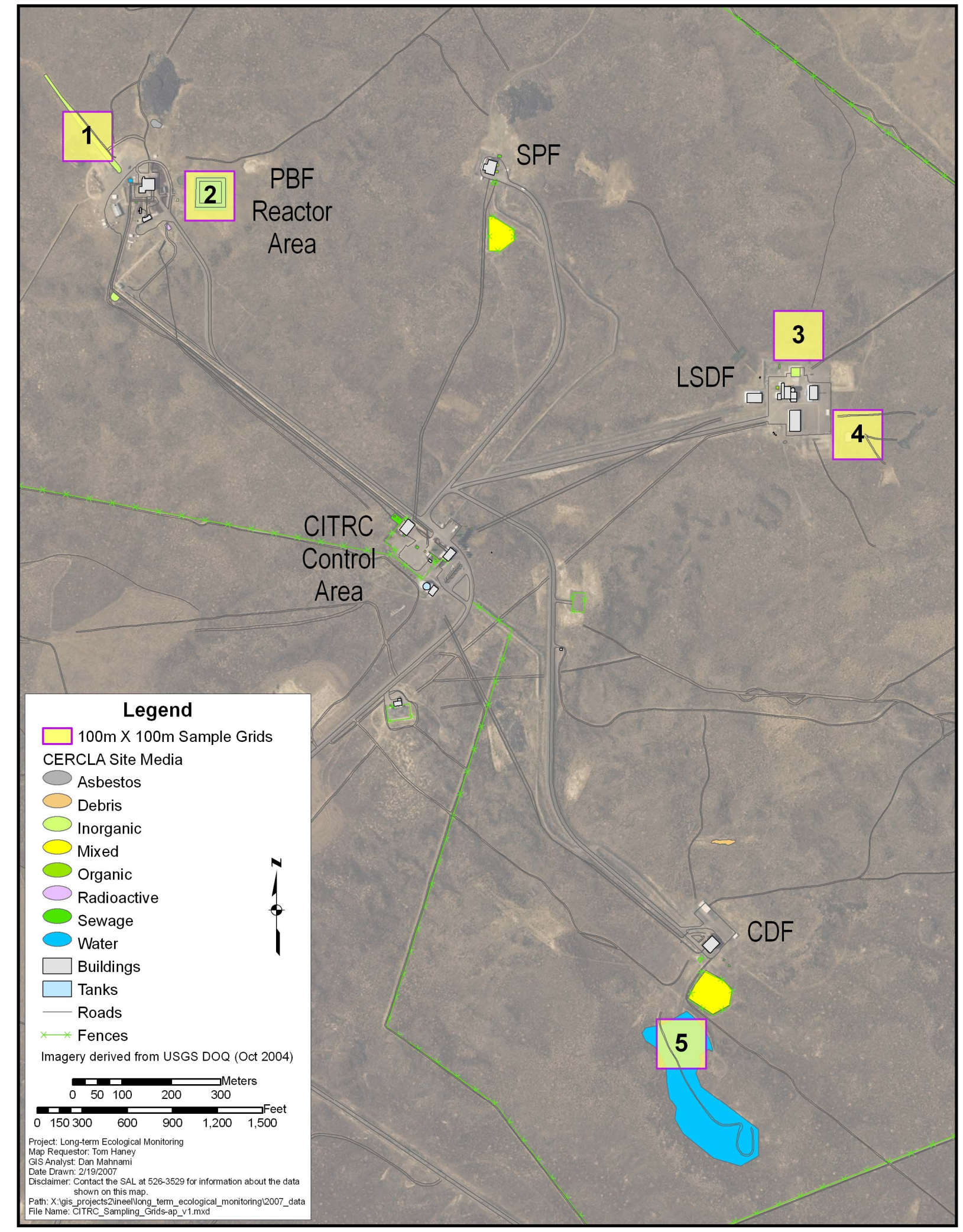

Figure 1-3. Map showing the PBF and general locations of the five sampling plots. 


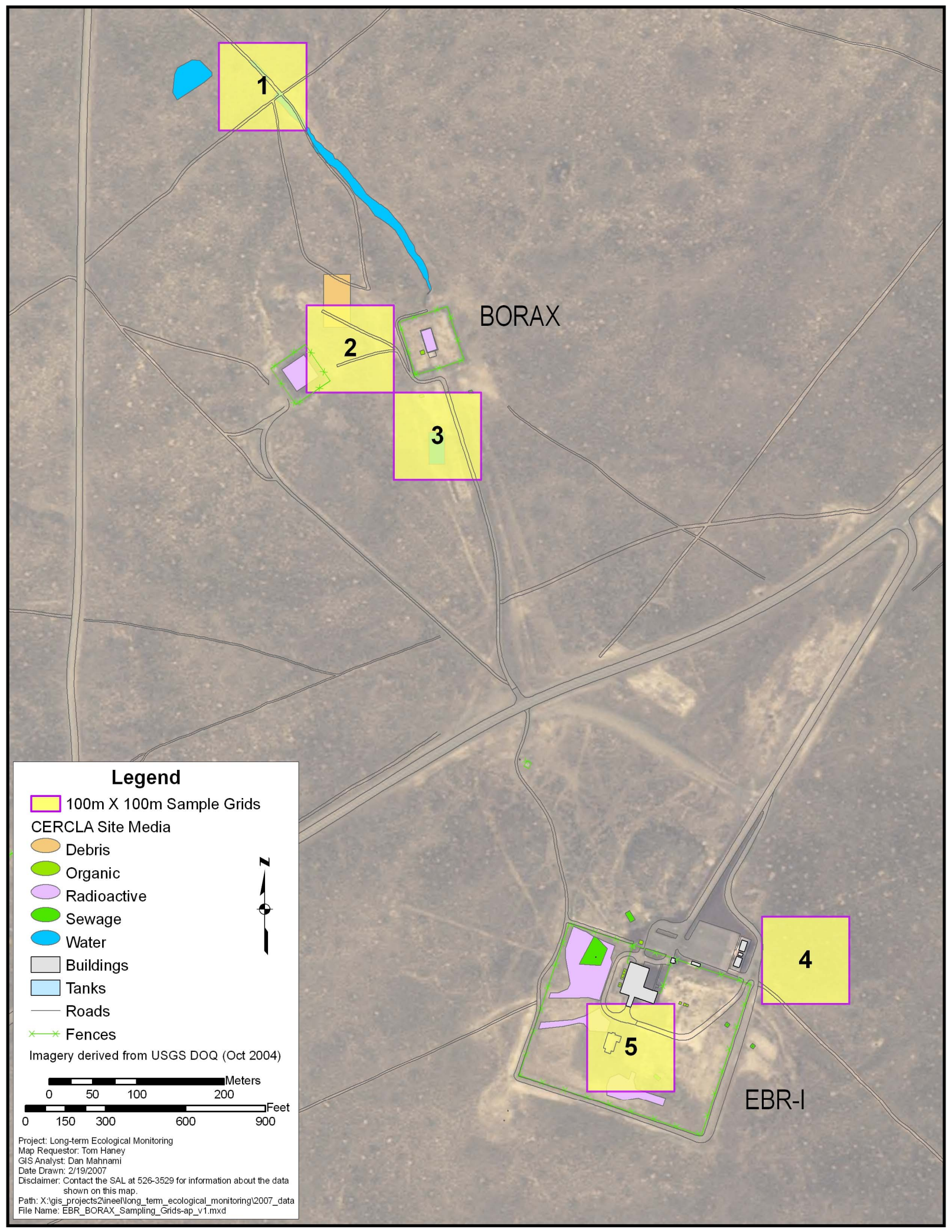

Figure 1-4. Map of the BORAX and EBR-I showing randomly selected sampling grids. 
On August 26, 1966, President Lyndon B. Johnson designated EBR-I as a Registered National Historic Landmark. In 1973, a plan was agreed upon to open EBR-I to the public. After thorough cleaning, decontamination, removal of materials, and other safeguarding of the facility, the EBR-I opened to the public for the first time on June 14, 1975. Two nuclear jet engines from the Aircraft Nuclear Propulsion program are displayed outside the EBR-I perimeter fence as part of the National Historical Landmark.

The BORAX facility, located approximately $0.75 \mathrm{mi}$ north of the EBR-I facility (see Figure 1-4), was the site of five (BORAX I, II, III, IV, and V) reactor experiments conducted between 1953 and 1964. BORAX-I was a small water-cooled and water-moderated experimental reactor used for testing boiling water reactor technology. The reactor was operated remotely from a trailer located approximately $800 \mathrm{~m}$ $(0.5 \mathrm{mi})$ southeast of the reactor, near the EBR-I area entrance. The BORAX-I reactor installation

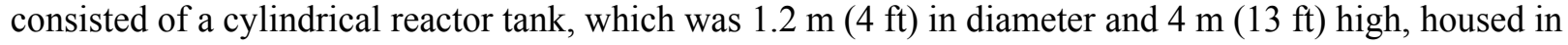
a steel shield tank $3 \mathrm{~m}(10 \mathrm{ft})$ in diameter, $6 \mathrm{~m}(20 \mathrm{ft})$ deep, and supported by a concrete slab. The bottom half of the shield tank was below ground level, while the top half was covered by a sand and gravel mound built up from the ground level. The shield tank was open on top. Adjacent to the shield tank was a pit with concrete walls that contained equipment for filling and emptying the reactor and shield tanks with water, and equipment for preheating the water in the reactor tank. The burial ground is contained within the foundation of the BORAX-I installation, the dimensions of which are $5.5 \times 9.8 \times 3.4 \mathrm{~m}$ $(18 \times 32 \times 11 \mathrm{ft})$.

On July 22, 1954, the final experiment with the BORAX-I reactor was performed at a time chosen for low wind conditions. Within a few seconds after the ejection of the control rod, it was apparent that the entire superstructure of the reactor had been displaced by the resulting steam explosion. The resulting explosion tore the reactor vessel completely apart and removed all but the dished bottom from the shield tank. The excursion contaminated approximately $7,800 \mathrm{~m}^{2}\left(84,000 \mathrm{ft}^{2}\right)$ of ground, in a strip approximately

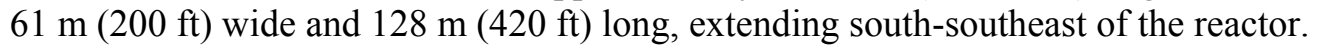

An investigation immediately following the excursion revealed that debris was scattered over the area to the south-southeast of the reactor. During 1954, attempts were made to reduce the radiation by physically removing pieces of radioactive material that had been scattered south of the reactor. However, their removal did not reduce radiation levels significantly. The contaminated area of approximately $7,800 \mathrm{~m}^{2}\left(84,000 \mathrm{ft}^{2}\right)$ was covered with gravel to a depth of $15 \mathrm{~cm}(6 \mathrm{in}$.). As a result, the dosage rates were reduced to less than $5 \mathrm{mrem} / \mathrm{hr}$ over the entire area, compared with rates of 500 to $800 \mathrm{mrem} / \mathrm{hr}$ measured prior to the gravel being laid.

BORAX-II was constructed in late 1954. Tests of new core combinations were performed using varying enrichments of uranium-235 in the metal fuel plates. The power level was approximately 6.4 MW(t), but, since it had no turbine generator, no electricity was produced. The energy produced was released in the form of steam. In 1955, a turbine-generator was added to BORAX-II and testing was performed to demonstrate that turbine contamination would not be a significant problem. This testing was continued with BORAX-III.

As a result of the BORAX-I and BORAX-II tests, a program was undertaken in March of 1955 to modify the BORAX reactor to produce electrical energy of the order of 2,000 kW, enough to provide the town of Arco, Idaho, with complete electrical service. At that point in time, no city in the world had been powered entirely by nuclear energy. This modified reactor became BORAX-III. The previous BORAX reactors were not designed to produce electricity, so a turbine-generator was added to the facility to convert the thermal energy into electricity. On July 17, 1955, electricity produced by BORAX-III supplied the town of Arco, Idaho, with its entire supply of electrical power. BORAX-III became the first nuclear power plant in the world to generate electricity for an entire city (AEC 1955). BORAX-III was used until 1956. 
The BORAX-IV reactor, which was the successor to BORAX-III, began operation in December of 1956. This reactor, with a design power of $20 \mathrm{MW}(\mathrm{t})$, was used principally to test high-thermal-capacity fuel elements made from ceramics of uranium and thorium. Like the previous BORAX reactors, BORAX-IV was a boiling water reactor. On the basis of the BORAX-IV experiments, it was predicted that a boiling reactor, fueled with ceramic fuel, can safely operate for long periods of time with many fuel cladding defects. BORAX-IV operated until June of 1958, after which it was replaced by BORAX-V.

In 1958, a proposal to construct an extremely flexible boiling water reactor was submitted (BORAX-V). The primary objective was testing various nuclear superheating concepts and advancing the art of boiling water reactor design. The greatest departure in design for BORAX-V from the previous BORAX reactors is found in the superheater. From 1962 to 1964, BORAX-V was used with an integral nuclear superheat system. The BORAX-V reactor, containing a core with a peripherally located superheater, was successfully operated from April through August of 1964. This marked the first prolonged operation of an integral boiling water-nuclear fuel superheating reactor in the United States. The BORAX-V project was terminated at the end of August 1964.

1.3.2.1 Environmental Setting-BORAX and EBR-I. Areas surrounding the BORAX and EBR-I support native communities. Sagebrush-steppe on lava communities are dominated by sagebrush (Artemisia tridentata), with large components of green rabbitbrush (Chrysothamnus viscidiflorus) and bluebunch wheatgrass (Pseudoroegneria spicata) and make up nearly $90 \%$ of the natural cover in the area (INEEL 2002). The relatively continuous stretches of sagebrush steppe around the BORAX and EBR-I make good habitat for many game species like sage grouse (Centrocercus urophasianus), mule deer (Odocoileus hemionus), and pronghorn (Antilocapra americana). No areas of critical habitat, as defined in 40 Code of Federal Regulations (CFR) 300, are known to exist at or near the BORAX and EBR-I.

\subsubsection{Contaminants of Potential Concern-BORAX and EBR-I. The BORAX and EBR-I} sites included a series of reactor experiments that in the past generated radioactive waste, hazardous waste, mixed waste, sanitary waste, and industrial waste. As shown in Table 1-2, COPCs include radionuclides (e.g., Cs-137) and metals (e.g., lead). Due to the potential of the contamination in the area from the criticality experiment, uranium isotopes may also be present. See Table 1-3 for the requested quantitation limits.

1.3.2.3 Probable Transport Pathways-BORAX and EBR-I. Metals and radionuclides can affect animals through skin contact, inhalation, and ingestion. Ecological receptors such as deer mice or cottontail rabbits are most likely to contact the contaminants during foraging and burrowing. Animals could ingest soil-absorbed contaminants during feeding, preening, and grooming. Plants and invertebrates could bioaccumulate contaminants, and, through the food web, other animals could be exposed indirectly by eating plants or invertebrates that have absorbed or adsorbed contaminants from soil. During high winds, animals could inhale and ingest particulates. Ingestion also could occur if animals consume plants or invertebrates that have contaminated dust on them.

1.3.2.4 Selection of Sampling Locations-BORAX and EBR-I. The areas outside the BORAX and EBR-I facility fence were gridded off into 100- $\times 100-\mathrm{m}(110-\times 110$-yd) plots. Then five plots were randomly selected for sampling, but selected plots were subsequently moved to ensure that areas of concern were addressed (Figure 1-4).

\subsubsection{Naval Reactors Facility (WAG 8)}

The Naval Reactors Facility (NRF), established in 1949, is a testing site for the Naval Nuclear Propulsion Program. Located in west-central INL, NRF consists of three naval nuclear reactor prototype plants, the Expended Core Facility, and miscellaneous support buildings. The Submarine Thermal Reactor Prototype (S1W) operated between 1951 and 1989, when it was permanently shut down. The 
Large Ship Reactor Prototype operated between 1958 and 1994, when it was permanently shut down. Operation of the Submarine Reactor Plant Prototype began in 1965 and was permanently shut down in 1995. In addition to a research and development mission, thousands of sailors trained on the prototypes for the nuclear navy. The Expended Core Facility has been used since 1958 for receiving, inspecting, and conducting tests on naval nuclear fuel. The Dry Storage Overpack Facility was completed in 2001 to store expended Naval nuclear fuel in a non-aqueous environment.

The NRF Industrial Waste Ditch is a 3.2-mile-long channel that has received nonradioactive wastewater from various operations at the NRF since 1953. Currently, water is rarely visible beyond 150 yards of the channel due to significantly reduced discharges after the prototype plants were shutdown.

1.3.3.1 Environmental Setting-Naval Reactors Facility. The NRF located is near the Big Lost River. The Big Lost River is one of three streams flowing on the INL that are essentially intermittent and drain the mountain areas to the north and west of INL. Most of this flow is diverted for irrigation in the summer months before it reaches the Site boundaries. Flow that reaches INL infiltrates the ground surface along the length of the stream beds in the spreading areas at the southern end of INL and, if the stream flow is sufficient, in the ponding areas (playas or sinks) in the northern portion of INL. During dry years, there is little or no surface water flow on the INL Site. The aspect is generally flat with the terrain gradually sloping toward the Big Lost River channel.

There are two types of surficial sedimentary deposits common at NRF. The surface "top soils" are loess deposits. Analysis of the loess shows that its primary constituent is the clay montmorillonite with secondary constituents of illite, quartz, feldspar, and carbonates (Chen-Northern 1991). Montmorillonite is a swelling clay and possesses a high cation exchange capacity. The thickness of the loess near NRF varies from several inches to over $10 \mathrm{ft}$ (EG\&G 1984; Envirodyne Engineers 1988). In some isolated locations near NRF, winnowing has caused fine-grain sand dune deposits to form. In most places near $\mathrm{NRF}$, the loess and sand deposits overlie alluvial deposits.

NRF is located at the western edge of an alluvial (meander) plain. This plain is several miles wide and consists of well rounded but poorly sorted sand and gravel interbedded with silt and clay. Most of the gravel clasts consist of a wide variety of rock types originating from the mountains located north and west of NRF, and include sedimentary, metamorphic, and igneous (plutonic) rocks. Some of the clasts are composed of basalt derived from the surrounding hills. Clay and fine silt interbeds are found sporadically throughout the alluvium but are commonly found at the basalt/alluvium interface. These clay interbeds usually possess lower permeability than the surrounding sand and gravel. Past geologic investigations have demonstrated that the formation of perched water is facilitated by infilling of fractures in the top of the basalt with clay.

Vegetation in the area predominantly consists of sagebrush and crested wheatgrass with lesser amounts of other shrubs, grasses, and forbs. The surrounding areas provide relatively continuous stretches of good sagebrush habitat both on and off lava. Wildlife species present in and around NRF include birds, mammals, and reptiles that are attracted to the habitat provided by facilities, sagebrush-steppe, rock outcroppings, deciduous trees and shrubs, grasslands, and water (e.g., drainage areas). Both aquatic and terrestrial species are potentially present. Sagebrush-steppe habitat supports a number of species including sage grouse, pronghorn, elk, and waterfowl. Grasslands provide habitat for species such as the western meadowlark and mule deer. Rock outcroppings support species such as bats, woodrats, and sensitive species such as the pygmy rabbit (Brachylagus idahoensis). Aside from vegetation, facilities within NRF also provide important habitat. Buildings, lawns, ornamental vegetation, and ponds are used by a number of species such as waterfowl, raptors, rabbits, and bats.

Six terrestrial avian species that are listed as T/E or sensitive species have the potential to occur near NRF. These include the ferruginous hawk (Buteo regalis), the peregrine falcon (Falco peregrinus), 
the northern goshawk (Accipiter gentilis), the loggerhead shrike (Lanius ludovicianus), the burrowing owl (Athene cunicularia), and the bald eagle (Haliaeetus leucocephalus). Four sensitive mammal species potentially exist in the vicinity, including the pygmy rabbit, Townsend's western big-eared bat (Plecotus townsendii), long-eared myotis (Myotis evotis), and small-footed myotis (Myotis subulatus). The sagebrush lizard (Sceloporus graciosus) is the only sensitive reptile species potentially present. No areas of critical habitat, as defined in 40 CFR 300, are known to exist in or around the NRF.

The NRF Industrial Waste Ditch is located outside the fenced area, northwest of the facility. Water within the ditch generally flows year-round and supports wetland species including bulrush (Scirpus acutus) and cattails (Typha latifolia). The ditch is a significant water source for plants and wildlife in the area. It was mapped as part of the Fish and Wildlife Service National Wetlands Inventory (Hampton et al. 1995). In the 1970s and 1980s, a number of studies were conducted citing waterfowl and other wildlife use of this area.

\subsubsection{Contaminants of Potential Concern-Naval Reactors Facility. The NRF site} includes a number of research and support facilities that contributed to the total volume of waste generated. These facilities in the past generated radioactive waste, hazardous waste, mixed waste, sanitary waste, and industrial waste. As shown in Table 1-2, COPCs include metals (e.g., lead). See Table 1-3 for the requested quantitation limits. Planned remedial actions at NRF under CERCLA have been completed. These actions included the placement of engineered covers for the containment of contaminants on inactive landfill areas and inactive leaching pond/beds and removal actions at radiologically contaminated sites.

Past discharges to the NRF Industrial Waste Ditch consisted primarily of run-off containing trace metals and hydrocarbons, cooling water containing dilute acid and corrosion-inhibiting heavy-metal compounds, industrial wastewater containing traces of oil, acidic and basic ion exchange regenerant solutions from water treatment, and laboratory reagents. A risk assessment completed for COPCs determined that the NRF Industrial Waste Ditch presented no unacceptable risks to human or ecological receptors. The NRF Industrial Waste Ditch therefore became a "No Action" site under CERCLA. Current discharges consist primarily of neutralized ion exchange regeneration solutions and storm water run-off.

1.3.3.3 Probable Transport Pathways-Naval Reactors Facility. Metals and radionuclides can affect animals through skin contact, inhalation, and ingestion. Ecological receptors such as deer mice or cottontail rabbits are most likely to contact the contaminants during foraging and burrowing. Animals could ingest soil-absorbed contaminants during feeding, preening, and grooming. Plants and invertebrates could bioaccumulate contaminants, and, through the food web, other animals could be exposed indirectly by eating plants or invertebrates that have absorbed or adsorbed contaminants from soil. During high winds, animals could inhale and ingest particulates. Ingestion also could occur if animals consume plants or invertebrates that have contaminated dust on them.

Contaminants at the ditch could affect animals through skin contact, inhalation, ingestion, and external exposure. Animals could ingest contaminants during drinking. Invertebrates in direct contact with contaminated water or sediments could bioaccumulate contaminants. Animals could then be exposed indirectly by eating plants or animals that have absorbed or adsorbed contaminants. During high winds, animals could inhale and ingest particulates.

1.3.3.4 Selection of Sampling Locations-Naval Reactors Facility. Locations at the NRF that have good habitat and possible contamination, but are disturbed little by roads or other facility activities, were gridded into $100-\times 100-\mathrm{m}(110-\times 110$-yd) plots. Then 10 plots were chosen for sampling. Plots 4, 7, and 10 will be adjusted as needed such that intrusions into the engineered covers are not required (Figure 1-5). 


\subsubsection{Terrestrial Reference Area}

The terrestrial reference area locations within the INL are represented by the circles on Figure 1-1. The reference area locations were selected by considering soil type, disturbance, and habitat type. These three types of information are critical when interpreting the population data. Sagebrush-steppe dominates the potentially impacted areas, so the reference area habitat type matches the potentially impacted area's habitat type to the greatest extent possible. The reference areas were selected from the proposed region where the three critical variables most closely match the potentially contaminated sites. Five sampling plots were randomly selected at each reference area location. The locations were surveyed using a global positioning system (GPS) unit and are shown in Figures 1-6 and 1-7.

\subsubsection{Aquatic Reference Area}

Chilly Slough, a marshy area located upstream from Mackay Reservoir, is the aquatic reference area. It is outside the known INL Site contamination plume and should have negligible impact from the INL (Figure 1-8). Five sampling locations in the same area that was sampled in 2006 will be selected based on the presence of water and/or aquatic plants. 


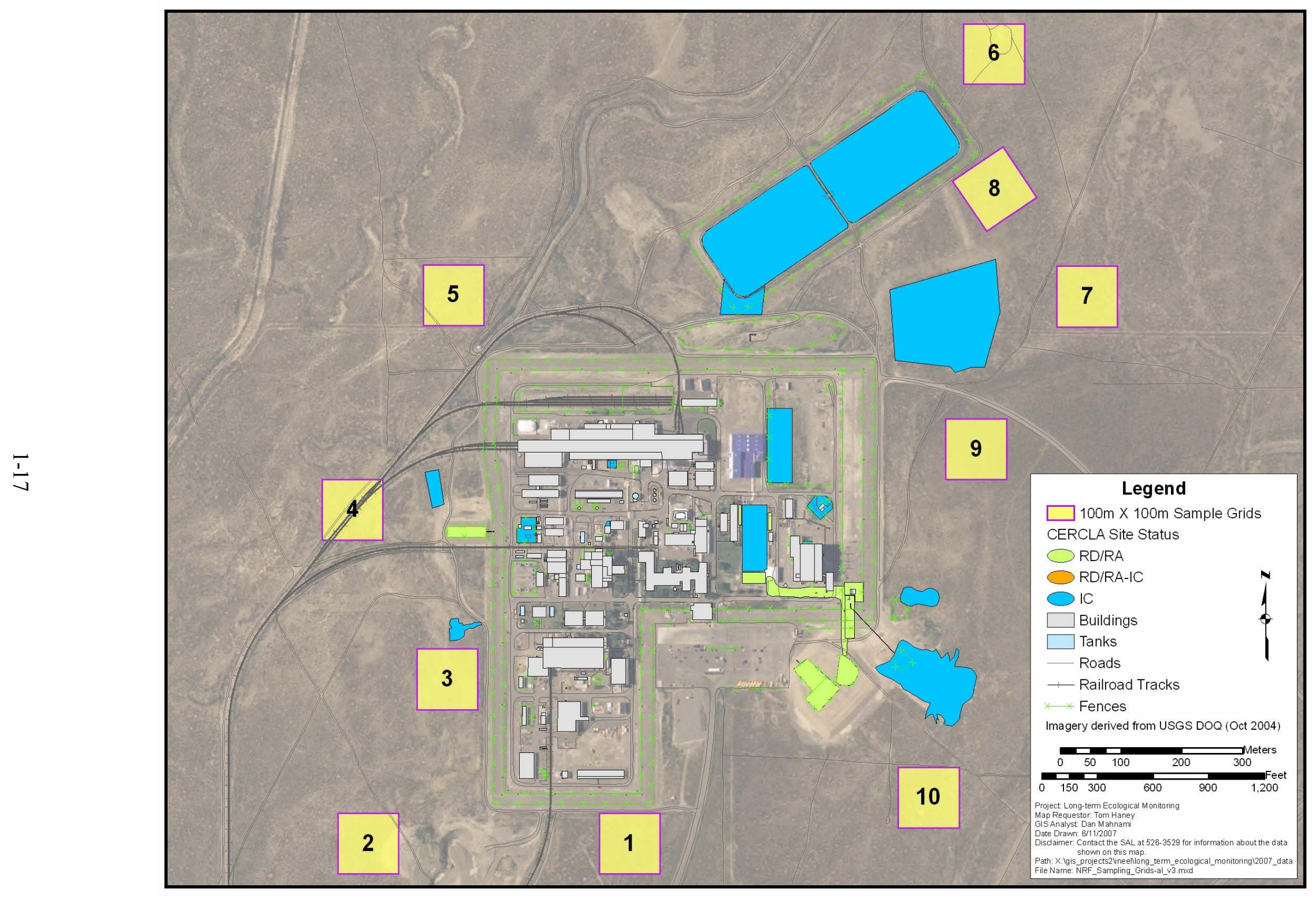

Figure 1-5. Map showing the location of the NRF sampling grids. 


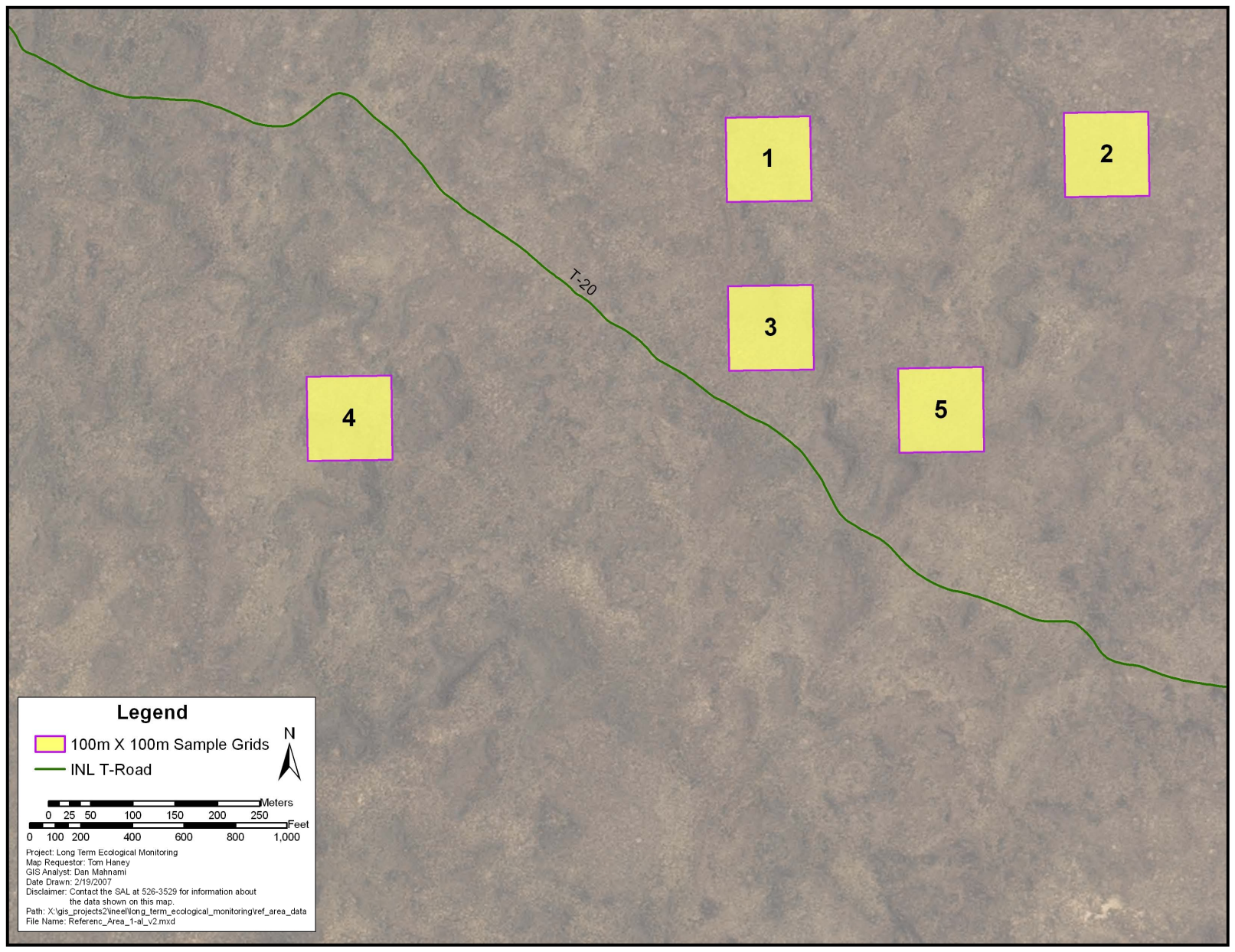

Figure 1-6. Map showing the location of Terrestrial Reference Area 1. 


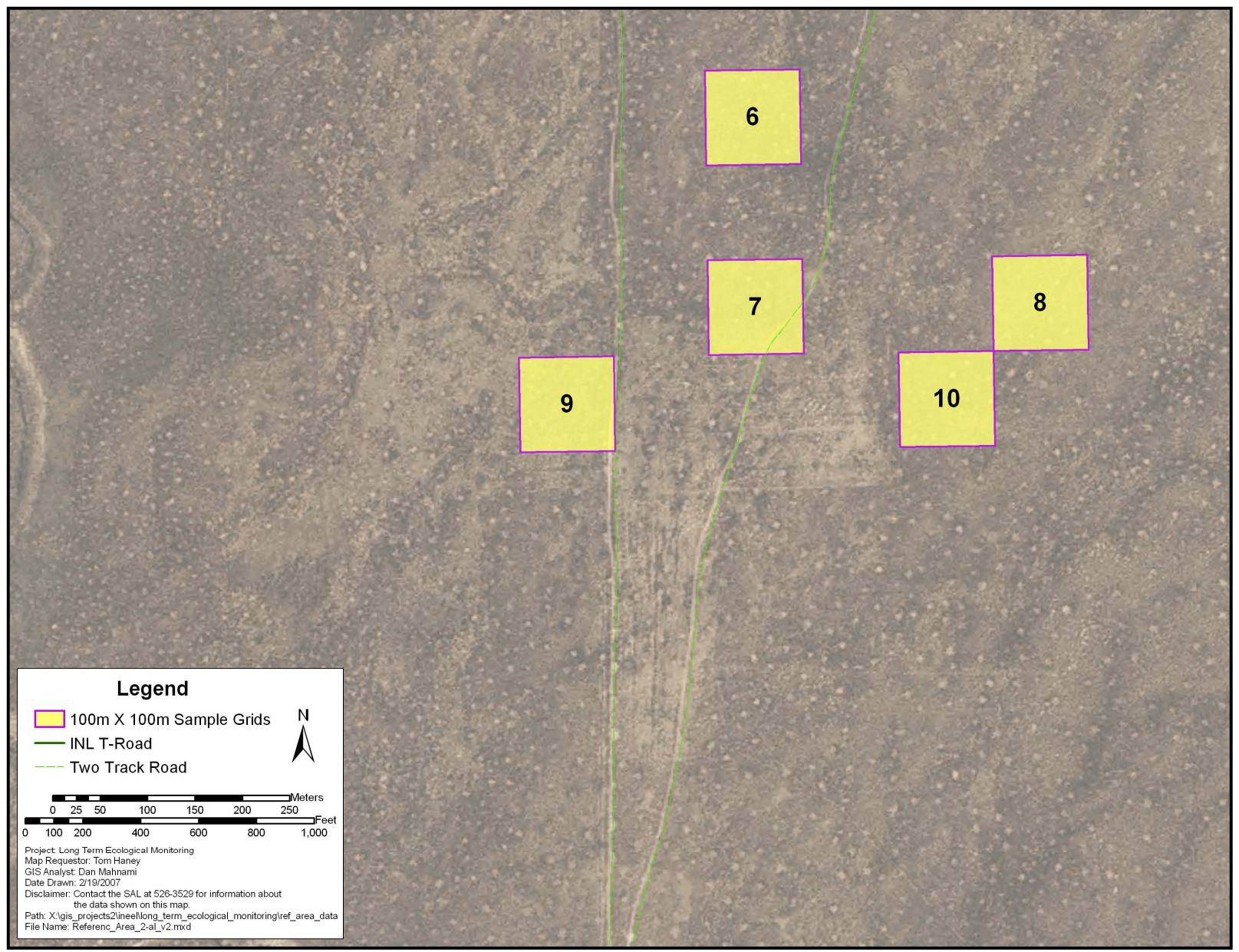

Figure 1-7. Map showing the location of Terrestrial Reference Area 2. 


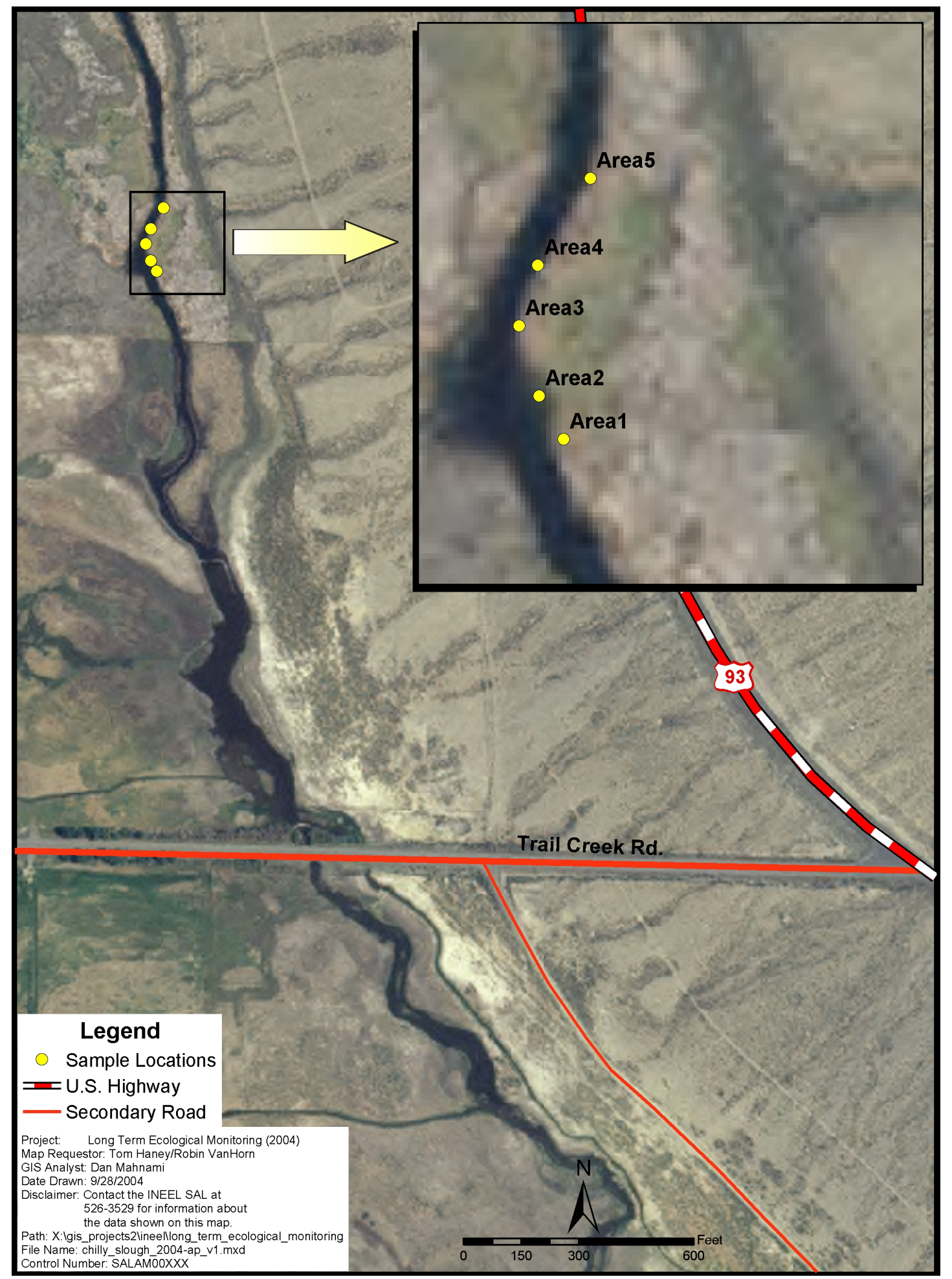

Figure 1-8. Map showing the location of Chilly Slough, the aquatic reference area. 


\section{PROJECT ORGANIZATION AND RESPONSIBILITIES}

Sections 2.1 through 2.10 describe the personnel associated with this FSP. Table 2-1 lists key personnel assignments and contact information. These responsibilities may change throughout the sampling effort. A logbook entry will be made to show the name of the individual performing the function. Most of the personnel descriptions are provided in the "Miscellaneous Sites Cleanup Project Health and Safety Plan" (PLN-2128). Descriptions of those personnel not included in that document are provided below.

Table 2-1. Proposed personnel and job assignments.

\begin{tabular}{lll}
\multicolumn{1}{c}{ Assignment } & \multicolumn{1}{c}{ Name } & \multicolumn{1}{c}{ Phone } \\
\hline Work project manager & Tom Haney & $208-526-9407$ \\
Technical lead & Robin VanHorn & $208-526-1650$ \\
Field team leaders & Tom Haney/Robin VanHorn & $208-526-9407 / 208-526-1650$ \\
Health and safety officer & Lawrence (Mic) McManamon & $208-526-3658$ \\
Samplers & TBD & TBD \\
Waste Generator Services & Blair Willis & $208-526-5217$ \\
Sample and Analysis & Lala Chambers & $208-526-4854$ \\
Management Program & & $208-526-7990$ \\
Environmental lead & Lee Tuott & $208-526-1073$ \\
Quality Assurance & Don Warner & TBD \\
Environmental Restoration & TBD & \\
Project operations manager & & \\
\hline TBD $=$ to be determined. & & \\
\hline
\end{tabular}

\subsection{Technical Lead}

The technical lead is responsible for field activities and for all personnel, including craft personnel, assigned to work at the project location. The technical lead is the interface between operations and project personnel and works to ensure that the sampling team achieves the project's objectives in a safe and efficient manner. The technical lead coordinates all document preparation, field and laboratory activities, data evaluation, risk assessment, dose assessment, and design activities.

\subsection{Waste Generator Services Waste Technical Specialist}

The INL Site Waste Generator Services (WGS) waste technical specialist ensures that waste disposal complies with approved INL Site waste management procedures. The WGS personnel have the responsibility to help solve waste management issues at the task site. In addition, WGS personnel prepare the appropriate documentation for waste disposal and make the proper notifications, as required. All waste is disposed of using approved INL Site procedures in accordance with Program Requirements Document (PRD) -5030, "Environmental Requirements for Facilities, Processes, Materials and Equipment." 


\subsection{Sample and Analysis Management Personnel}

The Sample and Analysis Management (SAM) personnel are responsible for helping to define the analyses that will meet project requirements, generating the sampling and analysis plan table and field guidance form, and generating and issuing sample labels. The SAM personnel determine the laboratory that will provide analytical services, based on established policies and contracts, and prepare the statement of work. The SAM personnel also track analytical progress and perform a cursory review of the final data packages. SAM personnel obtain data validation as directed by the project.

\subsection{Environmental Support}

The environmental personnel are assigned to the job site to provide resources and expertise to resolve environmental issues. Personnel assigned to provide this support must be qualified to recognize and evaluate environmental concerns according to his or her expertise and are given the authority to take or direct immediate actions to ensure compliance and protection. In addition, environmental personnel assess and ensure compliance with applicable ICP procedures and documentation, including this document. 


\section{DATA QUALITY OBJECTIVES}

The Environmental Protection Agency (EPA) -developed data quality objective (DQO) process (EPA 2000) helps ensure that the type, quantity, and quality of data used in decision-making are appropriate for the intended application. The DQOs presented in this FSP are consistent with, but are not identical to, those presented in the LTEM Plan (INEEL 2004). These DQOs correspond to the field sampling activities planned for 2007, whereas the LTEM Plan has a broader, long-term focus. The DQOs for 2007 are summarized in Table 3-1.

Table 3-1. Data quality objectives for 2007 long-term ecological monitoring.

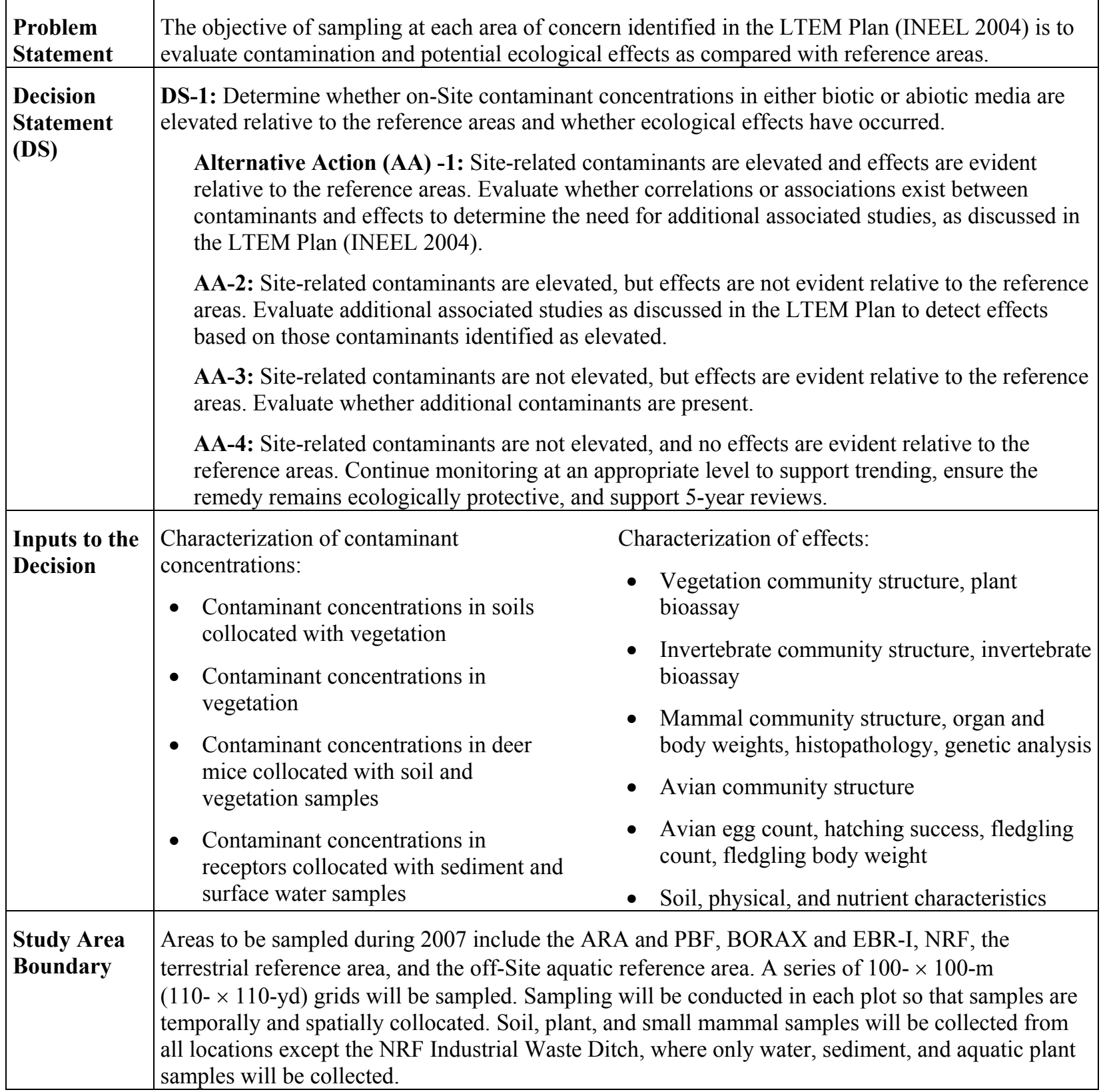


Table 3-1. (continued).

\begin{tabular}{|c|c|}
\hline $\begin{array}{l}\text { Decisi } \\
\text { Rules }\end{array}$ & $\begin{array}{l}\text { If analyte concentrations in any media exceed those at the reference areas ( } \mathrm{p}<0.05 \text { or other } \\
\text { appropriate background evaluation), then determine whether a correlation exists between } \\
\text { contaminants and effects and whether additional associated studies are needed as discussed in the } \\
\text { LTEM Plan (INEEL 2004). } \\
\text { If site-related contaminant concentrations are significantly elevated compared to the reference area } \\
\text { but no effects are apparent relative to the reference areas based on data evaluations, then evaluate } \\
\text { the need for additional associated studies, as discussed in the LTEM Plan, to detect effects based on } \\
\text { those contaminants identified as elevated. } \\
\text { If site-related contaminant concentrations are not significantly elevated compared to the reference } \\
\text { area, but effects are evident relative to the reference areas based on an evaluation of the data, then } \\
\text { identify additional sampling requirements to evaluate whether additional contaminants are present. } \\
\text { No further sampling will be performed if effects are determined to be related to physical } \\
\text { disturbance, such as soil compaction or removal of topsoil. } \\
\text { If site-related contaminant concentrations are not significantly elevated and no effects are evident } \\
\text { relative to the reference areas based on an evaluation of the data, then perform monitoring at an } \\
\text { appropriate level for trending, ensuring the remedy remains ecologically protective and supporting } \\
\text { 5-year reviews. }\end{array}$ \\
\hline $\begin{array}{l}\text { Specify } \\
\text { Tolerable } \\
\text { Limits on } \\
\text { Decision } \\
\text { Errors }\end{array}$ & $\begin{array}{l}\text { Analyte concentrations can range from below detection limits to well above reference area } \\
\text { concentrations. Because the study design is based on professional judgment and the sample size is } \\
\text { fixed at } 10 \text { random locations, pre-set limits on the decision error are not applicable. Statistics will } \\
\text { be applied to evaluate trends. Error analysis will be carried out when feasible. The data are being } \\
\text { collected for long-term needs that cannot be quantified at this point. The limits on decision errors } \\
\text { are used to determine sample size, which in this case was based on expert knowledge to maximize } \\
\text { resources. }\end{array}$ \\
\hline $\begin{array}{l}\text { Optimize the } \\
\text { Sampling } \\
\text { Design }\end{array}$ & $\begin{array}{l}\text { The sampling design focuses on areas near the facilities most likely to be impacted by } \\
\text { contamination. If elevated concentrations in various media are not found close to the facility, it is } \\
\text { unlikely they would be found farther away. }\end{array}$ \\
\hline \multicolumn{2}{|c|}{$\begin{array}{l}\text { ARA = Auxiliary Reactor Area } \\
\text { BORAX = Boiling Water Reactor Experiment } \\
\text { DS = decision statement } \\
\text { EBR-I = Experimental Breeder Reactor } \\
\text { LTEM = long-term ecological monitoring } \\
\text { NRF = Naval Reactors Facility } \\
\text { PBF = Power Burst Facility }\end{array}$} \\
\hline
\end{tabular}




\section{SAMPLE COLLECTION, ANALYSIS, AND DATA MANAGEMENT \\ 4.1 Sample Collection}

\subsubsection{Presampling Meeting}

Before sampling, project personnel will meet to ensure that sampling can be performed in a safe and compliant manner that will result in usable data. Project personnel also will ensure that all necessary equipment and documentation are present and all personnel understand the project scope, objectives, hazards, and hazard controls.

\subsubsection{Sampling and Analysis Requirements}

Tables 4-1 through 4-7 provide general summaries of the areas to be sampled, analytes, sample depths and types, and the number of samples for the major analyses. Appendix A includes the sampling and analysis plan tables and the field guidance forms that together include all sample descriptions, locations, analysis types, quantities, containers, holding times, and preservative requirements that apply to samples being collected under this FSP.

In 2007, soil disturbances ranking and soil descriptions will be provided for each plot sampled. Previously sampled plots will be revisited and also assigned a disturbance ranking and soil description. Plots sampled previous to 2004 are identified in the yearly FSPs (Haney and VanHorn 2003, 2006; Haney, VanHorn, and Fordham 2004; Haney et al. 2005).

Table 4-1. Composite biotic and collocated soil samples at BORAX and EBR-I for analytical assessment.

\begin{tabular}{|c|c|c|c|c|}
\hline Analytes & $\begin{array}{l}\text { Sample } \\
\text { Depth }\end{array}$ & $\begin{array}{l}\text { Sample } \\
\text { Media }\end{array}$ & Sample Type & $\begin{array}{c}\text { Number of } \\
\text { Samples }\end{array}$ \\
\hline \multirow{5}{*}{$\begin{array}{l}\text { Metals (target analyte } \\
\text { list [TAL]) } \\
\text { ( } \mathrm{Sb}, \mathrm{As}, \mathrm{Ba}, \mathrm{Be}, \mathrm{Cd} \text {, } \\
\mathrm{Cr}, \mathrm{Co}, \mathrm{Cu}, \mathrm{Hg}, \mathrm{Pb} \text {, } \\
\mathrm{Mn}, \mathrm{Ni}, \mathrm{Se}, \mathrm{Ag}, \mathrm{Sr} \\
\text { Tl, V, } \mathrm{Zn} \text { ) }\end{array}$} & $\begin{array}{l}0 \text { to } 5 \mathrm{~cm} \\
(0 \text { to } 2 \text { in.) }\end{array}$ & Soil & $\begin{array}{l}\text { Surface composite-five } \\
\text { subsamples/plot }\end{array}$ & 5 \\
\hline & $\begin{array}{l}5 \text { to } 61 \mathrm{~cm} \\
\text { ( } 2 \text { to } 24 \text { in.) }\end{array}$ & Soil & Subsurface composite—five cores/plot & 5 \\
\hline & $\mathrm{NA}^{\mathrm{a}}$ & Deer mice & Composite of five to 10 animals/plot & 5 \\
\hline & NA & Sagebrush & $\begin{array}{l}\text { Composite of greater than five } \\
\text { plants/plot }\end{array}$ & 5 \\
\hline & NA & $\begin{array}{c}\text { Crested } \\
\text { wheatgrass }\end{array}$ & $\begin{array}{l}\text { Composite of greater than five } \\
\text { plants/plot }\end{array}$ & 5 \\
\hline \multirow{5}{*}{$\begin{array}{l}\text { Radionuclides } \\
\text { (gamma spec., Sr-90, } \\
\text { uranium isotopes) }\end{array}$} & $\begin{array}{l}0 \text { to } 5 \mathrm{~cm} \\
\text { ( } 0 \text { to } 2 \text { in.) }\end{array}$ & Soil & $\begin{array}{l}\text { Surface composite-five } \\
\text { subsamples/plot }\end{array}$ & 5 \\
\hline & $\begin{array}{l}5 \text { to } 61 \mathrm{~cm} \\
\text { ( } 2 \text { to } 24 \text { in.) }\end{array}$ & Soil & Subsurface composite—-five cores/plot & 5 \\
\hline & NA & Deer mice & $\begin{array}{l}\text { Composite of five to } 10 \text { animals/plot } \\
\text { (use the deer mice collected for the } \\
\text { selected metals sampling) }\end{array}$ & See above \\
\hline & NA & Sagebrush & $\begin{array}{l}\text { Composite of greater than five } \\
\text { plants/plot }\end{array}$ & 5 \\
\hline & NA & $\begin{array}{c}\text { Crested } \\
\text { wheatgrass }^{\mathrm{b}}\end{array}$ & $\begin{array}{l}\text { Composite of greater than five } \\
\text { plants/plot }\end{array}$ & 5 \\
\hline
\end{tabular}


Table 4-2. Composite biotic and collocated soil samples at the ARA for analytical assessment.

\begin{tabular}{|c|c|c|c|c|}
\hline Analytes & $\begin{array}{l}\text { Sample } \\
\text { Depth }\end{array}$ & $\begin{array}{l}\text { Sample } \\
\text { Media }\end{array}$ & Sample Type & $\begin{array}{c}\text { Number of } \\
\text { Samples }\end{array}$ \\
\hline \multirow{5}{*}{$\begin{array}{l}\text { Metals (TAL) } \\
\text { (Sb, As, Ba, Be, Cd, } \\
\mathrm{Cr}, \mathrm{Co}, \mathrm{Cu}, \mathrm{Hg}, \mathrm{Pb}, \\
\mathrm{Mn}, \mathrm{Ni}, \mathrm{Se}, \mathrm{Ag}, \mathrm{Sr} \\
\mathrm{Tl}, \mathrm{V}, \mathrm{Zn} \text { ) }\end{array}$} & $\begin{array}{l}0 \text { to } 5 \mathrm{~cm} \\
(0 \text { to } 2 \text { in.) }\end{array}$ & Soil & $\begin{array}{l}\text { Surface composite-five } \\
\text { subsamples/plot }\end{array}$ & 5 \\
\hline & $\begin{array}{l}5 \text { to } 61 \mathrm{~cm} \\
\text { ( } 2 \text { to } 24 \mathrm{in} .)\end{array}$ & Soil & Subsurface composite-five cores/plot & 5 \\
\hline & $\mathrm{NA}^{\mathrm{a}}$ & Deer mice & Composite of five to 10 animals/plot & 5 \\
\hline & NA & Sagebrush & $\begin{array}{l}\text { Composite of greater than five } \\
\text { plants/plot }\end{array}$ & 5 \\
\hline & NA & $\begin{array}{c}\text { Crested } \\
\text { wheatgrass }\end{array}$ & $\begin{array}{l}\text { Composite of greater than five } \\
\text { plants/plot }\end{array}$ & 5 \\
\hline \multirow{5}{*}{$\begin{array}{l}\text { Radionuclides } \\
\text { (uranium isotopes, } \\
\text { gamma spec., Sr-90) }\end{array}$} & $\begin{array}{l}0 \text { to } 5 \mathrm{~cm} \\
\text { ( } 0 \text { to } 2 \text { in.) }\end{array}$ & Soil & $\begin{array}{l}\text { Surface composite-five } \\
\text { subsamples/plot/ for laboratory analysis }\end{array}$ & 5 \\
\hline & $\begin{array}{l}5 \text { to } 61 \mathrm{~cm} \\
\text { ( } 2 \text { to } 24 \mathrm{in} .)\end{array}$ & Soil & $\begin{array}{l}\text { Subsurface composite-five cores/plot/ } \\
\text { for laboratory analysis }\end{array}$ & 5 \\
\hline & NA & Deer mice & $\begin{array}{l}\text { Composite of five to } 10 \text { animals/plot } \\
\text { (use the deer mice collected for the } \\
\text { selected metals sampling) }\end{array}$ & See above \\
\hline & NA & Sagebrush & $\begin{array}{l}\text { Composite of greater than five } \\
\text { plants/plot }\end{array}$ & 5 \\
\hline & NA & $\begin{array}{c}\text { Crested } \\
\text { wheatgrass }\end{array}$ & $\begin{array}{l}\text { Composite of greater than five } \\
\text { plants/plot }\end{array}$ & 5 \\
\hline
\end{tabular}

Table 4-3. Composite biotic and collocated soil samples at the PBF for analytical assessment.

\begin{tabular}{|c|c|c|c|c|}
\hline Analytes & $\begin{array}{l}\text { Sample } \\
\text { Depth }\end{array}$ & $\begin{array}{l}\text { Sample } \\
\text { Media }\end{array}$ & Sample Type & $\begin{array}{c}\text { Number of } \\
\text { Samples }\end{array}$ \\
\hline \multirow{5}{*}{$\begin{array}{l}\text { Metals (TAL) } \\
\text { ( } \mathrm{Sb}, \mathrm{As}, \mathrm{Ba}, \mathrm{Be}, \mathrm{Cd} \text {, } \\
\mathrm{Cr}, \mathrm{Co}, \mathrm{Cu}, \mathrm{Hg}, \mathrm{Pb}, \\
\mathrm{Mn}, \mathrm{Ni}, \mathrm{Se}, \mathrm{Ag}, \mathrm{Sr} \\
\mathrm{Tl}, \mathrm{V}, \mathrm{Zn})\end{array}$} & $\begin{array}{l}0 \text { to } 5 \mathrm{~cm} \\
(0 \text { to } 2 \text { in.) }\end{array}$ & Soil & $\begin{array}{l}\text { Surface composite-five } \\
\text { subsamples/plot }\end{array}$ & 5 \\
\hline & $\begin{array}{l}5 \text { to } 61 \mathrm{~cm} \\
\text { ( } 2 \text { to } 24 \mathrm{in} .)\end{array}$ & Soil & Subsurface composite—five cores/plot & 5 \\
\hline & $\mathrm{NA}^{\mathrm{a}}$ & Deer mice & Composite of five to 10 animals/plot & 5 \\
\hline & NA & Sagebrush & $\begin{array}{l}\text { Composite of greater than five } \\
\text { plants/plot }\end{array}$ & 5 \\
\hline & NA & $\begin{array}{c}\text { Crested } \\
\text { wheatgrass }^{\mathrm{b}}\end{array}$ & $\begin{array}{l}\text { Composite of greater than five } \\
\text { plants/plot }\end{array}$ & 5 \\
\hline \multirow{2}{*}{$\begin{array}{l}\text { Radionuclides } \\
\text { (uranium isotopes, } \\
\text { (gamma spec., Sr-90) }\end{array}$} & $\begin{array}{l}0 \text { to } 5 \mathrm{~cm} \\
(0 \text { to } 2 \text { in.) }\end{array}$ & Soil & $\begin{array}{l}\text { Surface composite-five } \\
\text { subsamples/plot/ for laboratory analysis }\end{array}$ & 5 \\
\hline & $\begin{array}{l}5 \text { to } 61 \mathrm{~cm} \\
\text { ( } 2 \text { to } 24 \mathrm{in} .)\end{array}$ & Soil & $\begin{array}{l}\text { Subsurface composite-five cores/plot/ } \\
\text { for laboratory analysis }\end{array}$ & 5 \\
\hline
\end{tabular}


Table 4-3. (continued).

\begin{tabular}{lcclc}
\hline Analytes & $\begin{array}{c}\text { Sample } \\
\text { Depth }\end{array}$ & $\begin{array}{c}\text { Sample } \\
\text { Media }\end{array}$ & \multicolumn{1}{c}{ Sample Type } & $\begin{array}{c}\text { Number of } \\
\text { Samples }\end{array}$ \\
\hline NA & Deer mice & $\begin{array}{l}\text { Composite of five to 10 animals/plot } \\
\text { (use the deer mice collected for the } \\
\text { selected metals sampling) }\end{array}$ & See above \\
NA & SA & Sagebrush & $\begin{array}{l}\text { Composite of greater than five } \\
\text { plants/plot } \\
\text { Crested } \\
\text { wheatgrass }\end{array}$ & $\begin{array}{l}\text { Composite of greater than five } \\
\text { plants/plot }\end{array}$ \\
\hline $\begin{array}{l}\text { a. NA = not applicable. } \\
\text { b. Or other grass. }\end{array}$ & & & 5 \\
\hline
\end{tabular}

Table 4-4. Composite biotic and collocated soil samples at the NRF for analytical assessment.

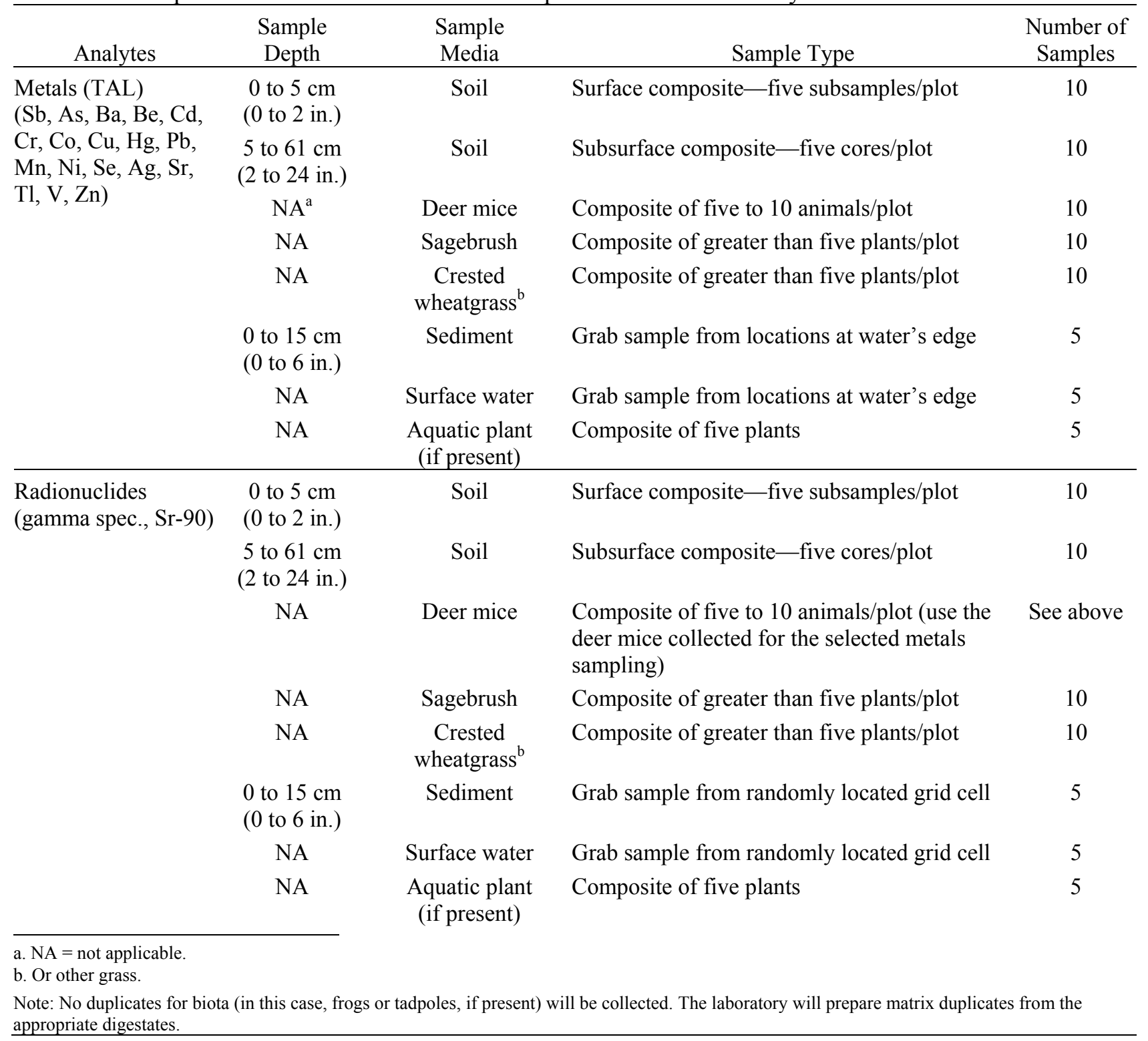


Table 4-5. Biotic samples for effects analysis.

\begin{tabular}{|c|c|c|c|c|c|}
\hline Assessment & $\begin{array}{l}\text { Sample } \\
\text { Depth }\end{array}$ & $\begin{array}{l}\text { Sample } \\
\text { Media }\end{array}$ & Sample Type & Location & $\begin{array}{c}\text { Total } \\
\text { Number } \\
\text { of Samples }\end{array}$ \\
\hline $\begin{array}{l}\text { Kidney and liver to body } \\
\text { weight ratio }\end{array}$ & $\mathrm{NA}^{\mathrm{a}}$ & Deer mice & $\begin{array}{l}\text { Five animals/plot (use deer } \\
\text { mice collected for the } \\
\text { analytical sampling) }\end{array}$ & $\begin{array}{l}\text { 50-NRF } \\
\text { 25-ARA } \\
\text { 25-BORAX/EBR-I }\end{array}$ & 100 \\
\hline Liver/kidney histopathology & NA & Deer mice & $\begin{array}{l}\text { Five animals/plot (use deer } \\
\text { mice collected for the } \\
\text { analytical sampling) }\end{array}$ & $\begin{array}{l}\text { 50-NRF } \\
\text { 25-ARA } \\
\text { 25-BORAX/EBR-I }\end{array}$ & 100 \\
\hline $\begin{array}{l}\text { Earthworm/seedling toxicity } \\
\text { testing }\end{array}$ & $\begin{array}{l}0 \text { to } 30 \mathrm{~cm} \\
(0 \text { to } 1 \mathrm{ft})\end{array}$ & Soil & $\begin{array}{l}\text { Composite from five } \\
\text { subplots at each plot }\end{array}$ & $\begin{array}{l}\text { 10-NRF } \\
\text { 5-ARA } \\
\text { 5-BORAX/EBR-I } \\
\text { 5-PBF }\end{array}$ & 25 \\
\hline Avian population & NA & Birds & $\begin{array}{l}\text { Point count locations } \\
\text { sampled }\end{array}$ & $\begin{array}{l}\text { 5-BORAX/EBR-I } \\
\text { 10-NRF } \\
\text { 10-Reference area }\end{array}$ & 25 \\
\hline Reptile population & NA & Reptiles & Observation & & $\begin{array}{c}\text { To be } \\
\text { determined }\end{array}$ \\
\hline Plant population & NA & Plant & $\begin{array}{l}50 \text { Daubenmire subplots } \\
\text { per plot }\end{array}$ & $\begin{array}{l}\text { 500-NRF } \\
\text { 250-ARA } \\
\text { 250-BORAX/EBR-I }\end{array}$ & 1,000 \\
\hline Animal population & NA & $\begin{array}{c}\text { Small } \\
\text { mammals }\end{array}$ & $\begin{array}{l}100 \text { traps per plot/for six } \\
\text { trapping nights ( } 2 \text { weeks })\end{array}$ & & NA \\
\hline
\end{tabular}

Table 4-6. Biotic samples at the Terrestrial Reference Area for effects analysis.

\begin{tabular}{|c|c|c|c|c|}
\hline Assessment & $\begin{array}{l}\text { Sample } \\
\text { Depth }\end{array}$ & $\begin{array}{l}\text { Sample } \\
\text { Media }\end{array}$ & Sample Type & $\begin{array}{c}\text { Number of } \\
\text { Samples }\end{array}$ \\
\hline $\begin{array}{l}\text { Kidney and liver to body } \\
\text { weight ratio }\end{array}$ & $\mathrm{NA}^{\mathrm{a}}$ & Deer mice & Five animals/plot & 50 \\
\hline $\begin{array}{l}\text { Liver/kidney } \\
\text { histopathology }\end{array}$ & NA & Deer mice & Five animals/plot & 50 \\
\hline $\begin{array}{l}\text { Earthworm/seedling } \\
\text { toxicity testing }\end{array}$ & $\begin{array}{l}0 \text { to } 30 \mathrm{~cm} \\
(0 \text { to } 1 \mathrm{ft})\end{array}$ & Soil & Composite from five subplots at each plot & NA \\
\hline Avian population & NA & Birds & 10-point count locations sampled three times & 30 \\
\hline Reptile population & NA & Reptiles & Observation & $\begin{array}{c}\text { To be } \\
\text { determined }\end{array}$ \\
\hline Plant population & NA & Plant & 50 Daubenmire subplots per plot & 500 \\
\hline Animal population & NA & $\begin{array}{c}\text { Small } \\
\text { mammals }\end{array}$ & $\begin{array}{l}100 \text { traps per plot/for six trapping nights } \\
(2 \text { weeks) }\end{array}$ & NA \\
\hline
\end{tabular}


Table 4-7. Biased composite biotic and collocated samples at the Aquatic Reference Area for analytical assessment.

\begin{tabular}{lcclc}
\hline \multicolumn{1}{c}{ Analytes } & $\begin{array}{c}\text { Sample } \\
\text { Depth }\end{array}$ & Sample Media & \multicolumn{1}{c}{ Sample Type } & $\begin{array}{c}\text { Number of } \\
\text { Samples }\end{array}$ \\
\hline $\begin{array}{l}\text { Metals (TAL) } \\
\text { (Sb, As, Ba, Cd, Cr, Co, }\end{array}$ & $\begin{array}{c}0 \text { to } 15 \mathrm{~cm} \\
\text { (0 to } 6 \text { in.) }\end{array}$ & Sediment & Grab sample from randomly located grid cell & 5 \\
$\begin{array}{l}\mathrm{Cu}, \mathrm{Hg}, \mathrm{Pb}, \mathrm{Mn}, \mathrm{Ni}, \mathrm{Se}, \\
\mathrm{Ag}, \mathrm{Sr}, \mathrm{Tl}, \mathrm{V}, \mathrm{Zn})\end{array}$ & $\mathrm{NA}^{\mathrm{a}}$ & Surface water & Grab sample from randomly located grid cell & 5 \\
\hline $\begin{array}{l}\text { Radionuclides } \\
\text { (gamma spec., Sr-90) }\end{array}$ & $\begin{array}{l}\text { Aquatic plant } \\
\text { (0 to } 6 \text { in.) }\end{array}$ & Composite of five plants & 5 \\
& NA & Surface water & Grab sample from randomly located grid cell & 5 \\
& NA & Aquatic plant & Composite of five plants & 5 \\
\hline
\end{tabular}

a. NA $=$ not applicable.

Note: No duplicates for biota will be collected. The laboratory will prepare matrix duplicates from the appropriate digestates.

The SAM Program is responsible for obtaining laboratory services for the required analyses in accordance with MCP-9439, "Environmental Sampling Activities at the INL.” The SAM Program will prepare two statements of work (SOWs) for laboratory services: (1) "Radiological Analyses of Samples Collected for the Long-Term Ecological Monitoring for 2007 at the INL" and (2) "Organic, Inorganic, and Miscellaneous Classical Analyses of Samples Collected for the Long-Term Ecological Monitoring for 2007 at the INL." These SOWs will include the analytical methods and the project-required detection limits for each analysis type listed in the sampling and analysis plan tables and field guidance forms (Appendix A). Detection limits for each analysis type are included in Table 1-3.

Samplers coordinate with SAM and the analytical laboratory to ensure that the samples arrive at the laboratory to meet holding times. Holding times for biota samples are not established; however, approval of holding times of 6 months to 1 year is likely based upon other ecological studies (Marsh, Fordham, and Loucks 1998). Biotic samples will be preserved by freezing.

When required, quality control samples will be collected. If, for some reason, a sample is lost, containers are broken, or the sample is in some way unusable, the sample will be retaken. The sampling field team leader (FTL) will ensure that any changes to this document regarding sampling frequency, location, and/or analyses are documented in the sample logbook. The project manager is responsible for ensuring that a Document Revision Form (DRF) (a Web application accessed through the Electronic Document Management System [EDMS]) is created and executed for any changes to this document.

A sampling logbook containing a written record for all field data gathered, field observations, field equipment calibrations, samples collected for analysis, and sample custody will be prepared. Field logbooks are legal documents that are maintained to ensure that field activities are documented properly as they relate to site safety meetings and site work being conducted in accordance with the health and safety procedures. The bound field logbooks contain consecutively numbered pages. All entries in field logbooks are made using permanent ink pens or markers. The person making corrections to an entry should draw a single line through the entry and then initial and date the correction. Data sheets will be used to collect data about plants and small mammals. The FTL will note the use of data sheets in the appropriate logbook. 


\subsubsection{Sample Documentation and Management}

The FTL controls and maintains all field documents and records and submits required documents to the Administrative Record and Document Control office at the project's end. The appropriate information pertaining to each sample is recorded in accordance with MCP-1194, "Logbook Practices for ICP CERCLA and Removal Action Projects"; MCP-1192, "Chain-of-Custody and Sample Labeling for ICP CERCLA and Removal Action Sampling Activities"; and the Quality Assurance Project Plan for Waste Area Groups 1, 2, 3, 4, 5, 6, 7, 10, and Removal Actions (DOE-ID 2006). The person designated to complete the sample or FTL logbook records items (such as presampling safety meeting notes, weather, and general project notes) in the logbook as appropriate. Proper handling, management, and disposal of samples under the control of CH2M-WG Idaho, LLC, or its subcontractors are essential. All samples are dispositioned in accordance with the appropriate procedures.

If it becomes necessary to revise project documents, a DRF will be executed in accordance with MCP-135, "Document Management." The revisions can include additional analyses that might be necessary to meet appropriate Waste Acceptance Criteria.

\subsubsection{Sampling Equipment, Calibration, and Setup}

Table 4-8 includes a list of equipment and supplies required for this project. This list is as extensive as possible and includes equipment for both the analytical and effects data collection; however, the list is not exhaustive and should only be used as a guide.

Table 4-8. Equipment and supplies list.

\begin{tabular}{|c|c|c|c|c|c|c|}
\hline & \multirow{2}{*}{$\begin{array}{c}\text { Plot } \\
\text { Preparation }\end{array}$} & \multirow{2}{*}{$\begin{array}{l}\text { Proximal Soil } \\
\text { Sampling }\end{array}$} & \multicolumn{2}{|c|}{ Mammal Sampling } & \multicolumn{2}{|c|}{ Vegetation Sampling } \\
\hline & & & Effects & Analytical & Effects & Analytical \\
\hline $\begin{array}{l}\text { Flexible tape, } 50 \mathrm{~m}(164 \mathrm{ft}) \text { or } \\
\text { longer }\end{array}$ & $\mathrm{X}$ & $\mathrm{X}$ & - & $\mathrm{X}$ & - & $\mathrm{X}$ \\
\hline Rulers & $\mathrm{X}$ & $\mathrm{X}$ & - & - & - & $\mathrm{X}$ \\
\hline Survey stakes & $\mathrm{X}$ & - & - & $\mathrm{X}$ & - & $\mathrm{X}$ \\
\hline $\begin{array}{l}\text { Field forms, logbooks, and } \\
\text { clipboards }\end{array}$ & $\mathrm{X}$ & $\mathrm{X}$ & - & $\mathrm{X}$ & - & $\mathrm{X}$ \\
\hline Flagging tape (various colors) & $\mathrm{X}$ & $\mathrm{X}$ & - & $\mathrm{X}$ & - & $\mathrm{X}$ \\
\hline Wildlife identification information & - & - & - & $\mathrm{X}$ & - & - \\
\hline $\begin{array}{l}\text { Small (mouse-sized) and medium } \\
\text { (rabbit-sized) live traps }\end{array}$ & - & - & - & $\mathrm{X}$ & - & - \\
\hline $\begin{array}{l}\text { Absorbent material (e.g., paper } \\
\text { towels and cloth rags) }\end{array}$ & - & $\mathrm{X}$ & - & $\mathrm{X}$ & - & $\mathrm{X}$ \\
\hline $\begin{array}{l}\text { Permanent markers, sample labels, } \\
\text { and bar codes }\end{array}$ & $\mathrm{X}$ & $\mathrm{X}$ & - & $\mathrm{X}$ & - & $\mathrm{X}$ \\
\hline Latex/nitrile gloves & - & $\mathrm{X}$ & - & $\mathrm{X}$ & - & $\mathrm{X}$ \\
\hline $\begin{array}{l}\text { EPA-approved sampling containers } \\
\text { as specified by the analytical } \\
\text { method (see QAPjP } \\
\text { [DOE-ID 2006]) }\end{array}$ & - & $\mathrm{X}$ & - & $X$ & - & $X$ \\
\hline Logbooks & - & $\mathrm{X}$ & $\mathrm{X}$ & $\mathrm{X}$ & $X$ & $\mathrm{X}$ \\
\hline
\end{tabular}


Table 4-8. (continued).

\begin{tabular}{|c|c|c|c|c|c|c|}
\hline & \multirow{2}{*}{$\begin{array}{c}\text { Plot } \\
\text { Preparation }\end{array}$} & \multirow{2}{*}{$\begin{array}{l}\text { Proximal Soil } \\
\text { Sampling }\end{array}$} & \multicolumn{2}{|c|}{ Mammal Sampling } & \multicolumn{2}{|c|}{ Vegetation Sampling } \\
\hline & & & Effects & Analytical & Effects & Analytical \\
\hline $\begin{array}{l}\text { Sealable plastic bags (various } \\
\text { sizes) }\end{array}$ & - & $\mathrm{X}$ & - & $\mathrm{X}$ & - & $\mathrm{X}$ \\
\hline Strapping tape and duct tape & - & $\mathrm{X}$ & - & $\mathrm{X}$ & - & $\mathrm{X}$ \\
\hline Data sheets & - & - & $\mathrm{X}$ & - & $\mathrm{X}$ & - \\
\hline $\begin{array}{l}\text { Distilled, deionized water } \\
\text { (including decontamination water) }\end{array}$ & - & $\mathrm{X}$ & - & $\mathrm{X}$ & - & $\mathrm{X}$ \\
\hline $\begin{array}{l}\text { Sample preservatives as specified } \\
\text { by analytical method (see FSP and } \\
\text { QAPjP) }\end{array}$ & - & $\mathrm{X}$ & - & - & - & - \\
\hline $\begin{array}{l}\text { Plastic tubs for rinsing sampling } \\
\text { equipment }\end{array}$ & - & $\mathrm{X}$ & - & $\mathrm{X}$ & - & $\mathrm{X}$ \\
\hline Tweezers, tongs, and forceps & - & - & - & $\mathrm{X}$ & - & $\mathrm{X}$ \\
\hline PPE, as specified in the JSA & $\mathrm{X}$ & $\mathrm{X}$ & - & $\mathrm{X}$ & - & $\mathrm{X}$ \\
\hline Aluminum foil or plastic wrap & - & $\mathrm{X}$ & - & - & $\mathrm{X}$ & - \\
\hline $\begin{array}{l}\text { Plastic bubble wrap, starch packing } \\
\text { beads, or foam sheeting for sample } \\
\text { shipment (no diatomaceous earth) }\end{array}$ & - & $\mathrm{X}$ & - & $\mathrm{X}$ & - & $\mathrm{X}$ \\
\hline $\begin{array}{l}\text { Laboratory scales: } 2 \text {-kg capacity } \\
\text { with } 0.1 \text {-g resolution; } 200-\mathrm{g} \\
\text { capacity with } 0.01 \text {-g resolution }\end{array}$ & - & - & $\mathrm{X}$ & $\mathrm{X}$ & - & $\mathrm{X}$ \\
\hline GPS unit & $\mathrm{X}$ & - & - & - & - & - \\
\hline $\begin{array}{l}\text { Bleach for decontaminating traps } \\
\text { and sampling tools }\end{array}$ & - & - & - & $\mathrm{X}$ & - & - \\
\hline $\begin{array}{l}\text { Pesola scales for weighing animals } \\
\text { (various sizes) }\end{array}$ & - & - & - & $\mathrm{X}$ & - & - \\
\hline Stainless-steel pans & - & $\mathrm{X}$ & - & $\mathrm{X}$ & - & $\mathrm{X}$ \\
\hline Ear tags & - & - & $\mathrm{X}$ & - & - & - \\
\hline Ear tagger & - & - & $\mathrm{X}$ & - & - & - \\
\hline Disinfectant wipes & - & - & $X$ & $\mathrm{X}$ & - & - \\
\hline Hand lens & - & $X$ & $X$ & - & $\mathrm{X}$ & - \\
\hline Dissecting kit & - & - & $\mathrm{X}$ & - & - & - \\
\hline $\begin{array}{l}\text { Stainless-steel scoops for soil } \\
\text { sampling }\end{array}$ & - & $\mathrm{X}$ & - & - & - & - \\
\hline Stainless-steel auger & - & $\mathrm{X}$ & - & - & - & - \\
\hline $\begin{array}{l}\text { Plastic containers (e.g., carboys) } \\
\text { for containing used rinse water }\end{array}$ & - & $\mathrm{X}$ & - & $\mathrm{X}$ & - & $\mathrm{X}$ \\
\hline Leather gloves (various sizes) & $\mathrm{X}$ & $\mathrm{X}$ & - & $\mathrm{X}$ & - & $\mathrm{X}$ \\
\hline Plant press & - & - & - & - & - & $\mathrm{X}$ \\
\hline Large and small coolers & - & $\mathrm{X}$ & - & $\mathrm{X}$ & - & $\mathrm{X}$ \\
\hline Reusable ice packs & - & $\mathrm{X}$ & - & $\mathrm{X}$ & - & $\mathrm{X}$ \\
\hline
\end{tabular}


Table 4-8. (continued).

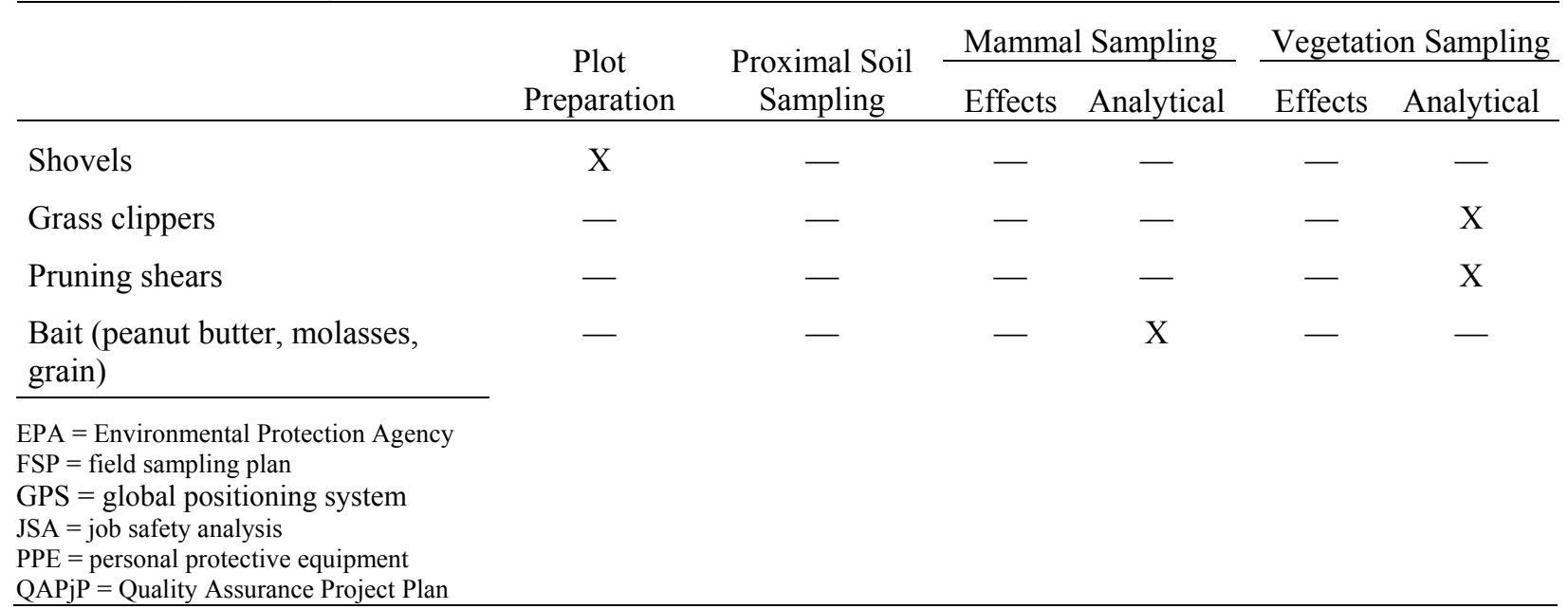

The FTL works closely with sampling personnel to ensure that sampling equipment is operating as recommended by the manufacturer and according to design specifications. Presampling inspections of equipment are conducted to ensure that the equipment is functioning properly. Corrective actions for repair or maintenance of any sampling equipment will be immediate and confirmed by the FTL or project manager before proceeding with sampling.

Radiological Control personnel are responsible for calibrating radiological monitoring equipment and placing and handling the telemetry dosimeters. Industrial Hygiene personnel are responsible for measuring and evaluating chemical hazards. All calibrations will be documented in the calibration logbooks.

\subsubsection{Sample Designation and Labeling}

Each sample bottle contains a label identifying the field sample number, the analyses requested, the sample date and time, and the sampler. Labels are secured on the sample using clear plastic tape.

Uniqueness is required for maintaining consistency and preventing the same identification code from being assigned to more than one sample. A systematic character code may be used to identify all samples uniquely.

\subsubsection{Chain of Custody}

Chain-of-custody (COC) procedures begin immediately after collecting the first sample. At the time of sample collection, the sampling team initiates a COC form for each sample. All samples remain in the custody of a sampling team member until custody is transferred to the analytical laboratory sample custodian. Upon receipt at the laboratory, the sample custodian reviews the sample labels and the COC form to ensure completeness and accuracy. If discrepancies are noted during this review, immediate corrective action is sought with the sampling team member(s) relinquishing custody as identified on the COC. Pending successful corrective action, the laboratory sample custodian signs and dates the COC form, signifying acceptance of delivery and custody of the samples.

\subsubsection{Sample Collection Procedures}

Samples will be collected using the procedures in Appendix B of this document; TPR-145, "Biotic and Proximal Soil Sampling"; and other relevant sampling procedures and guides, e.g., Guide (GDE) -279, "Surface Water Sampling for the Idaho Completion Project." 


\subsubsection{Equipment Decontamination Procedures}

Decontamination of most sampling equipment will be accomplished using guidance in GDE-282, "Decontaminating Ecological Sampling Equipment for the Idaho Completion Project."

\subsubsection{Sample Transport}

Field team members will prepare the samples for transport in accordance with MCP-1193, "Handling and Shipping Samples for ICP CERCLA and Removal Action Sampling Activities," by securing the labels using clear tape, placing parafilm or stretch tape on the bottles to secure the lids, and placing the bottles in sealed bags. The field team member will wrap the samples in cushioning material and place them in the sample cooler. If necessary, the field team member will place Blue Ice ${ }^{\mathrm{TM}}$ (or equivalent) ${ }^{\mathrm{a}}$ in the cooler to maintain the required temperature. The field team member will place the completed and signed COC form in the cooler, tape the cooler shut, and place the custody seals on the cooler to prevent tampering.

The field team member will complete the applicable shipping papers (ICP Form Series 460 [Packaging \& Transportation General] or 461 [Hazardous Materials P\&T], as applicable), secure address labels to the cooler, and deliver the coolers to the shipping authority for transport.

\subsubsection{Waste Management}

The analytical laboratory will dispose of samples submitted to it for analyses or will return them to the requestor as stated in the applicable SOWs. Samples returned from the laboratory will be accepted only if the original label is intact and legible. Any return of samples must be in accordance with 40 CFR 300.440(a)(5). If the samples are returned, the project manager is responsible for properly disposing of the sample with the assistance of WGS personnel. Disposal must be preapproved and documented by WGS personnel.

4.1.10.1 Solid Waste Management. Solid waste generated will include PPE trash and miscellaneous waste such as wipes and packaging. Waste that does not come into direct contact with the sampled media or sampling equipment can be disposed of as nonconditional, nonradioactive waste at the ARA and SL-1 landfill complex unless beta/gamma radiation or contamination above INL Site release criteria is detected.

All PPE and other waste material directly used in sampling, decontamination, etc., will be bagged and placed in containers recommended by WGS.

Waste generated during the characterization project includes samples, sampling equipment, and PPE. These articles are handled, characterized, and disposed of in accordance with the Idaho National Engineering and Environmental Laboratory Waste Acceptance Criteria (DOE-ID 2005). Personnel from WGS coordinate waste disposal activities in accordance with INL Site procedures. Waste will be bagged, placed in containers, labeled, and stored in an approved storage area pending disposition. The project manager, with assistance from WGS, will prepare waste determination and disposition forms for determining the disposition routes for all waste generated during sampling and analysis.

a. References herein to any specific commercial product, process, or service by trade name, trademark, manufacturer, or otherwise, does not necessarily constitute or imply its endorsement, recommendation, or favoring by the U.S. Government, any agency thereof, or any company affiliated with the Idaho National Laboratory. 
In the unlikely event that nonhazardous radioactive waste is generated, it will be disposed of at the Idaho CERCLA Disposal Facility (ICDF). WGS will approve and prepare individual waste streams destined for disposal at the ICDF in accordance with the ICDF Complex Waste Acceptance Criteria (DOE-ID 2007).

4.1.10.2 Soil-Specific Waste Management. Off-Site laboratories will dispose of both altered and unaltered samples as contractually required. However, on-Site laboratory gamma screening of samples may be completed, and these unaltered samples will be restored to the collection site. In the event that samples must be returned from the off-Site laboratory, only unused and unaltered samples in the original containers will be accepted. Although no samples are expected to be returned from the off-Site laboratory and all screening samples are expected to be eligible for return to the collection site, disposition of samples that cannot be restored to a collection site is coordinated with the appropriate waste generator interface. Such coordination will help to ensure compliance with applicable waste characterization, treatment, and disposal regulations.

Decontamination solutions used in small quantities might include deionized water, detergent, bleach/water, and (in the laboratory hood) isopropanol. It is anticipated that no decontamination fluids requiring containment will be generated during sampling. The use of spray bottles to apply the fluids will minimize the amount of decontamination fluids produced. Only clean water and biodegradable soap are used in the field for decontamination. Excess water will be allowed to drain onto the ground in the staging area used during sampling.

4.1.10.3 Waste Minimization. Waste reduction philosophies and techniques will be emphasized, and personnel will be encouraged to attempt to improve methods continuously. Personnel must not use, consume, spend, or expend equipment or materials carelessly. Practices to be instituted to support waste minimization include, but are not limited to, the following:

- $\quad$ Restrict material (especially hazardous material) entering control zones to what is needed to do the work

- $\quad$ Substitute recyclable or burnable items for disposable items

- $\quad$ Reuse items when practical

- $\quad$ Segregate contaminated from uncontaminated waste

- $\quad$ Segregate reusable items such as PPE and tools.

\subsection{Sample Analysis}

Laboratories on the ICP Qualified Suppliers List will be used to analyze the samples in accordance with project requirements, including ER-SOW-394, "Sample and Analysis Management Statement of Work for Analytical Services.”

Project-specific, request-for-analyses forms, or SOW(s), identify additional requirements for laboratory analysis. Sections 4.2.1 through 4.2.3 identify analysis requirements for the characterization project.

\subsubsection{Analytical Methods}

To ensure that data of acceptable quality are obtained from the characterization project, standard EPA laboratory methods or technically appropriate methods for analytical determinations will be used to obtain sample data. The SAM Program is responsible for obtaining laboratory analytical services for the required analyses in accordance with MCP-9439, "Environmental Sampling Activities at the INL." The 
SAM Program will prepare two SOWs for laboratory services: (1) "Radiological Analyses of Samples Collected for the Long-Term Ecological Monitoring for 2007 at the INL" and (2) "Organic, Inorganic, and Miscellaneous Classical Analyses of Samples Collected for the Long-Term Ecological Monitoring for 2007 at the INL." These SOWs (along with Table 1-3) will include the analytical methods and the project-required detection limits for each analysis type listed in the Appendix A sampling and analysis plan tables and field guidance forms. Project-specific detection limits are presented in Table 1-3. Any deviations from this information will be fully documented, and the laboratory will inform SAM and the technical lead of the deviations. Methods for other less-typical activities, such as histopathic inspection of deer mice liver and kidney samples, will follow the contracted laboratory's standard protocol. Bioassays (earthworm and seedling toxicity tests) will be performed to appropriate standards of the American Society for Testing and Materials or other accepted methods, as determined by the technical lead.

\subsubsection{Instrument Calibration Procedures}

Laboratory instruments are calibrated in accordance with each of the specified analytical methods. The laboratory quality assurance plan must include requirements for calibrations when specifications are not listed in analytical methods. Calibrations that are typically not called out in analytical methods include ancillary laboratory equipment and verification of reference standards used for calibration and standard preparation. Laboratory documentation includes calibration techniques and sequential calibration actions, performance tolerances provided by the specific analytical method, and dates and frequency of the calibrations. All analytical methods have specifications for equipment checks and instrument calibrations. The laboratory complies with all method-specific calibration requirements for all requested parameters. If failure of instrument calibration or equipment is detected, then the instrument will be recalibrated, and all affected samples will be analyzed using an acceptable calibration.

\subsubsection{Laboratory Records}

Laboratories that analyze the samples are required to keep records of sample receipt, processing, analysis, and data reporting. Sample management records must document sample receipt, sample handling and storage, and the sample analysis schedule. The records will be used to (a) verify that the $\mathrm{COC}$ and proper preservation are maintained, (b) document anomalies in the samples, (c) note proper log-in of samples into the laboratory, and (d) address procedures used to prioritize received samples, thereby ensuring that the holding time requirements are met.

The laboratory is responsible for maintaining documentation that demonstrates laboratory proficiency with each method as prescribed in standard operating procedures. Laboratory documentation includes sample preparation and analysis details, instrument standardization, detection and reporting limits, and test-specific quality control criteria. Any deviations from prescribed methods must be recorded properly. Quality assurance/quality control reports will include general quality control records on activities such as analyst training, instrument calibration, routine monitoring of analytical performance, and calibration verification. Project-specific analyses (e.g., blanks, spikes, calibration check samples, replicates, and splits performed in accordance with project requirements) may be performed and documented. Requirements for the quantity and types of quality assurance/quality control monitoring and associated reporting formats will be specified in the task-specific laboratory SOW.

\subsection{Data Management and Document Control}

\subsubsection{Data Reporting}

A basic ordering agreement standard deliverable is required for all data reported for this characterization project. The final data documentation package will conform to the criteria specified in ER-SOW-394. 
The environmental restoration SOW, prepared by the SAM Program, will be the standard for analytical data deliverable requirements for the laboratories used by the INL Site. All laboratories associated with this project will adhere to the document used to establish technical and reporting standards.

\subsubsection{Data Validation}

Analytical data validation is the comparison of analytical results with the requirements established by the analytical method. Validation involves evaluating all sample-specific information generated, from sample collection to receipt of the final data package. Data validation is used to determine whether analytical data are technically and legally defensible and reliable. The final product of the validation process is the validation report. The validation report communicates the quality and usability of the data to the decision-makers.

All data generated for this project will undergo independent validation. The SAM Program arranges for validation. Level B validation is requested for all sample data reports generated during this project. The validation report contains an itemized discussion of the validation process and results. Copies of the data forms annotated for qualification are attached to the validation report.

\subsubsection{Data Quality Assessment}

The data quality assessment process will be used to ascertain whether the data meet the project DQOs. Additional steps of the data quality assessment process may involve data plotting, testing for outlying data points, and other statistical analyses relative to the characterization project DQOs.

For this characterization plan, a 90\% completeness objective for all analyses has been established, because some sample locations might not contain enough material for all analyses requested. The completeness of the data is the number of samples collected and analyzed compared to the number of samples planned.

Precision is a measure of agreement among replicate measurements of the same property. Accuracy is a measure of the closeness of an individual measurement to the true value. Field and laboratory precision and accuracy should be within the limits and goals mentioned in the Quality Assurance Project Plan for Waste Area Groups 1, 2, 3, 4, 5, 6, 7, 10, and Removal Actions (DOE-ID 2006). Data results will be evaluated upon project completion to determine whether precision and accuracy goals have been met.

\subsubsection{Final Characterization Report}

A final characterization report will be prepared for this project in accordance with applicable program requirements. The final report will contain a summary of all sample data generated during this sampling effort. Appendixes containing all sample results may be attached. The final report will also describe the sample collection effort. A description of the data quality assessment process may also be included. The final report will discuss how the data will be used. The DQOs will be reviewed and evaluated to determine whether the characterization project's objectives have been met.

\subsubsection{Document Control}

Document control consists of clearly identifying all project-specific documents in an orderly manner, securely storing all project information, and controlling the distribution of all project information. Document control will ensure that controlled documents of all types related to the project receive appropriate levels of review, comment, and revision (as necessary). The project manager is responsible for properly maintaining project documents according to INL Site document control 
requirements. Upon completion of the characterization project, all project documentation and information will be transferred to compliant storage according to project, program, and company requirements. This information may include field logbooks, $\mathrm{COC}$ forms, laboratory data reports, engineering calculations and drawings, and final technical reports. 
4-14 


\section{HEALTH AND SAFETY REQUIREMENTS}

A hazard screening checklist was completed in accordance with the requirements of MCP-3562, "Hazard Identification, Analysis, and Control of Operational Activities," to identify hazards associated with this project. The hazards identified in the checklist, along with corresponding mitigation requirements, are documented in JSA-771 in accordance with MCP-3450, "Developing and Using Job Safety Analysis." By virtue of completing the JSA, technical input and approval were obtained from assigned environment, safety, health, and quality assurance personnel. In addition, hazards and mitigations have been integrated into TPR-145, "Biotic and Proximal Soil Sampling," which was developed for this project. Hazard identification, mitigation, and training for the majority of work planned in this document are covered under JSA-771 and TPR-145.

Additional training (40-hour hazardous waste operations and emergency response [HAZWOPER]) is required for work that is completed in CERCLA sites when potentially contaminated media are being sampled. The additional training and documentation for workers disturbing the media of concern at the sites discussed below are required to ensure compliance with regulations related to CERCLA. Hazard mitigation and PPE requirements are the same as those for similar work as listed in JSA-771 and TPR-145. Personnel who sample the potentially contaminated media at the specific locations listed below must be trained 40-hour HAZWOPER workers and must work under PLN-2128, "Miscellaneous Sites Cleanup Project Health and Safety Plan.” The specific locations include

- $\quad$ ARA and PBF (Figures 1-2 and 1-3)

- $\quad$ EBR-I and BORAX.

The potentially contaminated media include surface and subsurface soil at ARA, PBF, EBR-I and BORAX. Some sites at ARA, PBF, EBR-I, and BORAX are currently under institutional controls to restrict exposure to receptors. Plots have been located along areas with fenced restrictions. However, two plots are tentatively planned to be placed within the ARA-I and -II fenced area. Sampling at these plots will require HAZWOPER-trained personnel and some require Radiological Control support. The other plots are located at "No Action" areas under CERCLA because the potential contaminants do not pose an unacceptable risk to human health or the environment. HAZWOPER training is not required for workers completing other work (small mammal trapping, vegetation sampling, etc.) at these locations. 


$$
\text { 5-2 }
$$




\section{REFERENCES}

40 CFR 300, 2007, "National Oil and Hazardous Substances Pollution Contingency Plan," Code of Federal Regulations, Office of the Federal Register, June 2007.

40 CFR 300.440(a), 2007, "Applicability," Code of Federal Regulations, Office of the Federal Register, June 2007.

42 USC $\S 9601$ et seq., 1980, "Comprehensive Environmental Response, Compensation and Liability Act of 1980 (CERCLA/Superfund)," United States Code, December 11, 1980.

AEC, 1955, Press release, "Idaho Town Gets Atomic Power and Light in Nuclear Power Demonstration," United States Atomic Energy Commission, August 12, 1955,

http://web.archive.org/web/20041013172906/www.anlw.anl.gov/anlw_history/reactors/borax3pr.ht $\underline{\mathrm{ml}}$.

Belthoff, J. R., L. R. Power, and T. D. Reynolds, 1998, "Breeding Birds at the Idaho National Engineering Laboratory, 1985-1991," submitted to Great Basin Naturalist.

Chen-Northern, 1991, Industrial Waste Ditch Hydrogeologic Investigation U.S. Naval Reactors Facility Idaho National Engineering Laboratory Idaho, Volumes I through VII and Appendices, Chen-Northern Inc. for Westinghouse Electric Corporation, 1991.

DOE-ID, 1991, Federal Facility Agreement and Consent Order for the Idaho National Engineering Laboratory, Administrative Docket No. 1088-06-29-120, U.S. Department of Energy Idaho Operations Office; U.S. Environmental Protection Agency, Region 10; Idaho Department of Health and Welfare, December 4, 1991.

DOE-ID, 1999, Waste Area Group 5 Operable Unit 5-12 Comprehensive Remedial Investigation/Feasibility Study, DOE/ID-10607, U.S. Department of Energy Idaho Operations Office, January 1999.

DOE-ID, 2001, Comprehensive Remedial Investigation/Feasibility Study for Waste Area Groups 6 and 10 Operable Unit 10-04, DOE/ID-10807, Rev. 0, Volumes 1 and 2, U.S. Department of Energy Idaho Operations Office, August 2001.

DOE-ID, 2002, Record of Decision Experimental Breeder Reactor-I/Boiling Water Reactor Experiment Area and Miscellaneous Sites, DOE/ID-10980, U.S. Department of Energy Idaho Operations Office, U.S. Environmental Protection Agency, Idaho Department of Environmental Quality, November 2002.

DOE-ID, 2005, Idaho National Engineering and Environmental Laboratory Waste Acceptance Criteria, DOE/ID-10381, Rev. 21, U.S. Department of Energy Idaho Operations Office, January 2005.

DOE-ID, 2006, Quality Assurance Project Plan for Waste Area Groups 1, 2, 3, 4, 5, 6, 7, 10, and Removal Actions, DOE/ID-10587, Rev. 9, U.S. Department of Energy Idaho Operations Office, July 2006.

DOE-ID, 2007, ICDF Complex Waste Acceptance Criteria, DOE/ID-10881, Rev. 4, U.S. Department of Energy Idaho Operations Office, July 2007. 
EG\&G Idaho, 1984, Naval Reactors Facility Geotechnical Investigation, Volumes I \& II, EG\&G Idaho, Inc., for Knolls Atomic Power Laboratory, 1984.

Envirodyne Engineers, 1988, 1987/88 Phase I Closure Plan Sample Collection Report, NRF Industrial Waste Ditch Remedial Action Plan, Envirodyne Engineers, Inc., November 1988.

EPA, 2000, Guidance for the Data Quality Objectives Process, EPA QA/G-4, EPA/600/R-96/055, U.S. Environmental Protection Agency, August 2000. [Note: This document has been superseded by Guidance on Systematic Planning Using the Data Quality Objectives Process, EPA QA/G-4, EPA/240/B-06/001, February 2006. The basic structure of the data quality objectives process is unchanged but minor revisions have been made in the names of the seven steps of the process.]

ER-SOW-394, 2007, "Sample and Analysis Management Statement of Work for Analytical Services," Rev. 4, Idaho National Laboratory, March 2007.

Gabler, K. I., 1997, Distribution and Habitat Requirements of the Pygmy Rabbit (Brachylagus idahoensis) on the Idaho National Engineering and Environmental Laboratory, M.S. Thesis (unpublished), Idaho State University, Pocatello, Idaho.

GDE-279, 2004, “Surface Water Sampling for the Idaho Completion Project," Rev. 1, Idaho National Laboratory, Idaho Completion Project, April 2004.

GDE-282, 2004, "Decontaminating Ecological Sampling Equipment for the Idaho Completion Project," Rev. 0, Idaho National Laboratory, Idaho Completion Project, March 2004.

Hackett, W. R. and R. P. Smith, 1992, "Quaternary Volcanism Tectonics and Sedimentation in the Idaho National Engineering Laboratory Area," pp. 1-18 in J. R. Wilson, editor, Field Guide to Geologic Excursions in Utah and Adjacent Areas of Nevada, Idaho, and Wyoming, Miscellaneous Publication 92-3, Utah Geological Survey, Salt Lake City, Utah.

Hampton, N. L., R. C. Rope, J. M. Glennon, and K. S. Moore, 1995, A Preliminary Survey of the National Wetlands Inventory as Mapped for the Idaho National Engineering Laboratory, INEL-95/0101, Rev. 0, Idaho National Engineering Laboratory, February 1995.

Haney, T., and R. VanHorn, 2003, Long-term Ecological Monitoring Field Sampling Plan for 2003, INEEL/EXT-02-01546, Rev. 0, Idaho National Engineering and Environmental Laboratory, May 2003.

Haney, T., R. VanHorn, and C. Fordham, 2004, Long-Term Ecological Monitoring Field Sampling Plan for 2004, ICP/EXT-04-00165, Rev. 0, Idaho Completion Project, June 2004.

Haney, T., R. VanHorn, G. White, and R. Rope, 2005, Long-Term Ecological Monitoring Field Sampling Plan for 2005, ICP/EXT-05-00778, Rev. 0, Idaho Completion Project, May 2005.

Haney, T., and R. VanHorn, 2006, Long-Term Ecological Monitoring Field Sampling Plan for 2006, ICP/EXT-06-01130, Rev. 0, Idaho Cleanup Project, May 2006.

Holdren, K., R. Filemyr, and D. Vetter, 1995, Remedial Investigation/Feasibility Study Report for Operable Units 5-05 and 6-01 (SL-1 and BORAX-I Burial Grounds), INEL-95/0027 (formerly EGG-ER-11238), Rev. 0, Lockheed Idaho Technologies Company, Idaho National Engineering Laboratory, March 1995. 
INEEL, 2002, Ancillary Basis for Risk Analysis of the Subsurface Disposal Area, INEEL/EXT-02-01125, Idaho National Engineering and Environmental Laboratory, September 2002.

INEEL, 2004, Long-Term Ecological Monitoring Plan for the Idaho National Engineering and Environmental Laboratory, INEEL/EXT-02-01191, Rev. 1, Idaho National Engineering and Environmental Laboratory, January 2004.

JSA-771, 2006, “Long-Term Ecological Monitoring and Surveillance,” Rev. 4, Idaho National Laboratory, Idaho Cleanup Project, April 27, 2006.

Marsh, C. M., C. L. Fordham, and R. A. Loucks, 1998, "Tooele Army Depot Revised Final Site-Wide Ecological Risk Assessment," Volumes I-IV, SFIM-AEC-RP-CR-97056, Rust Environment and Infrastructure, February 1998.

MCP-135, 2007, “Document Management," Rev. 23, Idaho National Laboratory, Idaho Cleanup Project, May 2007

MCP-1192, 2006, "Chain-of-Custody and Sample Labeling for ICP CERCLA and Removal Action Sampling Activities,” Rev. 3, Idaho National Laboratory, Idaho Cleanup Project, September 2006.

MCP-1193, 2006, "Handling and Shipping Samples for ICP CERCLA and Removal Action Sampling Activities," Rev. 3, Idaho National Laboratory, Idaho Cleanup Project, September 2006.

MCP-1194, 2006, “Logbook Practices for ICP CERCLA and Removal Action Projects," Rev. 3, Idaho National Laboratory, Idaho Cleanup Project, September 2006.

MCP-3450, 2006, "Developing and Using Job Safety Analysis," Rev. 4, Manual 14A-Safety and Health-Occupational Safety and Fire Protection, Idaho National Laboratory, Idaho Cleanup Project, December 2006.

MCP-3562, 2006, "Hazard Identification, Analysis, and Control of Operational Activities," Rev. 10, Manual 9-Operations, Idaho National Laboratory, Idaho Cleanup Project, December 2006.

MCP-9439, 2007, "Environmental Sampling Activities at the INL," Rev. 5, Manual 8-Environmental Protection and Compliance, Idaho National Laboratory, Idaho Cleanup Project, April 2007.

NRF, 1997, Final NRF Comprehensive Remedial Investigation/Feasibility Study Waste Area Group 8 Naval Reactors Facility Idaho Falls, Idaho, Document ID: 10432, Volume 1, Part I, "Remedial Investigation Report," Naval Reactors Facility, October 1997.

Olson, G. L., D. J. Jeppesen, and R. D. Lee, 1995, The Status of Soil Mapping for the Idaho National Engineering Laboratory, INEL-95/0051, EG\&G Idaho, January 1995.

PLN-2128, 2007, "Miscellaneous Sites Cleanup Project Health and Safety Plan,” Rev. 3, Idaho National Laboratory, Idaho Cleanup Project, May 2007.

PRD-5030, 2007, "Environmental Requirements for Facilities, Processes, Materials and Equipment," Rev. 7, Manual 8-Environmental Protection and Compliance, Idaho National Laboratory, Idaho Cleanup Project, January 2007.

SW-846, 2002, Test Methods for Evaluating Solid Wastes Physical/Chemical Methods, U.S. Environmental Protection Agency, Office of Solid Waste and Emergency Response, August 2002. 
TEM-104, 2007, “Model for Preparation of Characterization Plans," Rev. 4, Idaho National Laboratory, Idaho Cleanup Project, April 2007.

TPR-145, 2006, "Biotic and Proximal Soil Sampling," Rev. 4, Idaho National Laboratory, Idaho Cleanup Project, May 2006.

USFWS, April 30, 1996, Letter from the U.S. Fish and Wildlife Service to T. Reynolds, Environmental Science and Research Foundation, SP\# 1-4-96-SP-185, update to SP\#1-4-95-255, File \#506.0000.

USFWS, July 16, 1997, Letter from the U.S. Fish and Wildlife Service to T. Reynolds, Environmental Science and Research Foundation, SP\# 1-4-97-SP-242, update to SP\#1-4-96-185, File \#506.000. 


\section{Appendix A}

\section{Sampling and Analysis Plan Tables}




$$
\text { A-2 }
$$


SAP Number: ICPIEXT-06-01130
Date: $06 / 11 / 2007$
Plan Table Revision: 1.0
Project: LONG TERM ECOLOGICAL MONITORING FY 2007
Project Manager: HANEY, T.J.

Sampler: Haney, T.J.

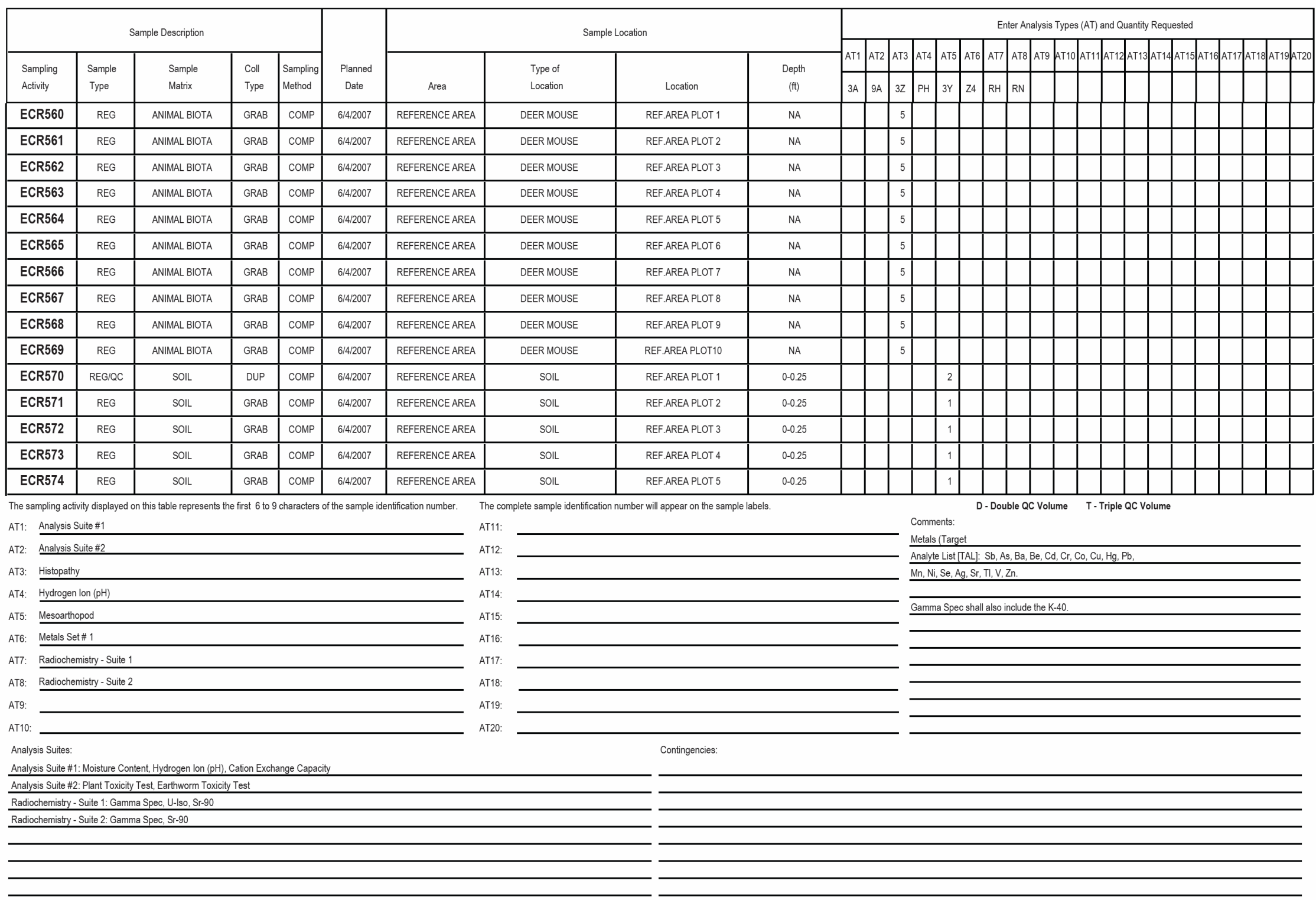


SAP Number: ICPIEXT-06-01130

Date: $\quad$ 06/11/2007 Plan Table Revision: 1.0 Project: LONG TERM ECOLOGICAL MONITORING FY 2007

oject Manager: $\quad$ HANEY, T. J.

Sampler: Haney, T. J.

SMO Contact: CHAMBERS, L.S.

\begin{tabular}{|c|c|c|c|c|c|c|c|c|c|c|c|c|c|c|c|c|c|c|c|c|c|c|}
\hline \multicolumn{5}{|c|}{ Sample Description } & \multirow{3}{*}{$\begin{array}{l}\text { Planned } \\
\text { Date }\end{array}$} & \multicolumn{5}{|c|}{ Sample Location } & \multicolumn{12}{|c|}{ Enter Analysis Types (AT) and Quantity Requested } \\
\hline Sampling & & Sample & Coll & | Sampling| & & \multirow[b]{2}{*}{ Area } & \multirow{2}{*}{\multicolumn{2}{|c|}{$\begin{array}{l}\text { Type of } \\
\text { Location }\end{array}$}} & \multirow[b]{2}{*}{ Location } & \multirow{2}{*}{$\begin{array}{l}\text { Depth } \\
\text { (t) }\end{array}$} & \multirow{2}{*}{\begin{tabular}{|l|} 
AT1 \\
$3 \mathrm{~A}$
\end{tabular}} & \multirow{2}{*}{\begin{tabular}{|l|} 
AT2 \\
$9 \mathrm{~A}$
\end{tabular}} & \multirow{2}{*}{\begin{tabular}{|l|} 
AT4 \\
PH \\
\end{tabular}} & \multirow{2}{*}{\begin{tabular}{|l|} 
AT5 \\
$3 Y$
\end{tabular}} & \begin{tabular}{|l|l|} 
& AT6 \\
\end{tabular} & \begin{tabular}{|l|l|} 
AT & AT \\
\end{tabular} & \multirow{2}{*}{ AT9 $4 T 11$} & \multirow{2}{*}{\begin{tabular}{l|l|l} 
T110 & AT11 & AT12 \\
& &
\end{tabular}} & 12 AT13 AT14 & \multirow{2}{*}{14 AT15 AT } & \multirow{2}{*}{\multicolumn{2}{|c|}{17 AT18 $\left.A T 19\right|^{-A T 20}$}} \\
\hline Activity & Type & Matrix & Type & Method & & & & & & & & & & & 24 F & \begin{tabular}{|l|l|}
$\mathrm{RH}$ & $\mathrm{RN}$ \\
\end{tabular} & & & & & & \\
\hline ECR575 & REG & soll & GRAB & сOMP & 6/4/2007 & REFERENCE AREA & & SOIL & REF.AREA PLOT 6 & $0-0.25$ & & & & 1 & & & & & & & & \\
\hline ECR576 & REG & soll & GRAB & COMP & 6/4/2007 & REFERENCE AREA & & SOlL & REF.AREA PLOT 7 & $0-0.25$ & & & & 1 & & & & & & & & \\
\hline ECR577 & REG & soll & GRAB & сомР & 6/422007 & REFERENCE AREA & & SOIL & REF.AREA PLOT 8 & $0-0.25$ & & & & 1 & & & & & & & & \\
\hline ECR578 & REG & soll & GRAB & COMP & 6/4/2007 & REFERENCE AREA & & SOIL & REF.AREA PLOT 9 & $0-0.25$ & & & & $1 \mid$ & & & & & & & & \\
\hline ECR579 & REG & soll & GRAB & сомР & 6/422007 & REFERENCE AREA & & SOIL & REF.AREA PLOT10 & $0-0.25$ & & & & 1 & & & & & & & & \\
\hline ECR580 & REG/QC & PLANT BIOTA & DUP & сOMP & 6/42007 & MACKAY RES & & PLANT & MACKAY RES 1 & NA & & & & & 2 & 2 & & & & & & \\
\hline ECR581 & REG & PLANT BIOTA & GRAB & сOMP & 6/4/2007 & MACKAY RES & & PLANT & MACKAY RES 2 & NA & & & & & 1 & 1 & & & & & & \\
\hline ECR582 & REG & PLANT BIOTA & GRAB & COMP & 6/42007 & MACKAY RES & & PLANT & MACKAY RES 3 & NA & & & & & 1 & 1 & & & & & & \\
\hline ECR583 & REG & PLANT BIOTA & GRAB & сомР & 6/4/2007 & MACKAY RES & & PLANT & MACKAY RES 4 & NA & & & & & 1 & 1 & & & & & & \\
\hline ECR584 & REG & PLANT BIOTA & GRAB & сомР & 6/4/2007 & MACKAY RES & & PLANT & MACKAY RES 5 & NA & & & & & 1 & 1 & & & & & & \\
\hline ECR585 & REG/QC & WATER & DUP & сомP & 6/4/2007 & MACKAY RES & & WATER & MACKAY RES 1 & NA & & & 2 & & 2 & 2 & & & & & & \\
\hline ECR586 & REG & WATER & GRAB & COMP & 6/4/2007 & MACKAY RES & & WATER & MACKAY RES 2 & NA & & & 1 & & 1 & 1 & & & & & & \\
\hline ECR587 & REG & WATER & GRAB & COMP & 6/4/2007 & MACKAY RES & & WATER & MACKAY RES 3 & NA & & & 1 & & 1 & 1 & & & & & & \\
\hline ECR588 & REG & WATER & GRAB & COMP & 6/4/2007 & MACKAY RES & & WATER & MACKAY RES 4 & NA & & & 1 & & 1 & 1 & & & & & & \\
\hline ECR589 & REG & WATER & GRAB & сомP & 6/4/2007 & MACKAY RES & & WATER & MACKAY RES 5 & NA & & & 1 & & 1 & 1 & & & & & & \\
\hline $\begin{array}{l}\text { The sampling a } \\
\text { AT1: Analysis }\end{array}$ & $\begin{array}{l}\text { ity displayed } \\
\text { uite \#1 }\end{array}$ & nis table represent & irst 6 to 9 & characters & ne sample i & :ntification number. & $\begin{array}{l}\text { The com } \\
\text { AT11. }\end{array}$ & nplete sample id & eer will appear on the sar & & & & Comme & & & Double QC & c Volume & T-Triple & le QC Volume & & & \\
\hline AT2: Analysis & uite \#2 & & & & & & AT12: & & & & & & Metals & (Target & & & & & & & & \\
\hline AT3: Histopal & & & & & & & AT13: & & & & & & $-\frac{\text { Analyte }}{\mathrm{Mn}, \mathrm{Ni}}$ & e List T] & TALI: $S$ S & $\mathrm{sb}, \mathrm{As}, \mathrm{Ba}, \mathrm{E}$ & $\mathrm{Be}, \mathrm{Cd}$ & Cu, Hg, & & & & \\
\hline AT4: Hydroge & $\operatorname{lon}(\mathrm{pH})$ & & & & & & AT14: & & & & & & & & & & & & & & & \\
\hline AT5: Mesoar & & & & & & & AT15: & & & & & & Gamms & na Spec & cshall a & also include & e the $k-40$. & & & & & \\
\hline AT6: Metals S & & & & & & & AT16: & & & & & & & & & & & & & & & \\
\hline AT7: Radioch & nistry - Sute 1 & & & & & & AT17: & & & & & & & & & & & & & & & \\
\hline AT8: Radioch & nistry - Suite 2 & & & & & & AT18: & 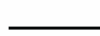 & & & & & & & & & & & & & & \\
\hline AT9: & & & & & & & AT19: & & & & & & & & & & & & & & & \\
\hline AT10: & 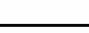 & & & & & & AT20: & & & & & & & & & & & & & & & \\
\hline $\begin{array}{l}\text { Analysis Suites } \\
\text { Analysis Suite }\end{array}$ & Moisture Con & t. Hydrogen lon (pt & Sation Exch & ange Capac & & & & & Contingencies: & & & & & & & & & & & & & \\
\hline Analysis Suite: & Plant Toxicity & st, Earthworm Tox & & & & & & & & & & & & & & & & & & & & \\
\hline Radiochemistry & Suite 1: Gamn & Spec, U-lso, Sr-90 & & & & & & & & & & & & & & & & & & & & \\
\hline Radiochemistry & Suite 2: Gamn & peec, Sr-90 & & & & & & & & & & & & & & & & & & & & \\
\hline
\end{tabular}


SAP Number: ICPIEXT-06-01130
Date: $\quad 06 / 11 / 2007$
Plan Table Revision: 1.0
Project: LONG TERM ECOLOGICAL MONITORING FY 2007
Project Manager: HANEY, T.J

Sampler. Haney, T.J.

Enter Analysis Types (AT) and Quantity Requested

\begin{tabular}{|c|c|c|c|c|c|c|c|c|c|c|c|c|c|c|c|c|c|c|c|c|c|c|c|c|}
\hline & & pple Description & & & & & & & & & & & & & & & rAna & Alysis Types & (AT) a & and Quantit & ity Reque & uested & & \\
\hline & & & 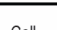 & & Planoed & & Type of & & & AT1 & AT2 & AT3 & AT4 & AT5 & AT6 & AT7 & AT8 & AT9 $A T+10$ & AT11 & AT12 $A T 13$ & 3 AT14 & 4 AT15 AT1 & 16 AT17/AT18 & AT19AT20 \\
\hline Activity & Type & Matrix & Type & Method & Date & Area & Location & Location & (ft) & $3 \mathrm{~A}$ & 9A & $3 z$ & $\mathrm{PH}$ & $3 Y$ & 24 & $\mathrm{RH}$ & $\mathrm{RN}$ & & & & & & & \\
\hline ECR590 & REG/QC & SEDIMENT & DUP & COMP & 6/4/2007 & MACKAY RES & SEDIMENT & MACKAY RES 1 & $\mathrm{NA}$ & & & & 2 & & 2 & & 2 & & & & & & & \\
\hline ECR591 & REG & SEDIMENT & GRAB & COMP & 6/4/2007 & MACKAY RES & SEDIMENT & MACKAY RES 2 & NA & & & & 1 & & 1 & & 1 & & & & & & & \\
\hline ECR592 & REG & SEDIMENT & GRAB & COMP & 6/4/2007 & MACKAY RES & SEDIMENT & MACKAY RES 3 & NA & & & & 1 & & 1 & & 1 & & & & & & & \\
\hline ECR593 & REG & SEDIMENT & GRAB & COMP & 6/4/2007 & MACKAY RES & SEDIMENT & MACKAY RES 4 & $\mathrm{NA}$ & & & & 1 & & 1 & & 1 & & & & & & & \\
\hline ECR594 & REG & SEDIMENT & GRAB & COMP & 6/4/2007 & MACKAY RES & SEDIMENT & MACKAY RES 5 & $\mathrm{NA}$ & & & & 1 & & 1 & & 1 & & & & & & & \\
\hline ECR595 & REG & ANIMAL BIOTA & GRAB & сомP & 6/412007 & ARAPBF & DEER MOUSE & PBF PLOT 1 & $\mathrm{NA}$ & & & 5 & & & 1 & 1 & & & & & & & & \\
\hline ECR596 & REG & ANIMAL BIOTA & GRAB & сомP & 6/412007 & ARAPBFF & DEER MOUSE & PBF PLOT 2 & NA & & & 5 & & & 1 & 1 & & & & & & & & \\
\hline ECR597 & REG & ANIMAL BIOTA & GRAB & сомP & 6/412007 & ARAPBF & DEER MOUSE & PBF PLOT 3 & $\mathrm{NA}$ & & & 5 & & & 1 & 1 & & & & & & & & \\
\hline ECR598 & RFG & ANIMAI RIOTA & GRAB & \begin{tabular}{|l|} 
COMP \\
\end{tabular} & 6/4/120007 & ARA/PBF & DFFR MOUSF & PRFPIOT 4 & $\mathrm{NA}$ & & & 5 & & & 1 & 1 & & & & & & & & \\
\hline ECR599 & REG & ANIMAL BIOTA & GRAB & COMP & 6/4/2007 & ARAPBF & DEER MOUSE & PBF PLOT 5 & NA & & & 5 & & & 1 & 1 & & & & & & & & \\
\hline ECR600 & REG & ANIMAL BIOTA & GRAB & COMP & 6/4/2007 & ARAPBF & DEER MOUSE & ARA PLOT 6 & $\mathrm{NA}$ & & & 5 & & & 1 & 1 & & & & & & & & \\
\hline ECR601 & REG & ANIMAL BIOTA & GRAB & COMP & 6/4/2007 & ARAPBF & DEER MOUSE & ARA PLOT 7 & NA & & & 5 & & & 1 & 1 & & & & & & & & \\
\hline ECR602 & REG & ANIMAL BIOTA & GRAB & COMP & 6/4/2007 & ARAPBFF & DEER MOUSE & ARA PLOT 8 & NA & & & 5 & & & 1 & 1 & & & & & & & & \\
\hline ECR603 & REG & ANIMAL BIOTA & GRAB & COMP & 6/4/2007 & ARAPBFF & DEER MOUSE & ARA PLOT 9 & $\mathrm{NA}$ & & & 5 & & & 1 & 1 & & & & & & & & \\
\hline ECR604 & REG & ANIMAL BIOTA & GRAB & COMP & 6/4/2007 & ARAPBPF & DEER MOUSE & ARA PLOT 10 & $\mathrm{NA}$ & & & 5 & & & 1 & 1 & & & & & & & & \\
\hline
\end{tabular}

The sampling activity displayed on this table represents the first 6 to 9 characters of the sample identification number. The complete sample identification number will appear on the sample labels

AT1: Analysis Suite\#1

AT2: Analysis Suite\#2

AT3: Histopathy

AT4: Hydrogen lon $(\mathrm{pH})$

AT5: Mesoarthopod

AT6: Metals Set\# 1

AT7: Radiochemistry-Suite 1

AT8: Radiochemistry - Suite 2

AT9:

AT10:

Analysis Suites:

The comp
AT11:

Comments:

- Double QC Volume T- Triple QC Volume

Comment.

Analyte List[TAL]: Sb, As, Ba, Be, Cd, Cr, Co, Cu, Hg, Pb

$\mathrm{Mn}, \mathrm{Ni}, \mathrm{Se}, \mathrm{Ag}, \mathrm{Sr}, \mathrm{Tl}, \mathrm{V}, \mathrm{Zn}$.

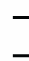

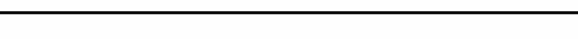

Gamrisp

Gamma Spec shall also include the $K-40$.

Analysis Suite \#1: Moisture Content, Hydrogen lon (pH), Cation Exchange Capacity

Analysis Suite \#2: Plant Toxicity Test, Earthworm Toxicity Test

Radiochemistry - Suite 1: Gamma Spec, U-lso, Sr-90

Radiochemistry- Suite 2: Gamma Spec, Sr-90 
Plan Table Number: LTS_ECM_2007

SAP Number, ICPIEXT-06-01130

Date: $06 / 1112007$ Plan Table Revision: 1.0 Project: LONG TERM ECOLOGICAL MONITORING FY 2007

Project Manager: $\quad$ HANEY, T.J.

Sampler. Haney, T.J.

SMO Contact: CHAMBERS, L.S.

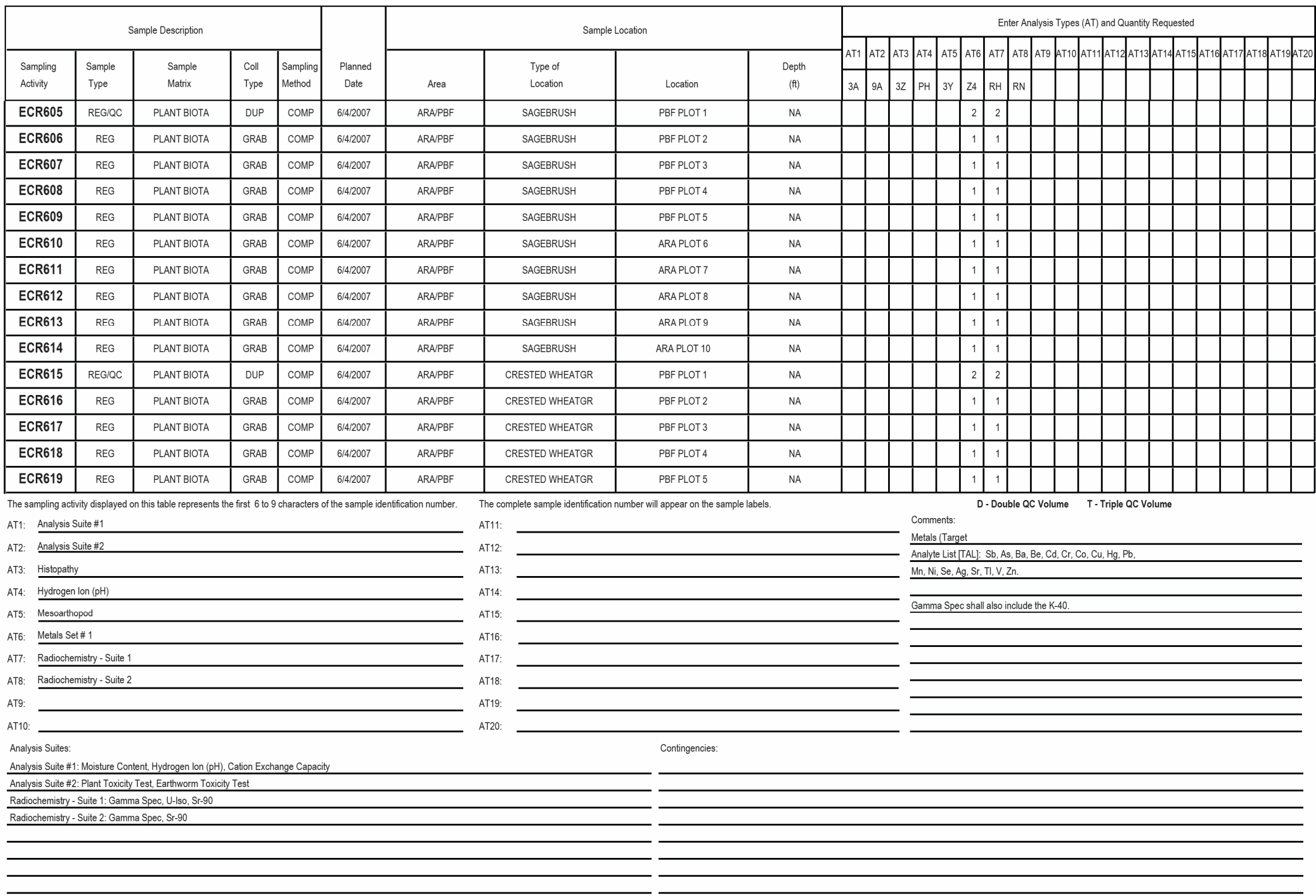


Plan Table Number: LTS_ECM_2007

SAP Number: ICPIEXT-06-01130

sampler. Haney, T. J.

Date: $06 / 1112007$ Plan Table Revision: 1.0 Project: LONG TERM ECOLOGICAL MONITORING FY 2007 Project Manager: HANEY, T.J.

SMO Contact: CHAMBERS, L. S.

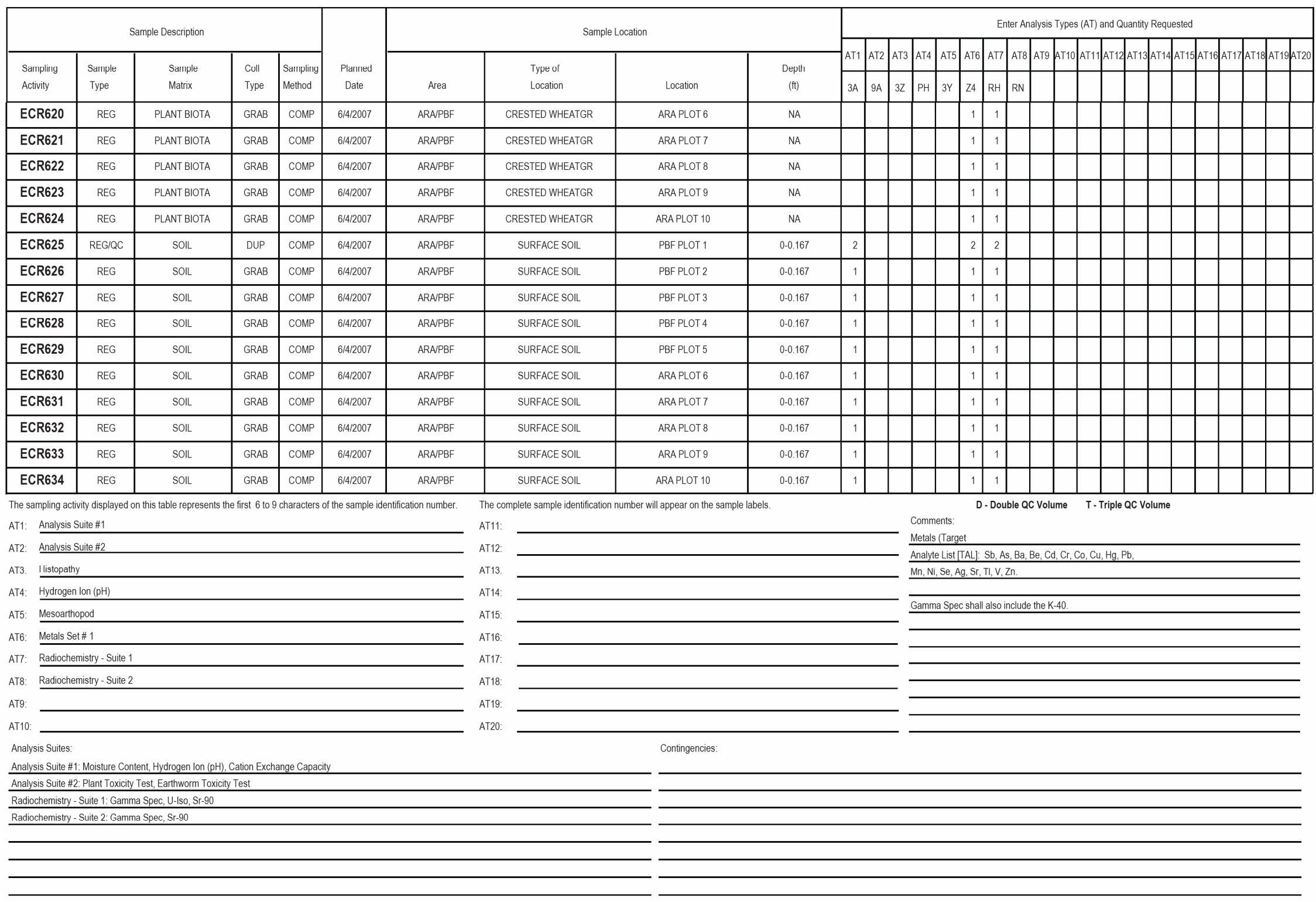


SAP Number: ICPIEXT-06-01130
Date: $06 / 11 / 2007$
Plan Table Revision: 1.0
Project: LONG TERM ECOLOGICAL MONITORING FY 2007
Project Manager. HANEY, T. J.

Sampler. Haney $T$.

\begin{tabular}{|c|c|c|c|c|c|c|c|c|c|c|c|c|c|c|c|c|c|c|c|c|c|c|c|c|}
\hline \multicolumn{5}{|c|}{ Sample Description } & \multirow{3}{*}{$\begin{array}{l}\text { Planned } \\
\text { Date }\end{array}$} & \multicolumn{4}{|c|}{ Sample Location } & \multicolumn{15}{|c|}{ Enter Analysis Types (AT) and Quantity Requested } \\
\hline Sampling & Sample & Sample & Coll & Sampling & & & & & Depth & AT1 & AT2 & AT3 & AT4 & AT5 & A76 & T7 AT & {$[8 \mid \mathrm{A}$} & 9 a 410 & AT11 AT12 & 12 AT13 AT1 & T14 AT15 A & |AT16|AT17 & 17 AT18 AT & AT19 AT20 \\
\hline Activity & Type & Matrix & Type & Method & & Area & Location & Location & (ft) & $3 A$ & $9 \mathrm{~A}$ & 32 & $\mathrm{PH}$ & 3Y & Z4 & $\mathrm{RH}$ RI & & & & & & & & \\
\hline ECR635 & REG/QC & soll & DUP & COMP & 6/4/2007 & ARAPBF & SUBSURFACE SOIL & PBF PLOT 1 & $0.167-2$ & 2 & & & & & 2 & 2 & & & & & & & & \\
\hline ECR636 & REG & SOIL & GRAB & COMP & 6/4/2007 & ARAPBF & SUBSURFACE SOIL & PBF PLOT2 & $0.167-2$ & 1 & & & & & 1 & 1 & & & & & & & & \\
\hline ECR637 & REG & SOIL & GRAB & COMP & $66 / 1 / 2007$ & ARAPBF & SUBSURFACE SOIL & PBF PLOT 3 & $0.167-2$ & 1 & & & & & 1 & 1 & & & & & & & & \\
\hline ECR638 & REG & soll & GRAB & COMP & 6/4/2007 & ARAPBF & SUBSURFACE SOIL & PBF PLOT 4 & $0.167-2$ & 1 & & & & & 1 & 1 & & & & & & & & \\
\hline ECR639 & REG & soll & GRAB & COMP & 6/4/2007 & ARAPBF & SUBSURFACE SOIL & PBF PLOT 5 & $0.167-2$ & 1 & & & & & 1 & 1 & & & & & & & & \\
\hline ECR640 & REG & soll & GRAB & COMP & 6/4/2007 & ARAPBF & SUBSURFACE SOIL & ARAPLOT 6 & $0.167-2$ & 1 & & & & & 1 & 1 & & & & & & & & \\
\hline ECR641 & REG & soll & GRAB & COMP & 6/4/2007 & ARAPBF & SUBSURFACE SOIL & ARA PLOT 7 & $0.167-2$ & 1 & & & & & 1 & 1 & & & & & & & & \\
\hline ECR642 & REG & soll & GRAB & COMP & 6/4/2007 & ARAPBF & SUBSURFACE SOIL & ARA PLOT 8 & $0.167-2$ & 1 & & & & & 1 & 1 & & & & & & & & \\
\hline ECR643 & REG & soll & GRAB & COMP & 6/4/2007 & ARAPBF & SUBSURFACE SOIL & ARA PLOT 9 & $0.167-2$ & 1 & & & & & 1 & 1 & & & & & & & & \\
\hline ECR644 & REG & SOIL & GRAB & COMP & 6/4/2007 & ARAPBF & SUBSURFACE SOIL & ARAPLOT 10 & $0.167-2$ & 1 & & & & & 1 & 1 & & & & & & & & \\
\hline ECR645 & REG/QC & SOIL & DUP & COMP & 6/4/2007 & ARAPBF & Soll & PBF PLOT 1 & $0-0.25$ & & & & & 2 & & & & & & & & & & \\
\hline ECR646 & REG & soll & GRAB & COMP & 6/4/2007 & ARAPBF & soll & PBF PLOT 2 & $0-0.25$ & & & & & 1 & & & & & & & & & & \\
\hline ECR647 & REG & soll & GRAB & COMP & 6/4/2007 & ARAPBF & soll & PBF PLOT 3 & $0-0.25$ & & & & & 1 & & & & & & & & & & \\
\hline ECR648 & REG & SOIL & GRAB & сомP & 6/4/2007 & ARAPBF & soll & PBF PLOT 4 & $0-0.25$ & & & & & 1 & & & & & & & & & & \\
\hline ECR649 & REG & soll. & GRAB & COMP & 6/4/2007 & ARAPBF & Soll. & PBF PLOT 5 & $0-0.25$ & & & & & 1 & & & & & & & & & & \\
\hline
\end{tabular}

The sampling activity displayed on this table represents the first 6 to 9 characters of the sample identification number

AT1. Analysis Suite \#

The complete sample identification number will appear on the sample labels

AT2: Analysis Suite \#2

AT3: Histopathy

AT4: Hydrogen lon $(\mathrm{pH})$

AT5: Mesoarthopod

AT6: Metals Set\#1

AT7: Radiochemistry - Suite 1

AT8: Radiochemistry - Suite 2

AT9:

AT10.

Analysis Suites:

AT11:

AT12:

AT15:

AT17:

AT18:

AT19

AT20

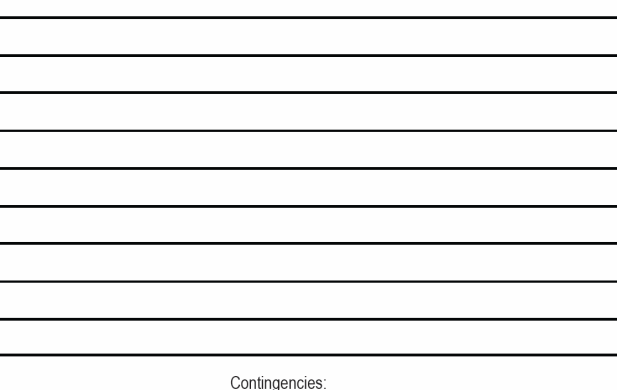

Conngenties
Comments:

Analyte List [TAL: Sb, As, Ba, Be, Cd, Cr, Co, Cu, Hg, Pb

Mn Ni Se Aa Sr Ti V

\section{Gamma Spec shall also include the $K-40$}

Analysis Sute \#1: Moisture Content, Hydrogen lon (pH), Cation Exchange Capacity

Analysis Suite \#2: Plant Toxicily Test, Earthworm Toxicily Tesi

Radiochemistry - Suite 1: Gamma Spec, U-Iso, Sr-90

Radiochemistry - Suite 2: Gamma Spec, St-90 
Plan Table Number: LTS_ECM_2007

SAP Number: ICPIEXT-06-01130

Date: $06 / 112007 \quad$ Plan Table Revision: $1.0 \quad$ Project. LONG TERM ECOLOGICAL MONITRRING FY 2007

Project Manager: HANEY, T.J.

Sampler. Haney $T$ J

SMO Contact. CHAMBERS, L.S.

Enter Analysis Types (AT) and Quantity Reguested

\begin{tabular}{|c|c|c|c|c|c|c|c|c|c|c|c|c|c|c|c|c|c|c|c|c|c|c|c|}
\hline \multicolumn{5}{|c|}{ Sample Description } & \multirow{3}{*}{$\begin{array}{l}\text { Planned } \\
\text { Date }\end{array}$} & \multicolumn{4}{|c|}{ Sample Location } & \multicolumn{14}{|c|}{ Enter Analysis Types (AT) and Quantity Requested } \\
\hline Sampling & Sample & Sample & Coll & Sampling & & & Type of & & Depth & AT1 & AT2 & AT3 A & AT4 & AT5 A7 & \begin{tabular}{l|l|}
$T 6$ & AT7 \\
\end{tabular} & ATR A & AT9 4 AT & T10|AT11 & 1 AT12 AT13 & 13 AT14 AT15 & 15 AT16 AT & $A T 17$ AT1 18 & AT19AT20 \\
\hline Activity & Type & Matrix & Type & Method & & Area & Location & Location & (t) & $3 \mathrm{~A}$ & 9A & 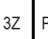 & $\mathrm{PH}$ & 3Y $z$ & $\begin{array}{lll}24 & \mathrm{RH} \\
\end{array}$ & RN & & & & & & & \\
\hline ECR650 & REG & soll & GRAB & COMP & 61422007 & ARAPBF & SOIL & ARA PLOT 6 & $0-0.25$ & & & & & 1 & & & & & & & & & \\
\hline ECR651 & REG & soll & GRAB & | COMP & 6142007 & ARAPBF & SOIL & ARA PLOT 7 & $0-0.25$ & & & & & 1 & & & & & & & & & \\
\hline ECR652 & REG & soll & GRAB & COMP & $6 / 412007$ & ARAPBF & SOIL & ARA PLOT 8 & $0-0.25$ & & & & & 1 & & & & & & & & & \\
\hline ECR653 & REG & soll & GRAB & СOMP & 6/412007 & ARAPBF & soll & ARA PLOT 9 & $0-0.25$ & & & & & 1 & & & & & & & & & \\
\hline ECR654 & REG & SOIL & GRAB & сомP & $6 / 4 / 2007$ & ARAPBF & SOIL & ARA PLOT 10 & $0-0.25$ & & & & & 1 & & & & & & & & & \\
\hline ECR655 & REG/QC & soll & DUP & COMP & 61412007 & ARAPBF & SOIL & PBF PLOT 1 & $0-1$ & & 2 & & & & & & & & & & & & \\
\hline ECR656 & REG & SOIL & GRAB & СOMP & 6/412007 & ARAPBF & SOlL & PBF PLOT 2 & $0-1$ & & 1 & & & & & & & & & & & & \\
\hline ECR657 & REG & SOIL & GRAB & COMP & $6 / 4120007$ & ARAPBF & SOIL & PBF PLOT 3 & $0-1$ & & 1 & & & & & & & & & & & & \\
\hline ECR658 & REG & SOIL & GRAB & сOMP & 61/42007 & ARAPBF & SOIL & PBF PLOT 4 & $0-1$ & & 1 & & & & & & & & & & & & \\
\hline ECR659 & REG & SOIL & GRAB & СOMP & 61412007 & ARA/PBF & SOIL & PBF PLOT 5 & $0-1$ & & 1 & & & & & & & & & & & & \\
\hline ECR660 & REG & SOIL & GRAB & COMP & 61412007 & ARAPBF & SOIL & ARA PLOT 6 & $0-1$ & & 1 & & & & & & & & & & & & \\
\hline ECR661 & REG & SOIL & GRAB & COMP & 6142000 & ARAPBF & SOIL & ARA PLOT 7 & $0-1$ & & 1 & & & & & & & & & & & & \\
\hline ECR662 & REG & SOIL & GRAB & \begin{tabular}{|c|} 
сомMP \\
\end{tabular} & 61412007 & ARAPBF & SOIL & ARA PLOT 8 & $0-1$ & & 1 & & & & & & & & & & & & \\
\hline ECR663 & REG & SOIL & GRAB & COMP & $61 / 42007$ & ARAPBF & SOIL & ARA PLOT 9 & $0-1$ & & 1 & & & & & & & & & & & & \\
\hline ECR664 & REG & SOIL & GRAB & COMP & 61412007 & ARAPBF & SOIL & ARA PLOT 10 & $0-1$ & & 1 & & & & & & & & & & & & \\
\hline
\end{tabular}

The sampling activity displayed on this table representsts the first 6 to 9 characters of the sample identification number. The complete sample identification number will appear on the sample labels

AT1: Analysis Suite\#1

AT2: Analysis Suite \#2

AT11:

AT3: Histopathy

AT4: Hydrogen lon $(\mathrm{pH})$

AT5: Mesoarthopod

AT6: Metals Set\# 1

AT7: Radiochemistry - Suite 1

AT8: Radiochemistry - Suite 2

AT9:

AT10:

Analysis Suites:

Comments:

Metals (Target

Analyete List TTAL]: Sb, As, Ba, Be, Cd, Cr, Co, Cu, Hg, Pb

Mn. Ni Se, Ag. Sr Ti. V Zn.

Gamma Spec shall also include the K-40

Analysis Suite \#1: Moisture Content, Hydrogen lon (pH), Cation Exchange Capacity

Analysis Suite \#2: Plant Toxicity Test, Earthworm Toxicity Test

Radiochemistry - Suite 1: Gamma Spec, U-lso, Sr-90

Radiochemistry - Suite 2: Gamma Spec, Sr-90

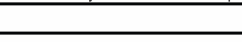


Plan Table Number: LTS_ECM_2007

SAP Number: ICPIEXT-06-01130

Sampler: Haney, T. J.

Date: $06 / 112007$ Plan Table Revision: $1.0 \quad$ Project: LONG TERM ECOLOGICAL MONITORING FY $2007 \quad$ Project Manager: HANEY, T.J

SMO Contact: CHAMBERS, L.S

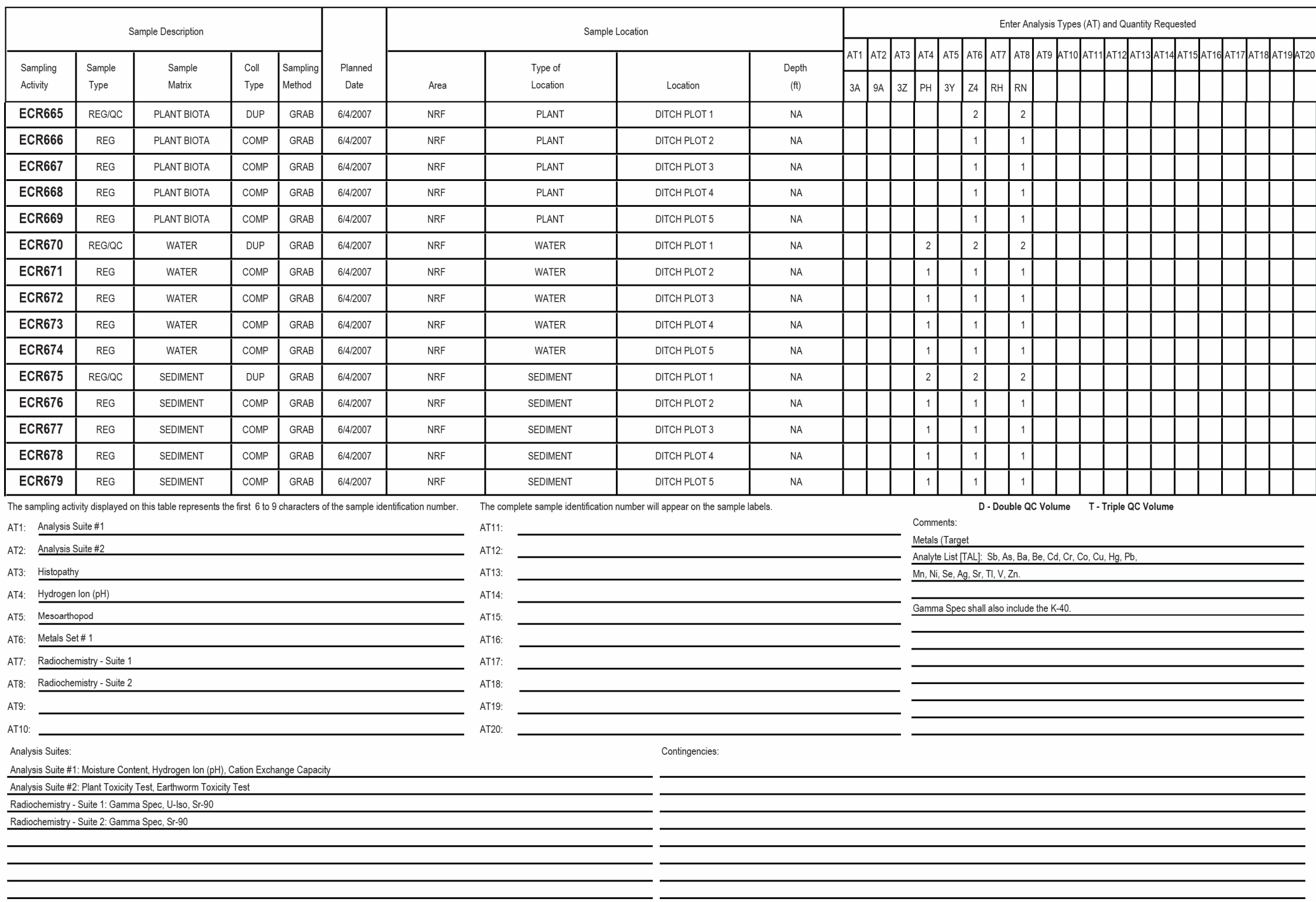


Plan Table Number: $\quad$ LTS ECM 2007

SAP Number: ICPIEXT-06-01130

Sampler. Haney, T.J.

Date: $06 / 1112007 \quad$ Plan Table Revision: $1.0 \quad$ Project. LONG TERM ECOLOGICAL MONITORING FY $2007 \quad$ Project Manager. HANEY, T.J.

SMO Contact CHAMBERS, LS

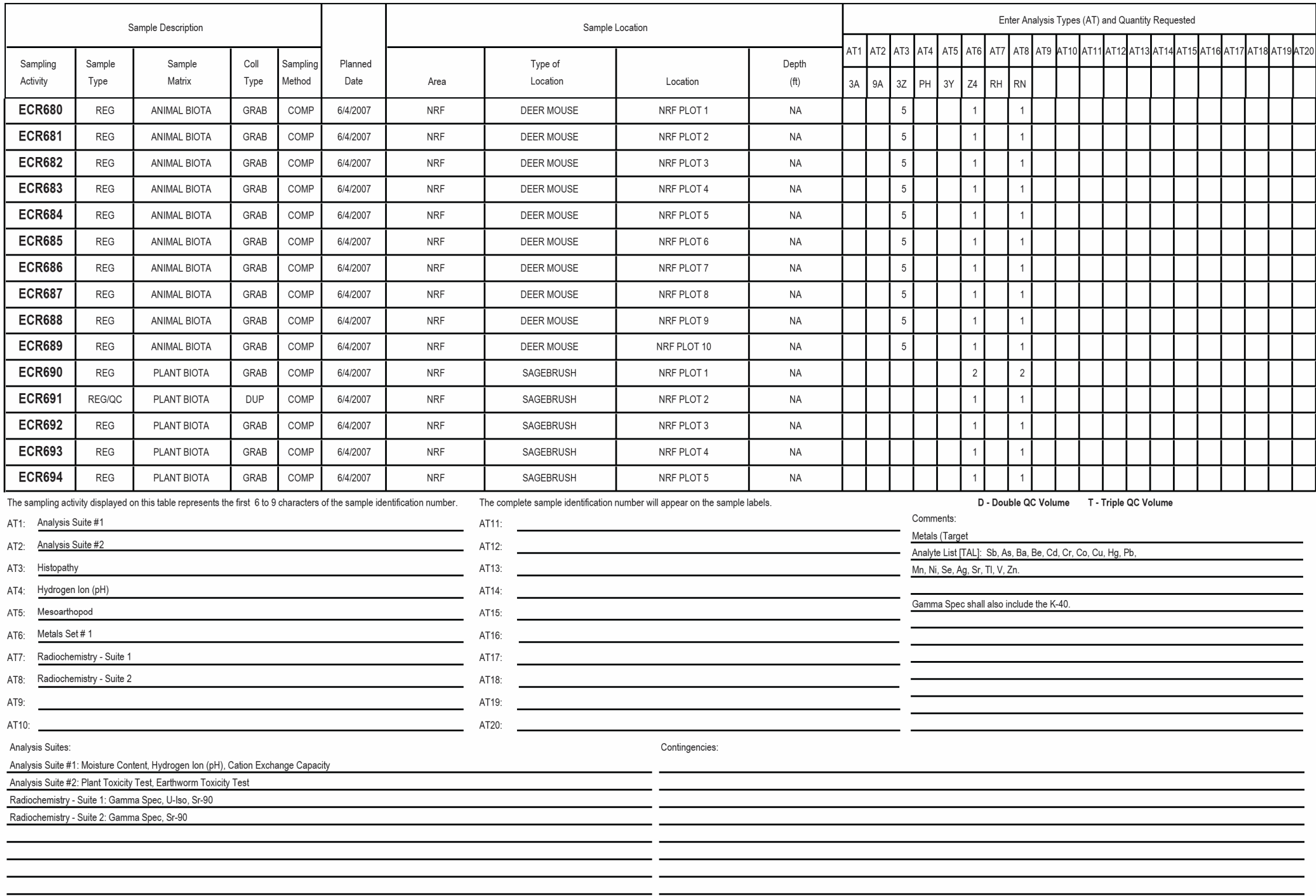


Plan Table Number: LTS_ECM_2007

SAP Number: ICPIEXT-06-01130

Date: $\quad$ 06/11/2007 Plan Table Revision: 1.0 Project. LONG TERM ECOLOGICAL MONITORING FY 2007

Project Manager. HANEY,T.J.

Sampler. Haney, T. J.

SMO Contact: CHAMBERS, L. S.

Enter Analysis Types (AT) and Quantity Requested

\begin{tabular}{|c|c|c|c|c|c|}
\hline \multicolumn{5}{|c|}{ Sample Description } & \multirow[b]{2}{*}{$\begin{array}{l}\text { Planned } \\
\text { Date }\end{array}$} \\
\hline $\begin{array}{l}\text { Sampling } \\
\text { Activity }\end{array}$ & $\begin{array}{l}\text { Sample } \\
\text { Type }\end{array}$ & $\begin{array}{l}\text { Sample } \\
\text { Matrix }\end{array}$ & $\begin{array}{l}\text { Coll } \\
\text { Type }\end{array}$ & \begin{tabular}{|l|} 
Sampling \\
Method
\end{tabular} & \\
\hline ECR695 & REG & PLANT BIOTA & GRAB & COMP & 6/4/2007 \\
\hline ECR696 & REG & PLANT BIOTA & GRAB & СOMP & 6/4/2007 \\
\hline ECR697 & REG & PLANT BIOTA & GRAB & СOMP & 66/4/2007 \\
\hline ECR698 & REG & PLANT BIOTA & GRAB & COMP & 6/4/2007 \\
\hline ECR699 & REG & PLANT BIOTA & GRAB & СOMP & 6/4/2007 \\
\hline ECR700 & REG/QC & PLANT BIOTA & DUP & COMP & 6/4/2007 \\
\hline ECR701 & REG & PLANT BIOTA & GRAB & COMP & 6/4/2007 \\
\hline ECR702 & REG & PLANT BIOTA & GRAB & COMP & 6/41/2007 \\
\hline ECR703 & REG & PLANT BIOTA & GRAB & COMP & 6/4/2007 \\
\hline ECR704 & REG & PLANT BIOTA & GRAB & COMP & 6/4/2007 \\
\hline ECR705 & REG & PLANT BIOTA & GRAB & COMP & 6/4/2007 \\
\hline ECR706 & REG & PLANT BIOTA & GRAB & COMP & 6/4/2007 \\
\hline ECR707 & REG & PLANT BIOTA & GRAB & COMP & 6/4/2007 \\
\hline ECR708 & REG & PLANT BIOTA & GRAB & COMP & 6/4/2007 \\
\hline ECR709 & REG & PLANT BIOTA & GRAB & COMP & 6/4/2007 \\
\hline
\end{tabular}

The sampling activity displayed on this table represents the first 6 to 9 characters of the sample identifoation nofer.

AT1: Analysis Suite \#1

AT2: Analysis Suite \#2

AT3: Histopathy

AT4: Hydrogen lon $(\mathrm{pH})$

AT5: Mesoarthopod

AT6: Metals Set\#1

AT7: Radiochemistry - Suite 1

AT8: Radiochemistry - Suite 2

AT9:

AT10:

Analysis Suites:

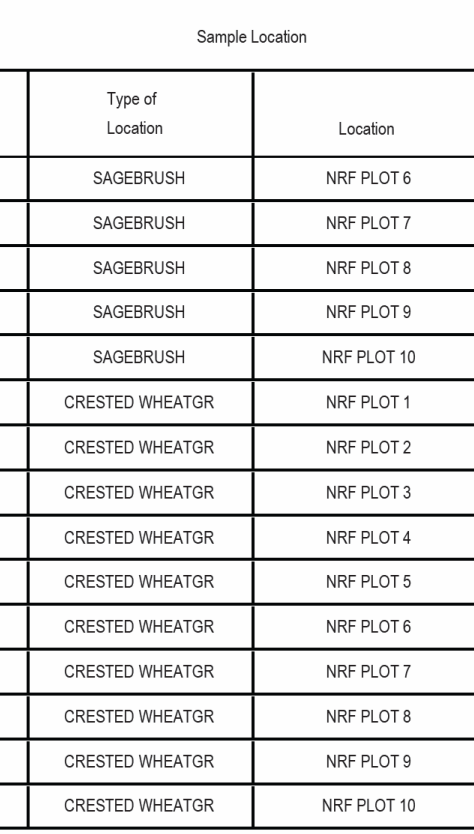

\begin{tabular}{|l|}
\hline \multirow{2}{*}{$\begin{array}{c}\text { Depth } \\
\text { (tt) }\end{array}$} \\
\cline { 2 - 3 }
\end{tabular}

The complete sample identifcation number will appear on the sample labels.

AT11:

AT12:

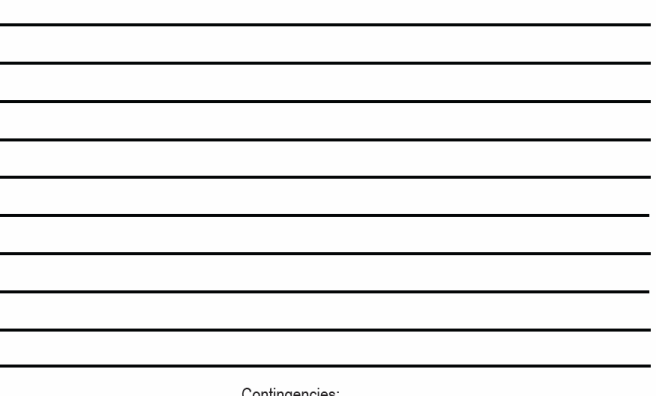

D - Double QC Volume T- Triple QC Volume

Comments:

Analyte List TALl: Sb, As, Ba, Be, Cd, Cr, Co, Cu, Hg. Pb

$\mathrm{Mn}$. Ni. Se, Aq. Sr. TI. V. Zn.

Gamma Spec shall also include the K-40.

Analysis Suite \#1: Moisture Content, Hydrogen lon (PH), Cation Exchange Capacity

Analysis Suite \#2: Plant Toxicity Test Earthworm Toxich T

Radiochemistry- Suite 1: Gamma Spec, U-Iso, Sr-90

Radiochemistry - Suite 2: Gamma Spec, Sr-90

(a) 
Plan Table Number: LTS_ECM_2007

SAP Number: ICPIEXT-06-01130

Sampler: Haney, T. J.

Date: 0611112007 Plan Table Revision: 1.0 Project: LONG TERM ECOLOGICAL MONITORING FY $2007 \quad$ Project Manager: HANEY,T.J.

SMO Contact: CHAMBERS, L.S

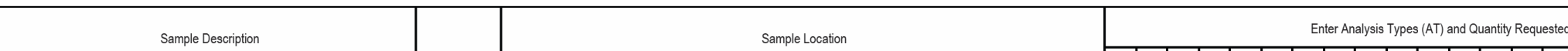

\begin{tabular}{|c|c|c|c|c|c|}
\hline \multicolumn{5}{|c|}{ Descriptio } & \multirow[b]{2}{*}{$\begin{array}{c}\text { Planned } \\
\text { Date }\end{array}$} \\
\hline $\begin{array}{l}\text { Sampling } \\
\text { Activity }\end{array}$ & $\begin{array}{l}\text { Sample } \\
\text { Type }\end{array}$ & $\begin{array}{l}\text { Sample } \\
\text { Matrix }\end{array}$ & $\begin{array}{l}\text { Coll } \\
\text { Type }\end{array}$ & $\begin{array}{l}\text { Sampling } \\
\text { Method }\end{array}$ & \\
\hline ECR710 & REG/QC & SOlL & DUP & сOMP & 6/4/2007 \\
\hline ECR711 & REG & SOlL & GRAB & СOMP & 6/4/2007 \\
\hline ECR712 & REG & SOlL & GRAB & COMP & 6/4/2007 \\
\hline ECR713 & REG & SOIL & GRAB & COMP & 6/4/2007 \\
\hline ECR714 & REG & SOlL & GRAB & сOMP & 6/4/2007 \\
\hline ECR715 & REG & SOIL & GRAB & COMP & 6/4/2007 \\
\hline ECR716 & REG & SOIL & GRAB & COMP & 6/4/2007 \\
\hline ECR717 & REG & SOlL & GRAB & COMP & 6/4/2007 \\
\hline ECR718 & RFG & Soll & GRAB & COMP & 6/1/10007 \\
\hline ECR719 & REG & Soll & GRAB & COMP & 6/4/2007 \\
\hline ECR720 & REG/QC & SOIL & DUP & COMP & 6/4/2007 \\
\hline ECR721 & REG & SOIL & GRAB & COMP & 6/4/2007 \\
\hline ECR722 & REG & Soll & GRAB & COMP & 6/4/2007 \\
\hline ECR723 & REG & SOIL & GRAB & сOMP & 6/4/2007 \\
\hline ECR724 & REG & SOIL & GRAB & COMP & 6/4/2007 \\
\hline
\end{tabular}

The sampling activity displayed on this table represents the first 6 to 9 characters of the sample identification number.

AT1: Analysis Suite\#1

AT2: Analysis Suite \#2

AT3: Histopathy

AT4: Hydrogen lon (PH)

AT5: Mesoarthopod

AT6: Metals Set\# 1

AT7: Radiochemistry - Suite 1

AT8: Radiochemistry - Suite 2

AT:

AT10:

Analysis Suites

\begin{tabular}{|c|c|c|}
\hline $\begin{array}{c}\text { Sample Location } \\
\text { Lype of } \\
\text { Location }\end{array}$ & Location & $\begin{array}{c}\text { Depth } \\
\text { (t) }\end{array}$ \\
\hline SURFACE SOIL & NRF PLOT 1 & $0-0.167$ \\
\hline SURFACE SOIL & NRF PLOT 2 & $0-0.167$ \\
\hline SURFACE SOIL & NRF PLOT 3 & $0-0.167$ \\
\hline SURFACE SOIL & NRF PLOT 4 & $0-0.167$ \\
\hline SURFACE SOIL & NRF PLOT 5 & $0-0.167$ \\
\hline SURFACE SOIL & NRF PLOT 6 & $0-0.167$ \\
\hline SURFACE SOIL & NRF PLOT 7 & $0-0.167$ \\
\hline SURFACE SOIL & NRF PLOT 8 & $0-0.167$ \\
\hline SURFACF SOII & NRF P O OT 9 & $0-0167$ \\
\hline SURFACE SOIL & NRF PLOT 10 & $0-0.167$ \\
\hline SUBSURFACE SOIL & NRF PLOT 1 & $0.167-2$ \\
\hline SUBSURFACE SOIL & NRF PLOT 2 & $0.167-2$ \\
\hline SUBSURFACE SOIL & NRF PLOT 3 & $0.167-2$ \\
\hline SUBSURFACE SOIL & NRF PLOT 4 & $0.167-2$ \\
\hline SUBSURFACE SOIL & NRF PLOT 5 & $0.167-2$ \\
\hline
\end{tabular}

The complete sample identification number will appear on the samplele labels The comp
AT11:

Analysis Suite \#1: Moisture Content, Hydrogen lon (pH), Cation Exchange Capacity

Enter Analysis Types (AT) and Quantity Requested

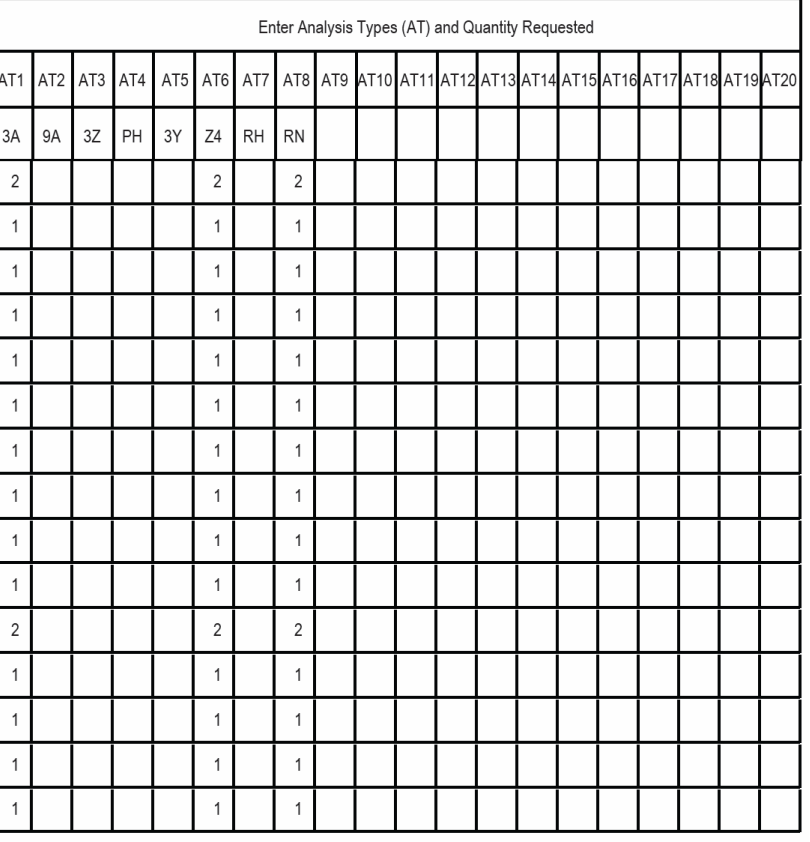

D. Double QC Volume T- Triple QC Volume

Analyte List [TAL]: Sb, As, Ba, Be, Cd, Cr, Co, Cu, Hg, Pb,

\section{$\mathrm{Mn}, \mathrm{Ni}, \mathrm{Se}, \mathrm{Ag}, \mathrm{Sr}, \mathrm{Tl}, \mathrm{V}, \mathrm{Zn}$}

AT13:

T14:

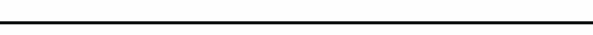

Gamma Spec shall also include the K-40

nalysis Suite \#2: Plant Toxicity Test, Earthworm Toxicity Tes

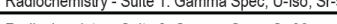

Radiochemistry - Suite 2: Gamma Spec, Sr-90

(2010 
SAP Number: ICPIEXT-06-01130

Sampler. Haney, T. J.
Date: $06 / 112007$
Plan Table Revision: 1.0
Project: LONG TERM ECOLOGICAL MONITORING FY 2007
Project Manager: HANEY, T.J.
SMO Contact: CHAMBERS, L.S

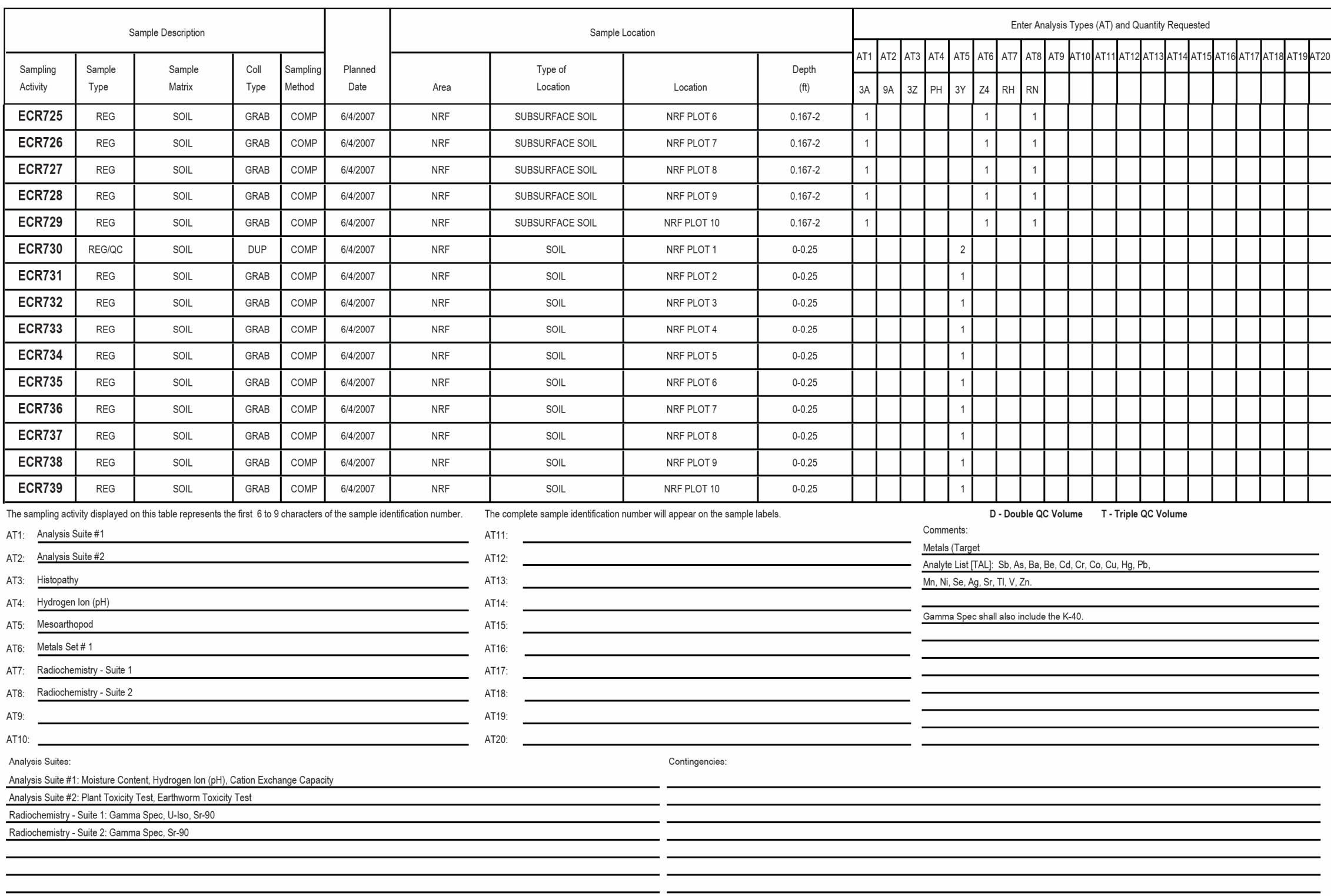


SAP Number: ICPIEXT-06-01130

Date: $06 / 1112007$ Plan Table Revision: 1.0 Project: LONG TERM ECOLOGICAL MONITORING FY 2007 Project Manager. HANEY, T.J.
Sampler: Haney, T. J.

SMO Contact: CHAMBERS, L.S

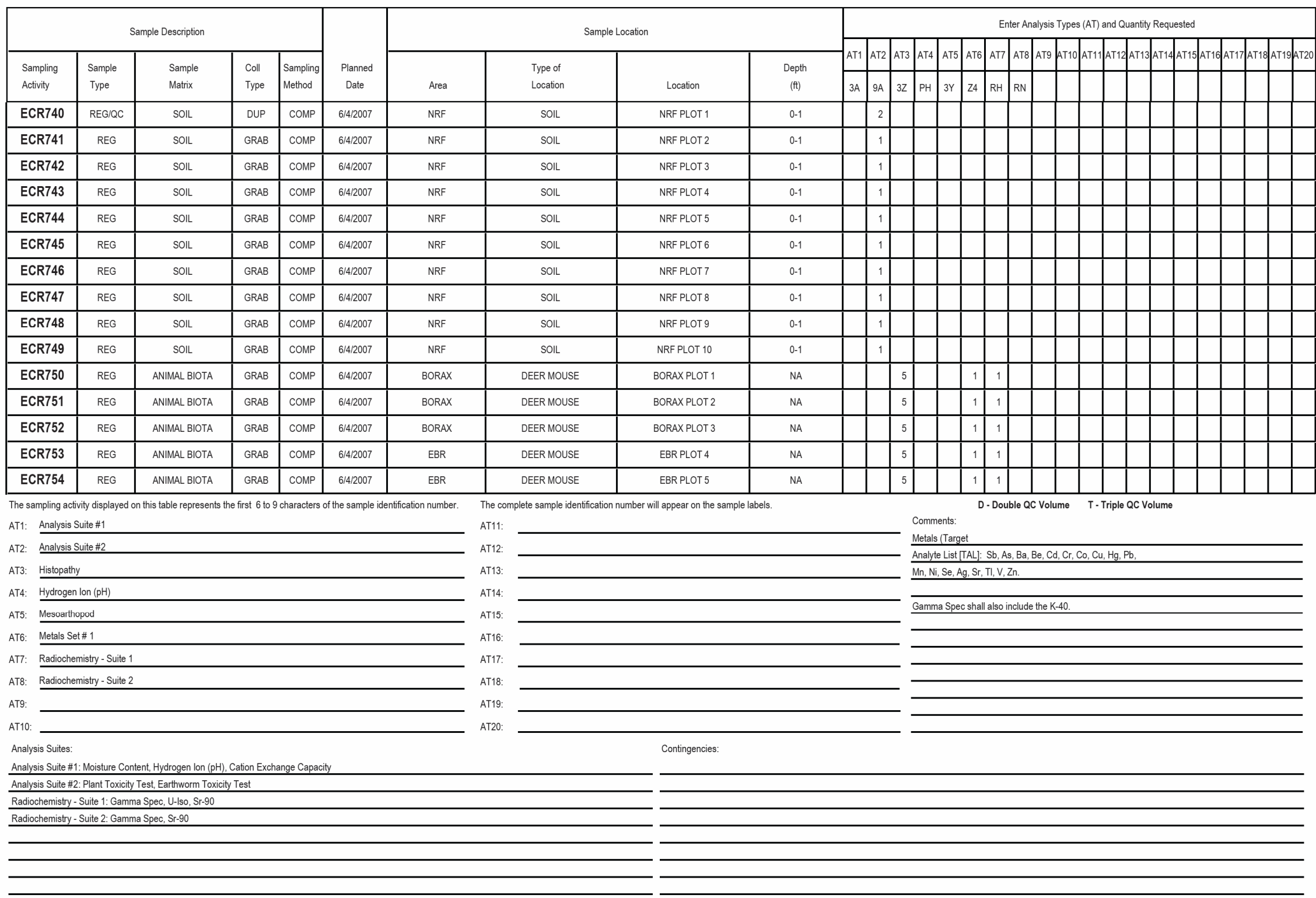


SAP Number: ICPIEXT-06-01130

Sampler: Haney, T. J.
Date: $06 / 11 / 2007$
Plan Table Revision: 1.0
Project: LONG TERM ECOLOGICAL MONITORING FY 2007
Project Manager. HANEY, T.J.
SMO Contact. CHAMBERS, L.S.

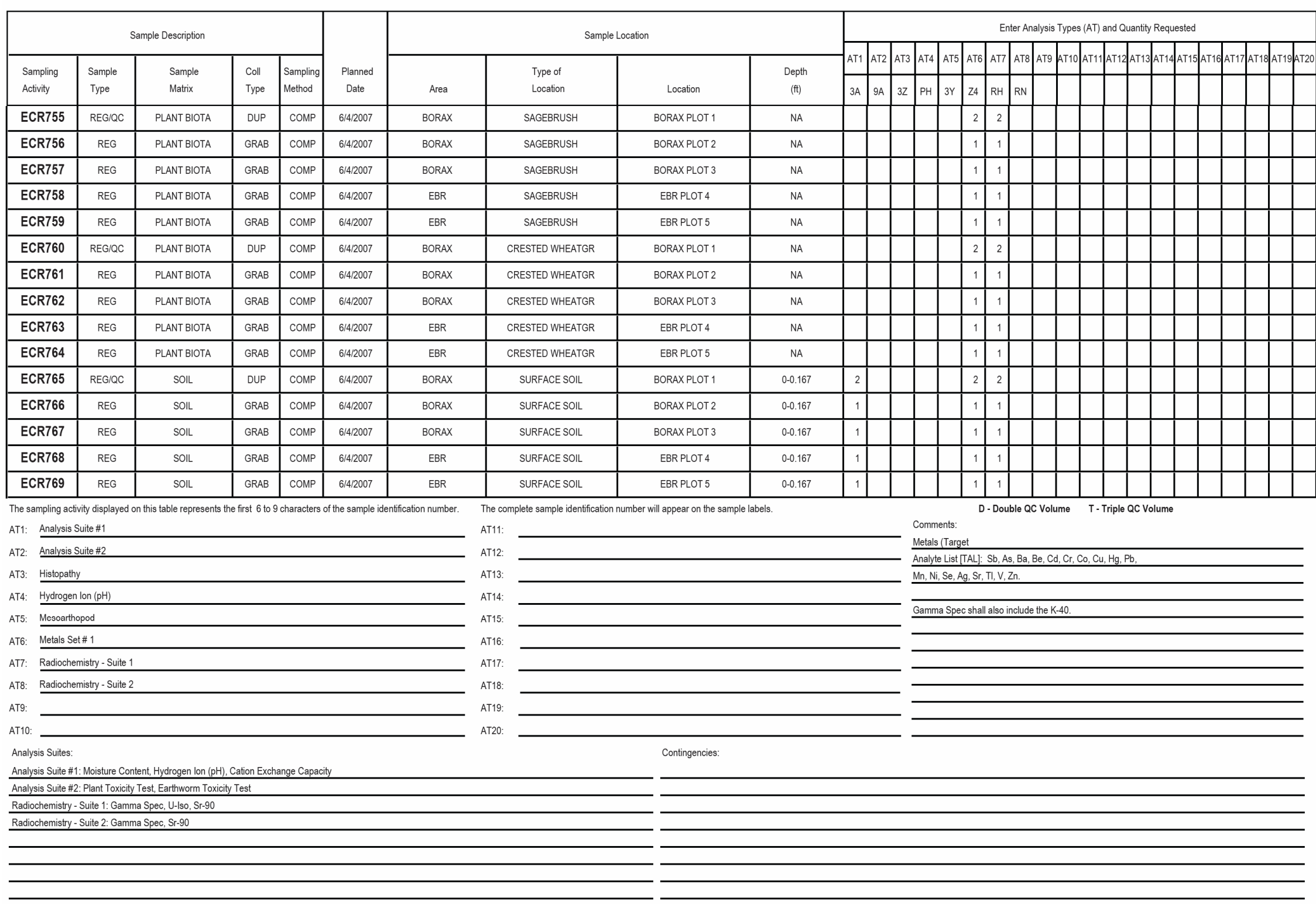


Plan Table Number: LTS_ECM_2007

SAP Number: ICPIEXT-06-01130

Date: $06 / 1112007$ Plan Table Revision: $1.0 \quad$ Project: LONG TERM ECOLOGICAL MONITORING FY 2007
Sampler. Haney, T. J.

SMO Contact: CHAMBERS, L.S.

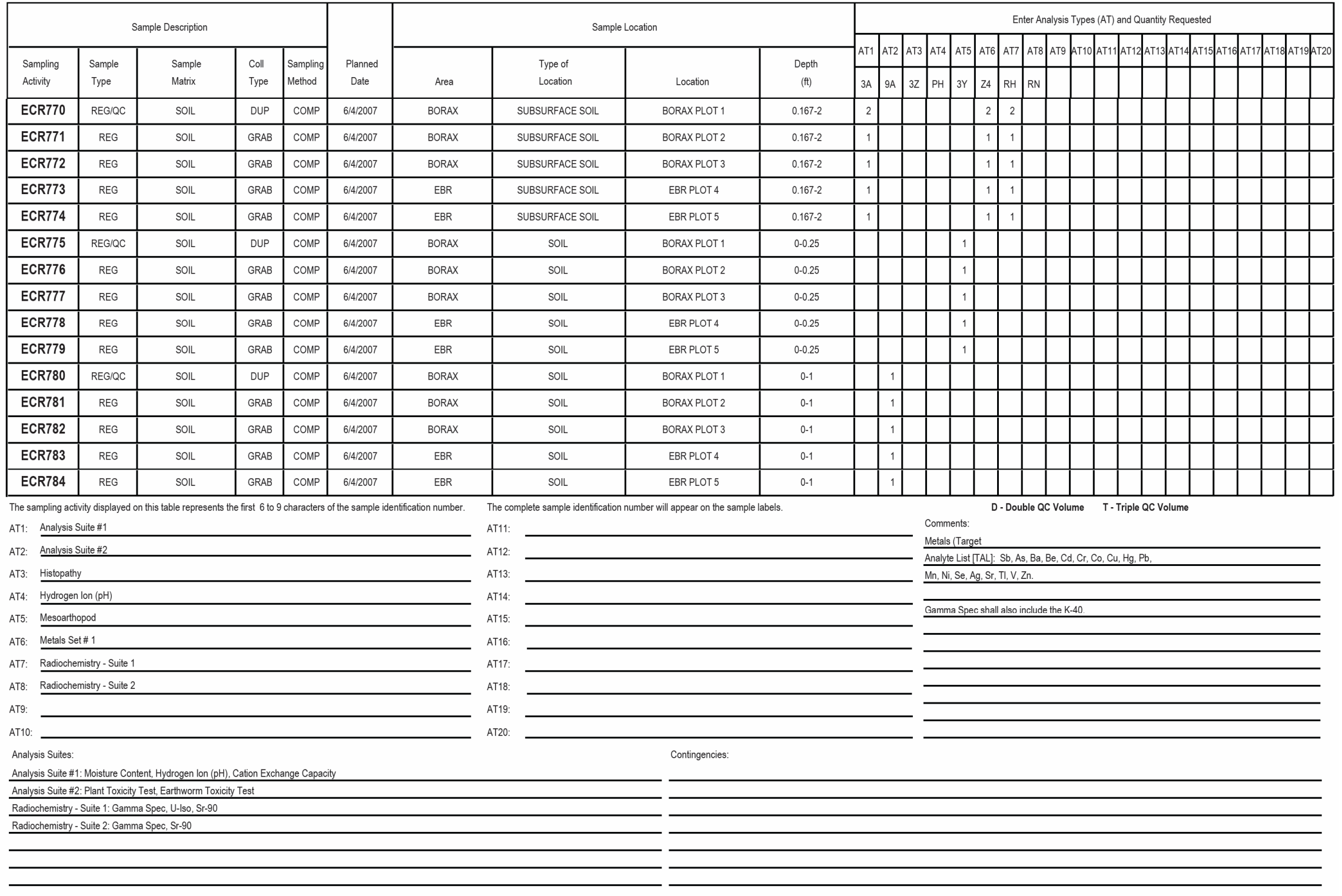


SAP Number: ICPIEXT-06-01130

Date: $06 / 1112007$ Plan Table Revision: $1.0 \quad$ Project: LONG TERM ECOLOGICAL MONITORING FY 2007 Project Manager: HANEY, T.J.
Sampler: Haney, T.J.

SMO Contact. CHAMBERS, L.S

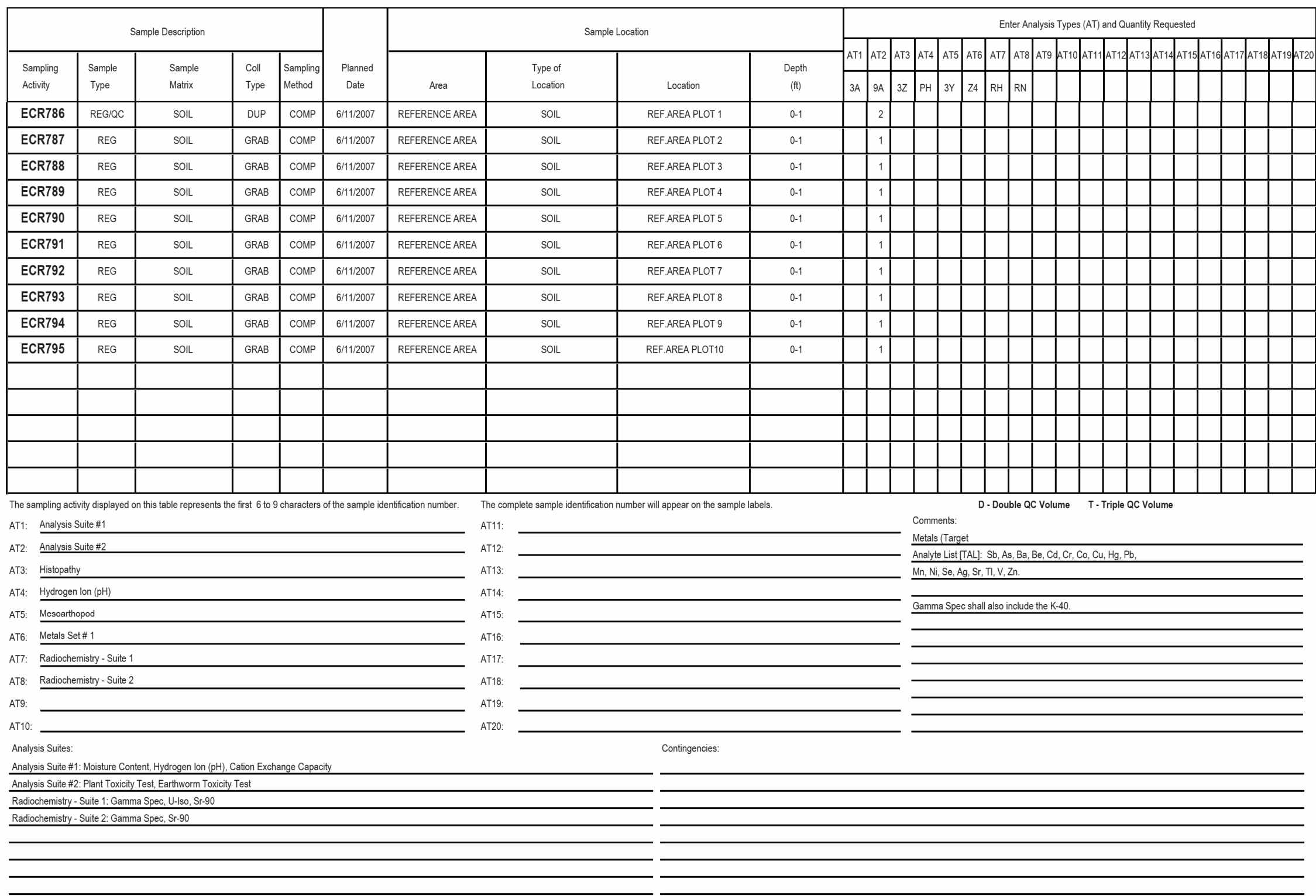


Appendix B

Sample Collection Procedures 
B-2 


\section{Appendix B}

\section{Sample Collection Procedures}

\section{B-1. OVERVIEW}

Sampling for long-term ecological monitoring (LTEM) occurs as presented in the Long-Term Ecological Monitoring Plan for the Idaho National Engineering and Environmental Laboratory (INEEL 2004). Efforts are directed at sampling to determine levels of contamination in the selected media and to detect possible effects. Levels of contamination in soil, deer mice, and plants are determined to validate the Operable Unit (OU) 10-04 ecological risk assessment's assumption of no migration of contamination off the areas of concern (AOCs) and to establish a baseline. Effects data are evaluated for plants, mammals, and avian receptors at the AOCs. This appendix presents the sampling procedures used to collect analytical and effects samples at each AOC:

1. Randomly select plots (generally 10) in the site location grids designated for Fiscal Year (FY) 2007 sampling.

2. Prepare the plots by staking the corners and center and distributing mammal traps in $3-\mathrm{m}(10-\mathrm{ft})$ intervals on the $100 \times 100$-m $(110 \times 110$-yd $)$ plot, as shown in Figure B-1 and discussed in Technical Procedure (TPR) -145, "Biotic and Proximal Soil Sampling."

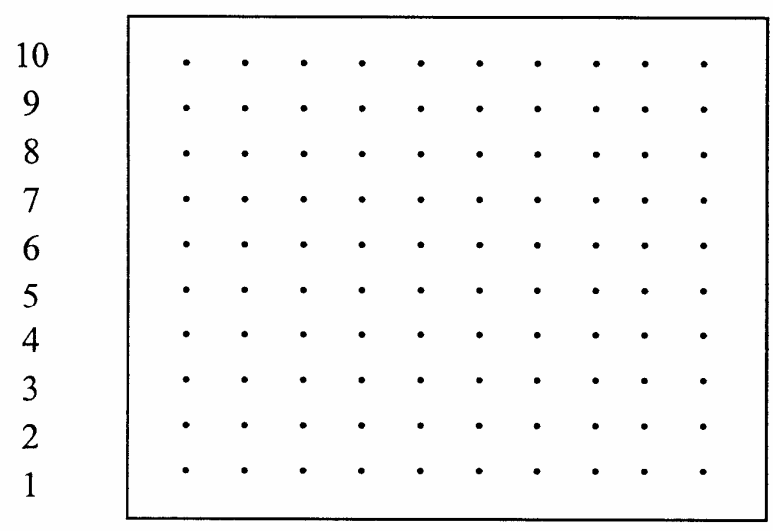
A

Figure B-1. Example of the transect design.

3. Obtain necessary paperwork, including safe work permits, scientific/trapping collection permits, and radiological work permits.

4. Obtain all sampling equipment, forms, and labels (as required).

5. Sample from May to September 2007:

a. Perform soil sampling for plant and earthworm bioassays, analytical concentrations, and soil fauna community structure determination with the Berlese funnel extraction procedure. 
b. Collect plant tissue for analysis.

c. Sample the small mammal community structure, presence/absence, diversity/richness, and density/biomass using the trap and release methodology (the sampling procedure is presented in Section B-3.1.3).

d. Sample the plant community structure, presence/absence, diversity/richness, and density/biomass (the sampling procedure is presented in Section B-3.1.1).

e. Sample bird community structure, presence/absence, diversity/richness, and density/biomass (the sampling procedure is presented in Section B-3.1.2).

f. Sample deer mouse tissue to obtain effects and analytical data (mice should be collected on the last day of community sampling).

g. Harvest small mammals for analytical concentration determination (the sampling procedure is presented in TPR-145).

h. Harvest small mammals for organ-to-body weight measurements, histopathology, and genetic samples (the sampling procedure is presented in Section B-3.4).

6. Decontaminate sampling equipment, the task site, and personnel (as necessary).

7. Prepare samples for storage and shipment to the appropriate facilities:

a. Histopathology specimens will be shipped to the laboratory

b. Preserved invertebrates will be sent to the laboratory

c. Bioassay soils will be shipped to the laboratory for plant and earthworm toxicity bioassays

d. Soil samples will be shipped to the laboratory for chemical and radiological analysis

e. Plant and small mammal samples will be frozen and shipped to the laboratory for chemical and radiological analysis

f. Soil fauna will be extracted and the extract will be shipped to the analysts.

\section{B-2. ANALYTICAL SAMPLING PROCEDURES}

\section{B-2.1 Biota Analytical Samples}

Samples of vegetation, mammals, and soil will be collected for analysis of contaminant concentration.

\section{B-2.1.1 Vegetation Sampling Procedure for Analytical Sampling}

Two types of vegetation (shrubs and grasses), representing the two most common functional plant types at the Idaho National Laboratory (INL) Site, will be collected for chemical analysis. A review of dietary information for herbivorous and omnivorous INL Site wildlife species has resulted in consideration of the following individual plant species and/or types: 
- Wyoming big sagebrush (Artemisia tridentata)

- $\quad$ Crested wheatgrass (Agropyron cristatum) or Indian rice grass (Oryzopsis hymenoides)

- $\quad$ Hardstem bulrush (Scirpus acutus) or other aquatic plant.

Sagebrush is the shrub most commonly used by the INL Site's primary consumers, including the pronghorn, sage grouse, black-tailed jackrabbit, Nuttall's cottontail rabbit, and the pygmy rabbit. In addition, sagebrush is an important component in the diets of avian and mammalian omnivores and herbivorous insects. Wheatgrasses are most widely used and are significant components in the diets of jackrabbits, cottontail rabbits, birds, and small mammals. If crested wheatgrass is unavailable, or the amount is not sufficient, Indian rice grass or other wheatgrasses will be substituted. Hardstem bulrush nutlets are an important waterfowl and shorebird food, while muskrats and geese eat the rhizomes and stems.

Terrestrial vegetation samples will be collected during the early part of the growing season in conjunction with small mammal population analysis and tissue collection. Grass and sagebrush will be sampled in late May or June. A field team member will assess species presence and abundance within each randomly selected $100 \times 100$-m $(110 \times 110$-yd $)$ grid. If wheatgrass or sagebrush is unavailable, the nearest grid that contains a sufficient amount of these species will be evaluated.

Each vegetation tissue sample will be a composite of material from at least five individual plants of the same species. Individual plants should be randomly selected from within each $100 \times 100-\mathrm{m}$ $(110 \times 110$-yd $)$ grid. Plants sampled should be distributed across the plot if possible. Atypical individuals (i.e., individuals resembling less than $5 \%$ of the plants for the area) based on size or herbivory should not be included. If possible, approximately an equal amount of vegetation should be collected from each individual plant.

Clean disposable gloves should be worn. Plant samples should be clipped with pruning shears or grass shears (as appropriate). Plant material from each of the five radial plots should be combined into one plastic bag to make a composite sample. Sagebrush should be clipped on at least two sides and at two different heights to obtain a representative sample.

A minimum weight of fresh biomass required for each analysis is to be provided in the field guidance forms. Sample weight should be verified in the field to ensure that an adequate quantity has been collected. Plant samples should be placed into a sealable plastic bag that has been placed into another sealable plastic bag. Sharp points on woody vegetation should be bent or broken off within the bag to avoid bag puncture. Bags should be labeled, and the field data should be recorded in notebooks or on field data sheets. Samples should be placed in a cooler on ice until frozen or shipped to the laboratory.

Grass samples should be collected by clipping above ground level (e.g., 1.3 to $5.1 \mathrm{~cm}$ [0.5 to $2 \mathrm{in}$.$] )$ with grass shears. Clipping should be adjusted, as needed, to minimize sampling dead vegetation from previous years and to maximize sampling green vegetation from the current growing season. All material above the cutting height will be collected. Dead material should be removed from the sample by hand if unavoidably collected. Grass samples will include new growth of leaves, stems, and any inflorescences present on the plants. It is desirable to remove as much dead material as possible; however, this might be impractical, and an estimate of the percentage of dead material should be noted.

Shrub samples (leaf and stem growth from the current season) should be collected using pruning shears. Shrubs should be clipped at a height between 0.5 and $1.5 \mathrm{~m}(0.55$ and $1.6 \mathrm{yd})$ on at least two sides. It is common to collect woody material during this process. Stripping and keeping fresh leaves and stems from the woody material might be necessary. 
Aquatic plants should be collected along the margins of the wastewater ponds. One composite sample will be collected at each aquatic sample location. The aboveground portion of each plant should be cut and placed in a labeled, heavy-duty plastic bag and then placed in a cooler with ice for transport to the analytical laboratory.

These procedures can be modified in the field, as appropriate, based on the professional judgment of the field team leader (FTL). All modifications will be documented in the field logbook or on the field sampling data sheets. Soil samples collocated with the plant tissue samples (composited from each corner and the center of the $100 \times 100-\mathrm{m}[110 \times 110$-yd $]$ grid) also will be collected.

\section{B-2.1.2 Mammal Sampling Procedure for Analytical Sampling}

The deer mouse (Peromyscus maniculatus), a primary prey item for both secondary and tertiary consumers is commonly used to represent several important linkages in the food chain and is the primary choice for collection because it is omnivorous, widespread, and relatively easy to collect.

Mammal sampling will be performed in accordance with applicable sections of TPR-145 and the following information. Deer mice will be collected for tissue analysis. Typically, it will be necessary to collect several deer mice for each analysis to obtain the $60 \mathrm{~g}$ of tissue required. Deer mice will be composited to obtain the required tissue amounts. Compositing will not include segregation of small mammals by sex or age but will be limited to the single species. Small mammal species - other than deer mice - will be weighed, measured, ear tagged, have other life history or details recorded in the field logbook, and released.

The same trapping design (see Section B-3.1.3) used to evaluate small mammal population/community data will be used to collect deer mouse tissue samples for analytical assessment. Ten trapping locations or sample plots will be used in each grid. Each sample plot will require a 2- to 3 -week trapping period and will consist of 100 traps placed along 10 parallel transect lines (10 traps on each). Each transect will follow a roughly straight line $100 \mathrm{~m}(110 \mathrm{yd})$ long. An example of the transect design is shown in Figure B-1.

At each plot, traps will be opened Monday afternoon and left open (weather permitting) three nights (Monday through Wednesday night), closed four nights (Thursday through Sunday), and then reopened an additional three nights (Monday through Wednesday night). If the weather becomes too hot, it may be necessary to close traps during the day to minimize mortality of diurnal species. Once an animal is trapped, a uniquely numbered ear tag will be attached. The ear tag correlates with the trap location, genus, species, collector's initials, and date recorded in a field logbook. The animal should be emptied into a plastic bag. It should be sexed, aged (adult/juvenile), weighed, and identified to its species if possible. A ruler should be used to measure the head--body length, ear (from skull to tip), tail, and right hind foot to the nearest millimeter. The animal should then be returned for release to the location it was trapped. All information should be recorded on the data sheet.

Deer mice will be collected for chemical and radiological analysis, genetics, and histopathology. On the last day of the population surveys, at least three deer mice in each grid will be retained as a single composite sample. Animals to be harvested for contaminant analysis will be dispatched in the field. After dispatch, each carcass will be weighed and placed in another clean plastic bag. The amount of sample material in the composite sample will be determined by summing the weights of the individual specimens from each location. Processing should take place as soon as possible after checking traps to reduce potential degradation of the specimen. Samples will be placed on ice for transport to the processing center. 
Portions of each animal's liver and kidney will be collected for weight and histopathology. A ventral incision will be made with a clean scalpel blade. The liver and kidney will be removed and weighed to the nearest $0.01 \mathrm{~g}$. Small sections of the liver and kidney will be sliced and placed in a $10 \%$ buffered formalin. This solution is potentially carcinogenic and should be handled with caution, as detailed on the respective material safety data sheets. The jar will be labeled with appropriate sample information (i.e., time, date, and sample identification number). Small sections of maternal and fetal tissue will be removed from female mice. The carcasses will be placed in a sealable plastic bag and placed inside another bag with the sample labeled. Chain-of-custody forms will be completed.

Tissue samples for residue analysis should be frozen and shipped on Blue Ice ${ }^{\mathrm{TM}}$ (or equivalent) to the laboratory. Dry ice can cause serious skin burns if handled incorrectly. Gloves should be worn when handling dry ice.

A single voucher specimen will be photographed but will not be analyzed for contaminants. An experienced wildlife biologist will examine the voucher specimen to verify genus and species.

\section{B-2.2 Soil Analytical Characterization}

Soil samples will be collected from the surface 0 to $5 \mathrm{~cm}(0$ to 2 in.) and subsurface 5 to $61 \mathrm{~cm}$ ( 2 to 24 in.) or bedrock (i.e., limited to two sampling intervals) and will consist of composites from locations within the sampling plot designs that correspond to plants from which vegetation samples are collected.

Before sampling, it is important to calculate the total volume of sample material that will be needed from each increment sample location to ensure that the volume required for each analysis is available to completely fill each sample container. The analysis-specific volumes are specified in the Appendix A field guidance forms. Sampling locations specified will be identified and marked using surveying stakes, lath, or flags. The soil will be evaluated for contamination concentrations.

\section{B-2.2.1 Surface Soil Material}

Composite surface material samples will comprise five increment subsamples collected from each of the corners and center point of a 100-m (110-yd) square. All or a portion of the increment samples will be mixed together to create a composite sample representative of average constituent concentrations within the area to be investigated. For a given composite sample, the volume of each increment sample must be the same and must equal $1 / \mathrm{n}$ of the required composite sample volume, where $\mathrm{n}$ equals the number of increment samples making up the composite sample.

Surface material samples will be collected as follows:

1. At each subsample location, an area approximately $61 \mathrm{~cm}(24 \mathrm{in}$.) in diameter is cleared of surface vegetation, nondecomposed plant litter, and debris.

2. A decontaminated stainless-steel spoon or hand auger is used to collect surface material to a depth of $5 \mathrm{~cm}$ ( 2 in.). A stainless-steel pick can be used as needed to loosen the soil. To the extent possible, gravel-size or larger particles and debris are eliminated, based on visual observation.

3. The material is described visually, and observations are recorded on the soil sample field data sheet. 
4. The increment sample is sieved through a No. 10 mesh if rocks are present and the fine fraction is placed into a decontaminated stainless-steel mixing bowl and then thoroughly mixed.

5. For composite samples, Steps 1 through 4 are repeated at each increment sample location for that composite sample, adding each successive increment sample to the mixing bowl.

6. The sample material is mixed in the stainless-steel bowl using a decontaminated stainless-steel spoon, and then placed into the appropriate laboratory-supplied sample containers.

7. The containers are labeled and handled as required. Soil subsample location descriptions and collection information will be documented in the logbook in accordance with Management Control Procedure (MCP) -1194, "Logbook Practices for ICP CERCLA and Removal Action Projects.”

\section{B-2.2.2 Subsurface Soil Material}

Subsurface material samples will be collected as composite samples. Before sampling, it is important to calculate the total volume of collected sample material at each increment sample location to ensure that the volume required for each analysis is available to completely fill each sample container. The analysis-specific volumes are specified in the Appendix A field guidance forms. Specified sampling locations will be identified and marked using surveying stakes, lath, or flags.

Composite surface material samples will comprise five increment subsamples collected from each of the corners and center point of a 100-m (110-yd) square. All or a portion of the increment samples will be mixed together to create a composite sample representative of average constituent concentrations within the area to be investigated. For a given composite sample, the volume of each increment sample must be the same and must equal $1 / \mathrm{n}$ of the required composite sample volume, where $\mathrm{n}$ equals the number of increment samples making up the composite sample.

Subsurface material samples are collected as follows:

1. At each sample location, clear an area approximately $61 \mathrm{~cm}(24 \mathrm{in}$.) in diameter of surface vegetation (nondecomposed plant litter) and debris.

2. Use a decontaminated stainless-steel spoon or hand auger to collect subsurface material from a depth of $5 \mathrm{~cm}(2 \mathrm{in}$.) to no more than $61 \mathrm{~cm}(24 \mathrm{in}$.) below ground surface. A stainless-steel pick can be used as needed to loosen the soil. To the extent possible, remove gravel-size or larger particles and debris. Record the depth for each soil core collected.

3. Record observations on the soil sample field data sheet.

4. Sieve the soil through a No. 10 mesh (if gravel or rocks are present) into a decontaminated stainless-steel mixing bowl and then mix.

5. For composite samples, repeat Steps 1 through 4 at each subsample location, adding each successive increment sample to the mixing bowl.

6. Mix the soil in a stainless-steel bowl using a decontaminated stainless-steel spoon and then place it in the appropriate laboratory-supplied sample containers.

7. Label and handle the containers as required and document the soil subsample location descriptions and collection information in the logbook in accordance with MCP-1194.

8. Collect GPS information from the center of each sample grid location. 


\section{B-2.3 Soil Nutrient and Physical Characterization}

Soil samples for soil nutrient and physical characterization will be collected at the same locations as soil samples for contaminant analysis. Each composite sample will be collected as follows:

- $\quad$ Soil sampling sites will be collocated with chemical and radiological soil samples.

- After collection of the chemical analysis samples (described above), appropriate amounts of homogenized soil will be placed into the shipping containers for analysis. Approximately $500 \mathrm{~g}$ will be placed into a sealable plastic bag for soil nutrient and physical characterization.

- $\quad$ The containers will be labeled and handled as specified in the field sampling plan (FSP).

These procedures can be modified in the field, as appropriate, based on the professional judgment of the FTL. All modifications will be documented in the field logbook or on the field sampling data sheets.

\section{B-3. EFFECTS SAMPLING B-3.1 Population/Community Data}

Ecological populations or communities are usually large and complex. These systems must be described and quantified to compare them with one another or assess changes in them. Several ecological variables can be measured (e.g., density, frequency, coverage, and biomass) to describe populations and communities. These measurements are used to characterize aspects of populations and communities such as presence/absence, population density, population distribution, species diversity, and productivity (biomass).

\section{B-3.1.1 Vegetation}

Fifty Daubenmire quadrats will be collected at each of the 10 AOC plots. Transects will be located between each of the 10 trapping lines (see Figure B-1) in each $100 \times 100$-m plots. Each transect line will have five quadrat locations spaced approximately $2 \mathrm{~m}(6 \mathrm{ft})$ apart. These locations will be selected by striding 20 to 25 paces between quadrats starting at the edge of the $100 \times 100-\mathrm{m}$ plot. The quadrat frame will be placed with the left side of the short end of the frame at the edge of the right foot. A $1 \times 3-\mathrm{m}$ $(1.1 \times 3.3-y d)$ quadrat will be used to estimate percent ground cover. As the quadrat frame is placed along the tape at the specified intervals, the canopy coverage of each plant species will be estimated. In addition, the data will be recorded by quadrat, species, and cover class. Canopy coverage can be estimated, as follows, for both perennial and annual plant species:

1. The quadrat frame is observed directly from above, and the cover class for all individuals of a plant species in the quadrat is estimated as a unit. All other kinds of plants are ignored, as each plant species is considered separately.

2. A line drawn about the leaf tips of the undisturbed canopies (ignoring inflorescence) is imagined, and these polygonal images are projected onto the ground. This projection is considered "canopy coverage." The classes that the canopy coverage of the species falls into can be determined (see Table B-1).

3. Canopies extending over the quadrat are estimated even if the plants are not rooted in the quadrat. 
4. The data are collected during a period of maximum growth for key species.

5. For tiny annuals, it is helpful to estimate the number of individuals that would be required to fill $5 \%$ of the frame. A quick estimate of individuals in each frame will then provide an estimate as to whether the aggregate coverage falls in Class 1 or 2, etc.

6. Overlapping canopy cover is included in the cover estimates by species; therefore, total cover might exceed $100 \%$. Total cover might not reflect actual ground cover.

Table B-1. Plant cover classes.

\begin{tabular}{ccc}
\hline Coverage Class & $\begin{array}{c}\text { Range of Coverage } \\
(\%)\end{array}$ & $\begin{array}{c}\text { Midpoint of Range } \\
(\%)\end{array}$ \\
\hline 1 & 0 to 5 & 2.5 \\
2 & 6 to 25 & 15.0 \\
3 & 26 to 50 & 37.5 \\
4 & 51 to 75 & 62.5 \\
5 & 76 to 95 & 85.0 \\
6 & 95 to 100 & 97.5 \\
\hline
\end{tabular}

While using this method, it is important to keep track of the growth form of each species so that comparisons of grass vs. forb vs. shrub can be made. In addition, an estimation of the cover of bare ground and rocks will provide additional characterization data. While conducting this survey, it is important to remember to record total cover for each quadrat, because this might differ from the sum of the cover values for individual species (due to plant canopy overlap). The surveyor should have a cover category for each quadrat among all identifiable species, mosses (if any), bare ground, rocks, and total cover.

Within each quadrat, the shrub height will be measured by species. To measure shrub height, one person will hold a telescoping rod or other measurement device in the center of a shrub while the other person records the height. If no shrub is present within the plot, the closest shrub(s) to the quadrat of each of the dominant species will be measured.

Once the surveys are complete, the species cover can be estimated by multiplying the number of times a class is recorded by the midpoint of that cover class, adding the results for each class, and calculating an average by dividing by the total number of quadrats sampled. Data are usually collected from many quadrats located along a transect, so that the transect is the sample unit. Therefore, data must be collected from several transects to determine the sample's precision for statistical analysis of cover data.

This method recognizes the difficulty in accurately assigning an exact percent cover value to each quadrat, because even highly experienced workers are unlikely to visually estimate closer than approximately 5\% cover. Assigning broad cover classes provides an equally accurate result as long as the data follow a normal distribution around the midpoint within each class. The narrower upper and lower classes of the Daubenmire scale protect against skewed data in extremely sparse or dense vegetation. 
Ranking the data into broad classes is also a relatively rapid procedure because observers are not required to spend as much time contemplating quadrat cover to the nearest percent. In fact, rapid evaluation of each quadrat is the key to success with this approach, since a large sample is less sensitive to the occasional incorrect ranking.

\section{B-3.1.2 Avian}

The avian wildlife on designated study areas at the INL Site will be monitored with point counts and nest searches. Avian point counts will be conducted to assess species occurrence and relative abundance in each study area. Point counts have been used throughout North America for long-term bird monitoring programs such as the Breeding Bird Survey (BBS). The BBS is a roadside route survey of avifauna designed to monitor abundance and distribution of birds in both the U.S. and southern Canada. It began in the eastern U.S. in 1966 but is now nationwide in scope (Bystrak 1981; Robbins, Bystrak, and Geissler 1986). Since 1985, official BBS and modified "mini-routes" have been surveyed at the INL Site (Belthoff and Ellsworth 1999). Nest searches will be used to evaluate the feasibility of harvesting eggs for toxicology research.

Each area of concern (i.e., each waste area group [WAG]) will be divided into 10 randomly chosen $100 \mathrm{~m}^{2}$ plots according to the small mammal trapping protocol. These plots will be used as a reference for designing walking or driving routes through each area. Routes will be designed to survey an area similar to that covered by the mammal plots, and points will be located near or in the plots as often as possible. Points will be located at least $400 \mathrm{~m}$ from the nearest neighboring point. Each point will be named, flagged, and marked using a GPS unit. Each route consists of 10-point count locations. The route for the reference area was established in 2004 and will remain the same in subsequent years.

Breeding Bird Surveys are conducted during the peak of the nesting season, primarily in June, although surveys in desert regions and some southern states (where the breeding season begins earlier), are conducted in May (USGS 2006). Similar to the surveys already established on the INL, the LTEM project surveys will be conducted from mid June to early July. Surveys will be performed only when weather conditions are satisfactory as prescribed by the BBS protocol. Temperature, wind speed, and cloud cover at the start and end of each survey will be recorded in an entry form as presented in Attachment 1.

Each point along a route will be the site of one 3-minute, unlimited radius point count. At each point an observer will count all the individuals seen or heard within the allotted time period. Counting the same individual twice should be avoided even if encountered at different count locations. Surveys begin approximately one-half hour before sunrise and continue until three replicates are completed, with at least 45 minutes elapsing between the start of one replicate and the start of the next. This pattern avoids potential bias that disturbance may cause in subsequent replicates. Surveys will not be conducted during inclement weather, which includes any amount of precipitation, wind exceeding $12 \mathrm{mph}$, or other conditions that interfere with detecting birds by sight or sound.

Nest searches also will be conducted within the designated mammal plots. Surveyors will systematically walk through each grid with drag lines, or by visual inspection, and flag the location of any nests that were found and record the species and other pertinent information about the nest site. Nests will be digitally photographed. 


\section{B-3.1.3 Small Mammals}

Small mammals will be evaluated by using live trapping methods. The 10 sample plots established for biota and soil analytical sampling will be used to assess the small mammal population/community data in the sampling area. Each sample plot will require a 2- to 3-week trapping period and will consist of 100 traps placed along 10 transect lines (10 traps on each) in a line grid formation. Each of the transects will approximately follow a 100-m-long (110-yd-long) straight line. An example of the transect design is shown in Figure B-1.

Traps will be left open for three nights, closed four nights, and then reopened an additional three nights. Once an animal is trapped, a uniquely numbered ear tag will be attached. The ear tag will correlate with the trap location, genus, species, collector's initials, and date recorded in a field logbook. The animal should be emptied into a plastic bag. It should be sexed, aged (adult/juvenile), weighed, and identified to its species if possible. A ruler should be used to measure the head-body length, ear (from skull to tip), tail, and right hind foot to the nearest millimeter. The animal should then be released to the original location from where it was trapped. All information should be recorded on the data sheet.

The mark-and-recapture method will be used in estimating population densities. This method involves several steps:

1. Trapping and marking some individuals of a population

2. Releasing the known number of marked individuals back into the population from which they were captured

3. Trapping some individuals of the population after the marked individuals have had a chance to redistribute themselves into the population

4. Estimating the total population size by a series of computations that are based on the ratio of marked to unmarked individuals in the recapture attempt.

Generally speaking, if the population is large, the marked individuals will become diluted within the population and only a few of the marked individuals would be expected to appear in the second sample. If assumptions about the sampling and animals' distribution are correct, then the proportion of marked individuals in the second sample would be the same as the entire population.

Like all estimation procedures, a number of assumptions must be met to validly use this method:

- $\quad$ The two samples taken from the population must be random samples (i.e., all individuals in the population have an equal and independent chance of being captured during the time of sampling)

- There is no change in the ratio of marked to unmarked animals, meaning that from initial capture to recapture, there must be no significant addition of unmarked animals to the population through births or immigration

- $\quad$ The population losses from mortality and emigration must remove the same proportion of marked and unmarked individuals

- $\quad$ The marking of individuals does not affect their mortality

- Individuals do not lose marks. 
The Peterson-Lincoln Index, the simplest method for determining the population size, will be used. The total population can be estimated as follows:

- $\quad$ Assume the total estimated population size contains $\mathrm{N}$ individuals

- $\quad$ Sample M individuals from this population, mark these animals, and return them to the population

- Sample a second set of $\mathrm{n}$ individuals from the population; this sample contains recaptured animals (i.e., individuals captured and marked in the first sampling).

Estimate the population size, N, by the following equation.

$N=M n / R$

Equation (B-1) might overestimate the population size (i.e., it is biased) when samples are relatively small. Nc is a nearly unbiased estimate of population size if the number of recaptured animals, $\mathrm{R}$, is at least eight. Using Equation (B-2) can reduce this bias:

$$
N c=\frac{(M+1)(n+1)-1}{R+1}
$$

The approximate variance, $\mathrm{s}^{2}$, of this estimate is in Equation (B-3) below:

$$
s^{2}=\frac{(M+1)(n+1)(M-R)(n-R)}{(R+1)^{2}(R+2)}
$$

With the standard deviation, s, $95 \%$ and $99 \%$ confidence limits on the population estimate are given by Equations (B-4) and (B-5) below:

$\mathrm{N}($ or $\mathrm{Nc})+1.96(\mathrm{~s})(95 \%$ confidence limits $)$

and

$\mathrm{N}($ or $\mathrm{Nc})+2.58(\mathrm{~s})(99 \%$ confidence limits $)$.

\section{B-3.1.4 Reptiles}

Several methods were evaluated in 2005 to determine which method or combination of methods was best for monitoring sagebrush and horned lizards. Pitfalls and track plates were unreliable. Active searching along with capture, mark, and release proved to be a good option for studying reptile populations. However, except for the short horned lizards, the subject reptiles generally move very quickly, making it difficult for humans to reliably catch them when temperatures are warm.

Thus, in 2007 at each plot, team members will watch for and record reptile activity while checking small mammal traps. If possible, when checking the traps, technicians should walk facing north or south because it is easier to detect lizards if the sun is to the right or left of the person. When a reptile is observed, the recorders will write down the plot number, the time each plot is surveyed, the air temperature, and the species. Additionally, surrounding habitat and weather (cloud cover) will be recorded. 
B-3.1.4.1 Observational Study, Transects, and Track-Plates. At each plot, each team member will watch for and record reptile activity while checking traps during the morning and afternoon. If possible, when checking the traps, technicians should walk facing north or south because it is easier to detect lizards if the sun is to the right or left of the person.

In the morning, when a reptile is observed, the recorders will write down the plot number, the time each plot is surveyed, the air temperature, and what species were seen. Also, surrounding habitat and weather (cloud cover) will be recorded.

On the last day of the first week of small mammal trapping, sheets of aluminum or other types of material to provide an attractive microhabitat will be located across a selected number of plots at even intervals (depending on ability to place a sheet). Ten sheets of approximately $3 \times 3 \mathrm{ft}$ will be used.

At these plots, tracking plates and possibly scent stations will be used for animal and reptile detection by luring them to a scent and recording their footprints in a tracking medium. Scent stations consist of $1 \times 1-\mathrm{m}$ aluminum plates, heavily smoked with flame, as the tracking surface (Barrett 1983). The scent station attractant, cat food, or predator survey discs will be placed in a slightly elevated position at the center of the station. Stations will be checked for visitation early each morning and tracks will be cleared when necessary. Tracks can be lifted from the plates by lightly pressing with a wide piece of transparent tape. Track outlines will be identified and placed in notebooks for future reference. Track plates should be cleaned and the tracking medium replaced when rain, heat, or signs disturb the carboncoated surface.

B-3.1.4.2 Intensive and Systematic Searching. Intensive and systematic searching will be performed on a selected number of plots at each area of concern. The plots selected will be based on the observational data collected during the mammal trapping.

If captured, collection data recorded (see Attachment A) includes: sex, weight (g), snout-vent length (mm), and tail length ( $\mathrm{mm})$. A unique number will be written with permanent marker on the ventral surface to identify the individual. Painting the side or leg with a noticeable color of fingernail polish changing day-to-day also may be used to help identify an already-captured animal without recapturing. If not captured, the species and location will be noted.

Note the following when performing intensive searching of terrestrial plots:

- The use of gardening gloves is recommended to avoid bites from ants and other invertebrates.

- When sampling areas that are known habitats of venomous snakes, care should be taken to avoid being bitten. Hand-held rakes or small sticks can be used to search the leaf litter and when turning logs and rocks. Always turn the log or rock toward you, so that if an aggressive snake is present, your feet are somewhat protected by the log or the rock.

\section{B-3.2 Earthworm and Plant Bioassay Soil Samples} follows:

Bioassay soil samples will be collected at each plot. Each composite sample will be collected as

- Soil will be taken evenly from 0 to $30 \mathrm{~cm}$. A composite sample of 4 gal will be collected from five locations at each plot. The five locations will be from the center and four corners of the plot. 
- $\quad$ Containers will be labeled with the date, location, and other appropriate information and shipped on ice to the bioassay laboratory for processing.

These procedures can be modified in the field, as appropriate, based on the professional judgment of the FTL. All modifications will be documented in the field logbook or on the field sampling data sheets.

\section{B-3.3 Soil Fauna}

\section{B-3.3.1 The Animals to be Enumerated}

Microarthropods comprise two soil fauna groups: (1) Collembola, also known as springtails, and (2) Acari, also known as mites. The microarthropods are typically the most abundant soil animals in surface layers, especially in association with litter inputs from plants. The size range for microarthropods is $0.1-2.0 \mathrm{~mm}$. Many of these animals are fungus feeders, but many also prey upon each other and on nematodes and flies' eggs. There is a great diversity of species of microarthropods in soil, and considerable time is needed to identify each specimen to species. The approach taken is usually to divide the animals into major subdivision groups within the Collembola and Acari for counting purposes. The animals occur in the field densities in the range 1,000-50,000 per $\mathrm{m}^{2}$, although the lower part of this range is expected for dry environments.

\section{B-3.3.2 Collection of Field Samples}

Samples are to be collected as undisturbed soil discs. One sample will be taken from each plot at each area of concern. Each plastic disc circular is $77 \mathrm{~mm}$ in internal diameter and $88 \mathrm{~mm}$ in external diameter, has a 4-mm depth, and a 45-degree bevel on one outside edge to permit entry into the soil. Each disc is driven flush into the soil using a hammer and wooden board placed above. The disc is then removed intact with litter using a hand trowel and placed upright on a flat surface for immediate transportation to the laboratory.

\section{B-3.3.3 Extraction of Fauna from Field Samples}

The fauna are subjected to an active extraction for removal from soil. The active extraction can be summarized as applying heat and light above the sample so that the animals walk out the bottom of the disc, where they are collected. The active extraction takes 3-7 days to complete, but it has the advantage of recovering the animals in good condition and mostly free of soil and other debris. Physical separation of animals from field samples by use of high-density fluids is not preferred because animals are typically recovered in poor condition. Full details of available extraction methods are given in "Soil Invertebrates" (Coleman et al. 1999) and Standard Soil Methods for Long-Term Ecological Research (Robertson et al. 1999).

Discs returned to the laboratory will be moistened by adding $20 \mathrm{ml}$ water to the surface using a pipette and placed upper surface down into extraction units established in the laboratory. Twelve extraction units can run in the laboratory simultaneously so that three field collections will be processed in separate extraction runs to make 36 samples in all. Each extraction unit has a fiberglass screen nylon mesh supported on a coarse wire grid above a funnel that collects to a plastic vial. A screw-fit lid with an upper airway covers the disc sample to delay moisture loss. A single light with a 60 -watt bulb is placed immediately above each disc for up to 7 days, and the fauna are collected in 1-cm depth of $70 \%$ ethanol in

b. Procedure of the laboratory of Dr. Terence McGonigle (Brandon University, Manitoba, Canada) for the determination of soil fauna of microarthropods in a field sample of surface soil with plant litter. 
the vial. Each vial is checked and emptied daily until fauna no longer appear. The total fauna extracted for a given disc is then pooled and stored in $70 \%$ ethanol.

\section{B-3.3.4 Sorting and Enumeration of Extracted Fauna}

All subsequent laboratory work will involve use of the stereoscopic microscope in the laboratory by a knowable expert in this field. Each sample is sorted, using a Pasteur pipette, into major groups within the Collembola and Acari, and the number of animals for each group will be counted. The sorted samples are stored in $70 \%$ ethanol in separate glass vials, one for each major group for a disc. The major groups recovered are expected to be as shown in Table B-2.

Table B-2. Major groups expected.

\begin{tabular}{ll}
\hline \multicolumn{1}{c}{ Collembola $^{\mathrm{a}}$} & \multicolumn{1}{c}{ Acari } \\
\hline (All are fungivores) & Mesostigmata (predatory) \\
Podurids & Oribatids adult (fungivores) \\
Entomobryids & Oribatids juvenile (fungivores) \\
Neelids & Astigmata (fungivores) \\
Symphyla & Prostigmata (most are fungivores, predators can be separated) \\
\hline $\begin{array}{l}\text { a. Collembola groups are further subdivided into epigeous (pigmented, seeing) and hypogeous (non-pigmented, } \\
\text { blind) life forms. }\end{array}$ \\
\hline
\end{tabular}

\section{B-3.3.5 Data Report}

The data will be returned as a report summarizing the counts of each major group, as described above, with tallies taken separately for each group for each disc. The report will be submitted along with the fauna samples. Spent soil and litter contents of each disc will be returned to the site.

\section{B-3.4 Histopathology and Body and Organ Weight}

Tissues will be collected from small mammals for chemical and radiological analysis, genetics, and histopathology. On the last day of small-mammal population surveys (see Section B-3.1.3), at least three deer mice in each sampling plot will be retained as a single composite sample. Deer mice will be humanely harvested by cervical dislocation or asphyxiation with carbon dioxide gas before transport to the laboratory. Animals should be removed from traps one at a time, so that specimens are not misidentified. Processing should take place as soon as possible after trap checks to reduce potential degradation of the specimen. The deer mice will be weighed in the laboratory to the nearest $0.01 \mathrm{~g}$.

A ventral incision will be made with a clean scalpel blade. The liver and kidney will be weighed to the nearest $0.01 \mathrm{~g}$. Small slices of each will be placed in $10 \%$ buffered formalin and the rest will be returned to the carcass. This solution is potentially carcinogenic and should be handled with caution, as detailed on the material safety data sheet. The jar will be labeled with appropriate sample information (time, date, sample identification number, and ear tag number).

The carcasses forming the single composite sample will be placed in a sealable plastic bag, placed inside another bag, and then labeled for contaminant analysis. Chain-of-custody forms will be completed. 
The removal of the kidney and liver may slightly reduce apparent concentrations. Estimated loss in concentration is as shown in Equation (B-6):

$\mathrm{mg} / \mathrm{kg} \mathrm{WB} * \mathrm{~kg} \mathrm{WB}+\mathrm{mg} / \mathrm{kg} \mathrm{L} * \mathrm{~kg} \mathrm{~L}+\mathrm{mg} / \mathrm{kg} \mathrm{k} * \mathrm{~kg} \mathrm{k}$

where:

$$
\begin{aligned}
& \mathrm{mg} / \mathrm{kg} \mathrm{WB}=\text { concentration in whole body } \\
& \mathrm{mg} / \mathrm{kg} \mathrm{L}=\text { concentration in liver (estimated) } \\
& \mathrm{mg} / \mathrm{kg} \mathrm{k}=\text { concentration in kidney (estimated). }
\end{aligned}
$$

A bioaccumulation factor from the literature will be used to estimate the fraction lost to histopathology. Although the bioaccumulation factor introduces uncertainty into the assessment, the liver and kidney tend to concentrate metals and might exhibit cellular changes for evaluation of effects from exposure. If effects are determined to be present, a selected study will be performed to further characterize this problem, or the sampling approach will be modified appropriately.

\section{B-4. AQUATIC ECOSYSTEM CHARACTERIZATION}

Chilly Slough was selected as the aquatic reference area.

\section{B-4.1 Sediment and Surface Water Analytical Sampling}

Sediment and surface water samples will be obtained from the reference area and from the waste ponds at the Materials and Fuel Complex. The data will be used to predict health effects and exposure in aquatic receptors. Five grab samples of each medium will be collected from the pond in locations determined in the field. The locations will be surveyed using a GPS unit.

\section{B-4.2 Biota Analytical and Effects Sampling}

If appropriate aquatic receptors (tadpoles or frogs) are identified and present, they will be collected and identified to the lowest taxonomic level possible. Sixty grams is required for all analytical work. Five samples will be collected from the pond.

\section{B-5. REFERENCES}

Barrett, R. H., 1983, "Smoked Aluminum Track Plots for Determining Furbearer Distributions and Relative Abundance," California Fish and Game, 69:188-190.

Belthoff, J. R. and E. A. Ellsworth, 1999, Breeding Bird Surveys at the Idaho National Engineering and Environmental Laboratory, Environmental Science and Research Foundation, September 1999.

Bystrak, D., 1981, “The North American Breeding Bird Survey,” C. J. Ralph and J. Scott, Eds., Estimating the Number of Terrestrial Birds, Stud. Avian Biol. 6, pp. 34-41.

Coleman, D. C., J. M. Blair, E. T. Elliott, and D. H. Wall, 1999, "Soil Invertebrates," Standard Soil Methods for Long-Term Ecological Research, New York: Oxford University Press, pp. 349-377. 
INEEL, 2004, Long-Term Ecological Monitoring Plan for the Idaho National Engineering and Environmental Laboratory, INEEL/EXT-02-01191, Rev. 1, Idaho National Engineering and Environmental Laboratory, January 2004.

MCP-1194, 2006, “Logbook Practices for ICP CERCLA and Removal Action Projects,” Rev. 3, Idaho National Laboratory, Idaho Cleanup Project, September 2006.

Robbins, C. S., D. Bystrak, and P. H. Geissler, 1986, "The Breeding Bird Survey: Its First Fifteen Years," 1965-1979, USFWS Res. Pub. 157, Washington, DC.

Robertson, G. P., D. C. Coleman, C. S. Bledsoe, and P. Sollins, eds., 1999, Standard Soil Methods for Long-Term Ecological Research, New York: Oxford University Press, pp. 349-377.

TPR-145, 2006, "Biotic and Proximal Soil Sampling,” Rev. 4, Idaho National Laboratory, Idaho Cleanup Project, May 2006.

USGS, 2006, The North American Breeding Bird Survey, http://www.mbr-pwrc.usgs.gov/bbs/genintro.html, U.S. Geological Survey, website visited January 29, 2007. 
Attachment 1

Survey Forms and Data Sheets 
B-20 
Date

Weather

Conditions

Cloud Cover

\begin{tabular}{|c|c|c|c|c|c|c|c|c|c|c|}
\hline Location & Plot \# & $\begin{array}{c}\text { Nearest } \\
\text { Trap \# } \\
\end{array}$ & Species & $\begin{array}{c}\text { Time } \\
(24 \mathrm{hr})\end{array}$ & $\begin{array}{c}\text { Air Temp } \\
\left({ }^{\circ} \mathrm{C}\right)\end{array}$ & Sex & $\begin{array}{c}\text { Weight } \\
\text { (g) }\end{array}$ & $\begin{array}{l}S V L^{a} \\
(\mathrm{~mm})\end{array}$ & $\begin{array}{c}\text { Tail } \\
(\mathrm{mm}) \\
\end{array}$ & Habitat/Comments \\
\hline & & & & & & & & & & \\
\hline & & & & & & & & & & \\
\hline & & & & & & & & & & \\
\hline & & & & & & & & & & \\
\hline & & & & & & & & & & \\
\hline & & & & & & & & & & \\
\hline & & & & & & & & & & \\
\hline & & & & & & & & & & \\
\hline & & & & & & & & & & \\
\hline & & & & & & & & & & \\
\hline & & & & & & & & & & \\
\hline & & & & & & & & & & \\
\hline & & & & & & & & & & \\
\hline & & & & & & & & & & \\
\hline
\end{tabular}

a. Snout-vent length

\section{Reptile Data Sheet}

Page Number 


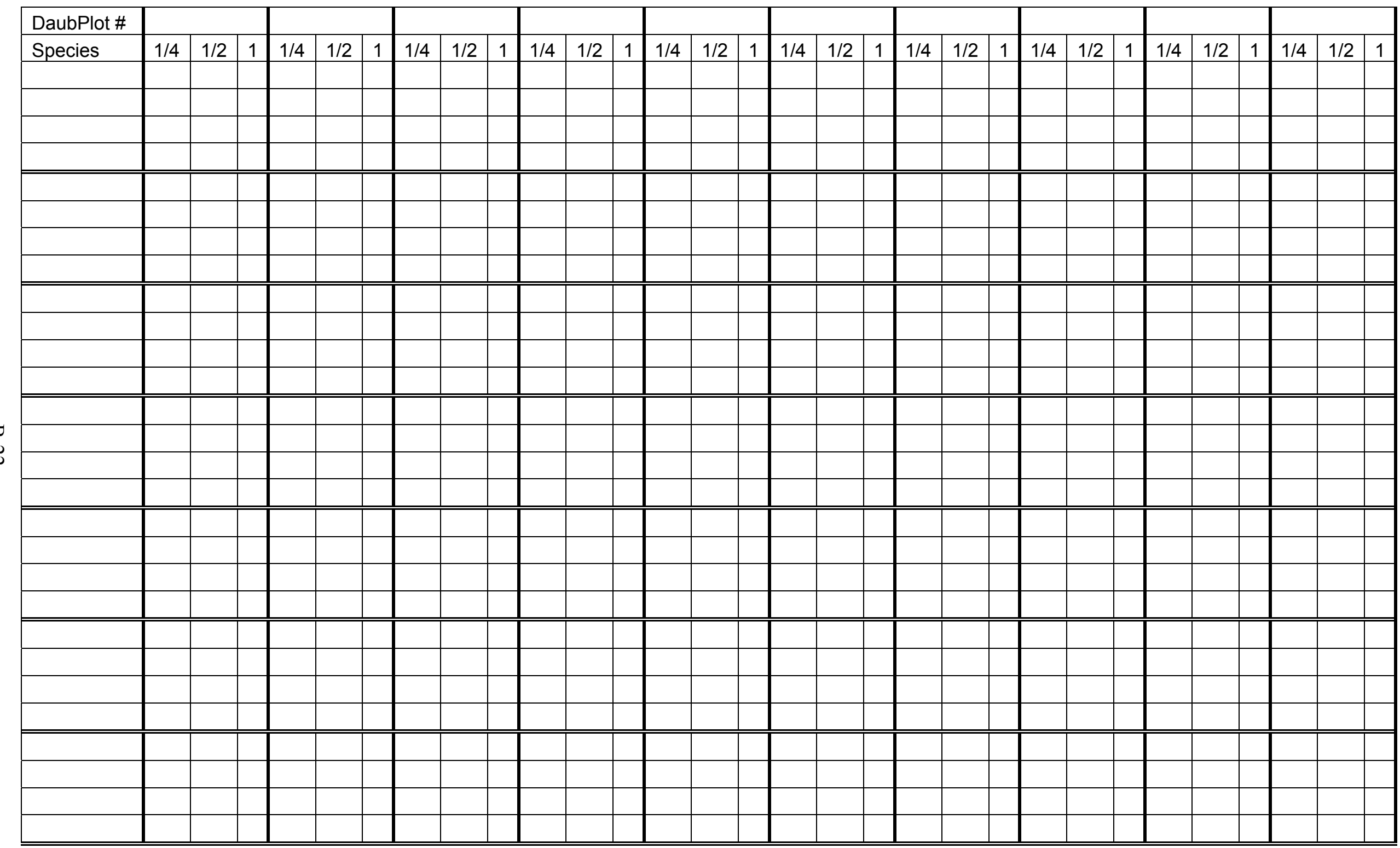


Recorder's Name

Trapper's Name

\section{Small Mammal Data Sheet}

Date

Location

Plot \#

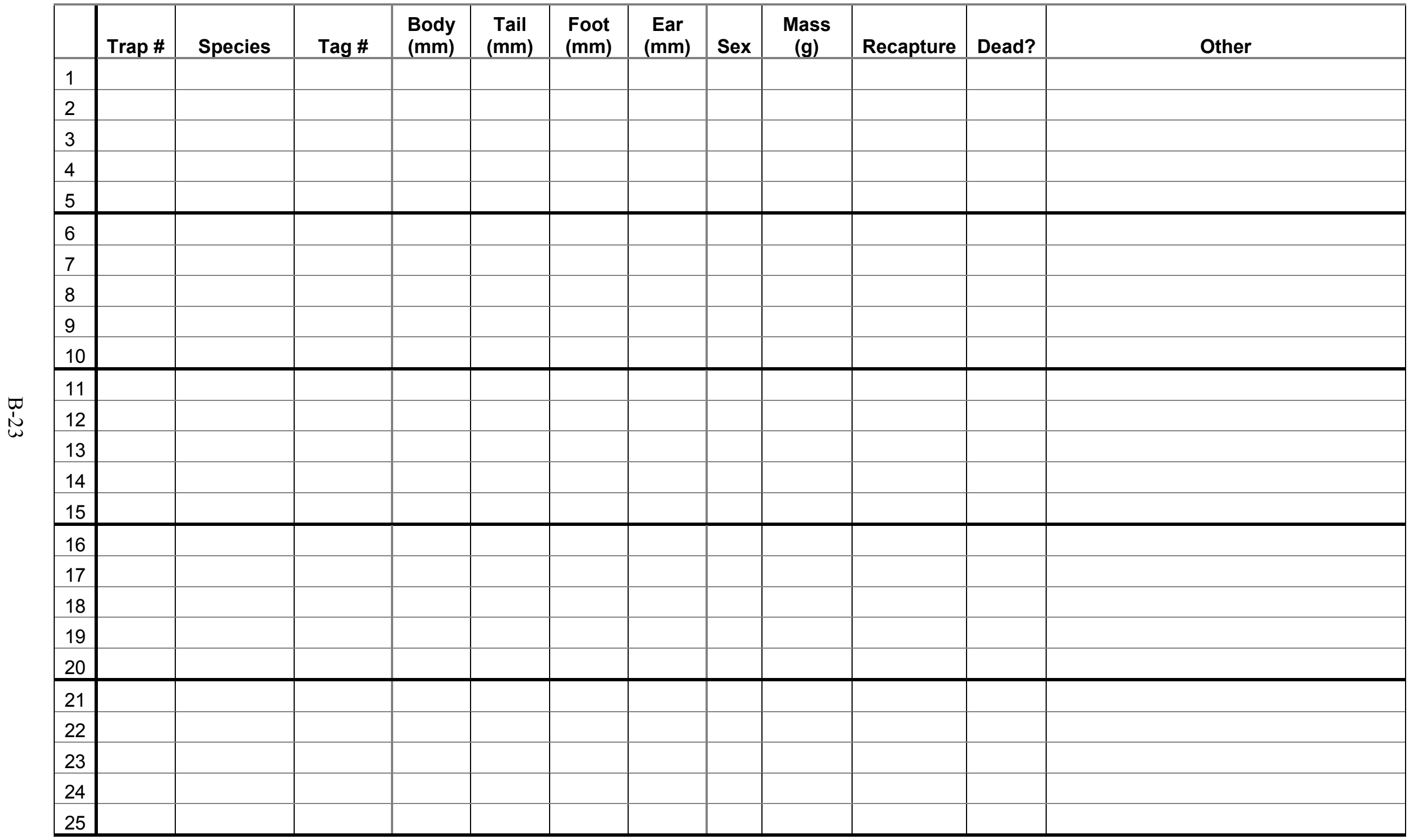




Observer:
\begin{tabular}{|l|l|l|l|l|l|l|l|l|}
\hline Date & Location & Nest ID & Species & \# of Eggs & \# of Young & Nest Site Description & Comments \\
\hline & & & & & & & & \\
\hline & & & & & & & \\
\hline & & & & & & & \\
\hline & & & & & & & \\
\hline & & & & & & & \\
\hline & & & & & & & \\
\hline & & & & & & & \\
\hline & & & & & & & \\
\hline & & & & & & & \\
\hline & & & & & & & \\
\hline & & & & & & & \\
\hline & & & & & & & \\
\hline & & & & & & & \\
\hline & & & & & & & \\
\hline & & & & & & & \\
\hline & & & & & & & \\
\hline & & & & & & & \\
\hline & & & & & & & \\
\hline
\end{tabular}


Temperature:

Observer:

Date:
Avian Point Count Data Form

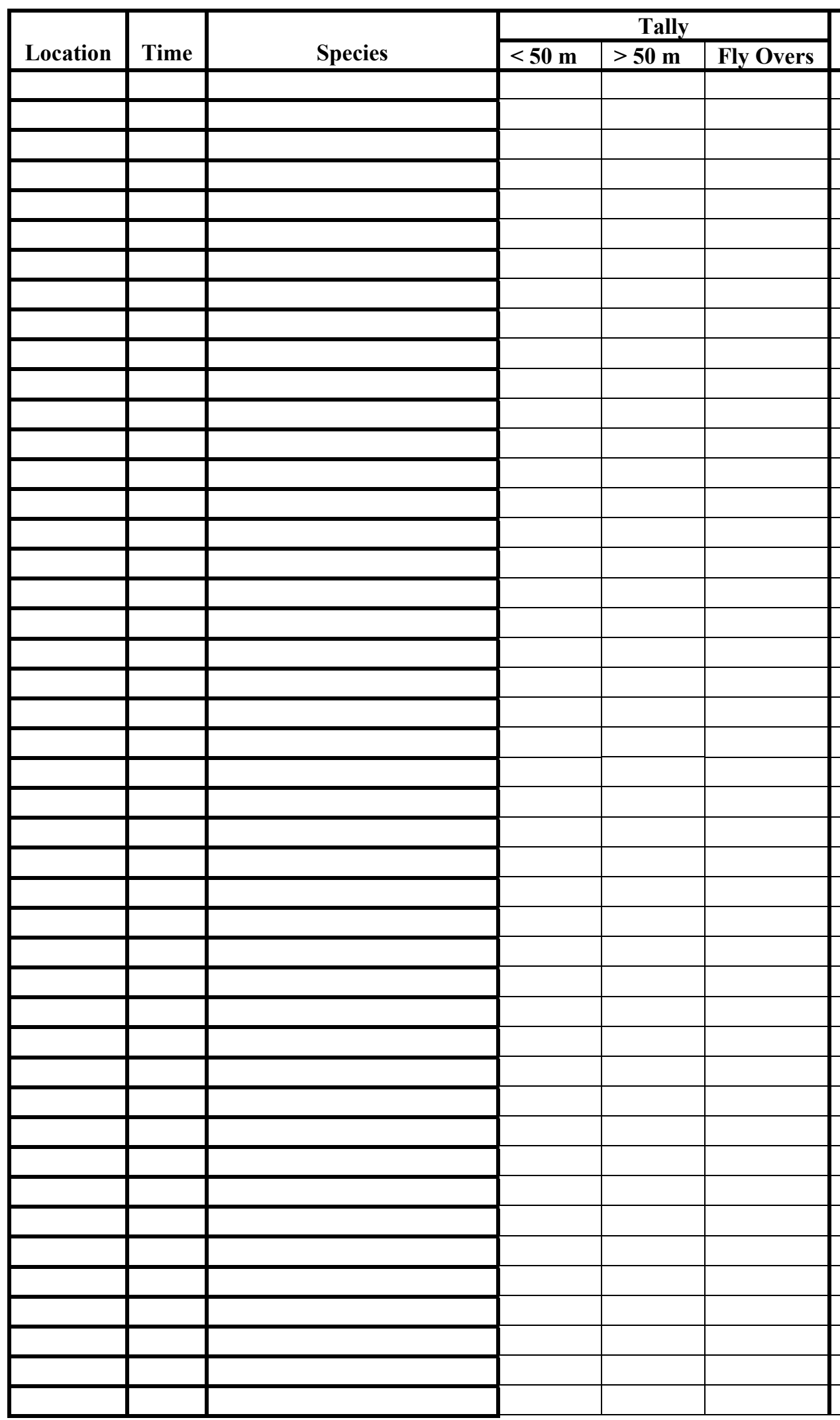

Wind:

Cloud Cover:

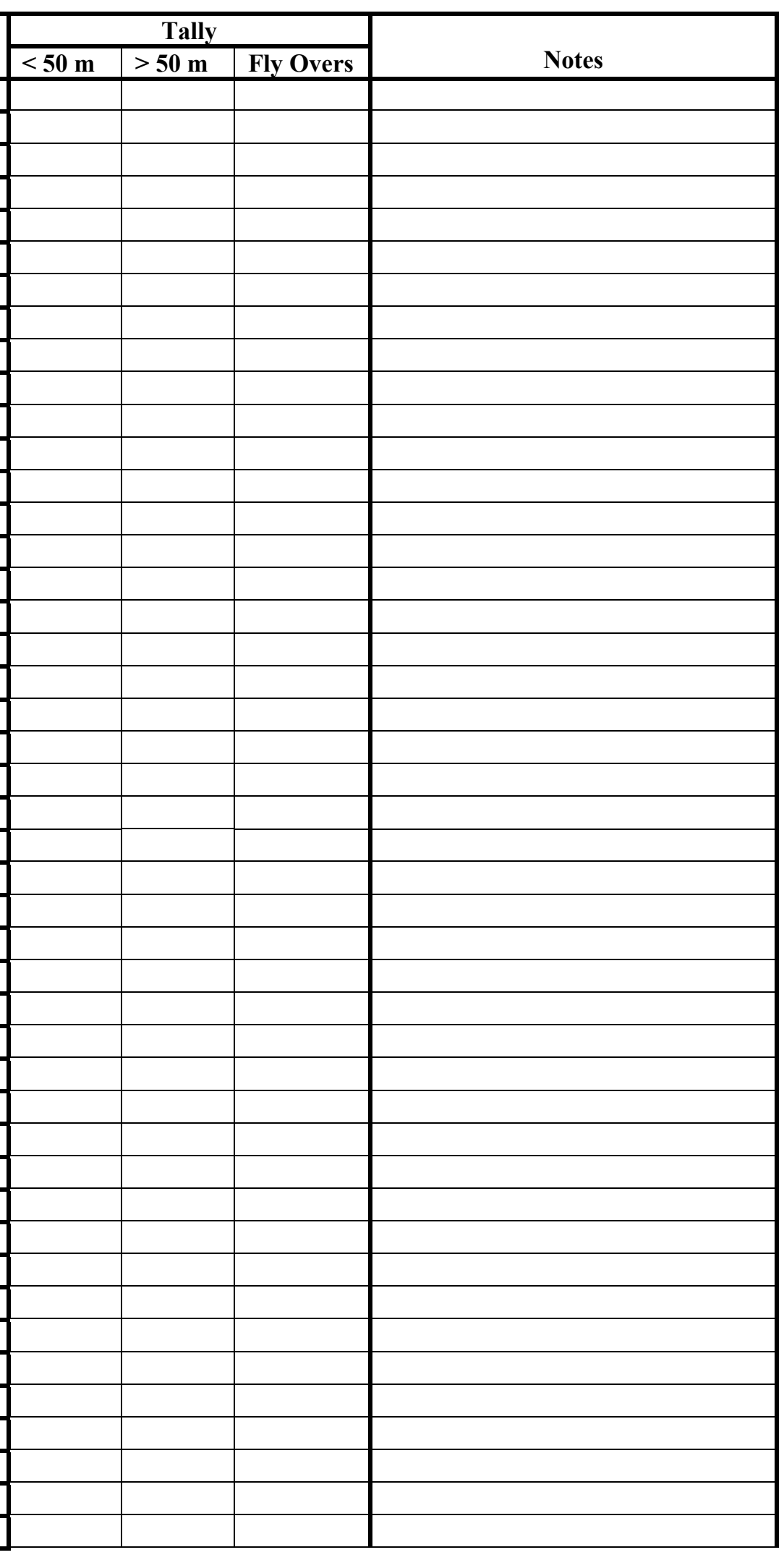

